\title{
A ATIVIDADE ARTESANAL COM FIBRA DE BANANEIRA EM COMUNIDADES QUILOMBOLAS DO VALE DO RIBEIRA (SP).
}

KATIA MARIA PACHECO SANTOS

Dissertação apresentada à Escola Superior de Agricultura "Luiz de Queiroz", Universidade de São Paulo, para obtenção do título de mestre em Ecologia de Agroecossistemas.

PIRACICABA

Estado de São Paulo - Brasil Março - 2005 


\section{A ATIVIDADE ARTESANAL COM FIBRA DE BANANEIRA EM COMUNIDADES QUILOMBOLAS DO VALE DO RIBEIRA (SP)}

\section{KATIA MARIA PACHECO SANTOS}

Engenheiro Agrônomo

Orientadora: Profa. Dra. MARIA ELISA DE PAULA EDUARDO GARAVELLO

Dissertação apresentada à Escola Superior de Agricultura "Luiz de Queiroz", Universidade de São Paulo, para obtenção do título de Mestre Ecologia de Agroecossistemas. 
Dados Internacionais de Catalogação na Publicação (CIP) DIVISÃO DE BIBLIOTECA E DOCUMENTAÇÃO - ESALQ/USP

Santos, Katia Maria Pacheco dos

A atividade artesanal com fibra de bananeira em comunidades quilombolas do Vale do Ribeira (SP) / Katia Maria Pacheco dos Santos. - - Piracicaba, 2005.

99 p. : il.

Dissertação (mestrado) - - Escola Superior de Agricultura Luiz de Queiroz, 2005.

Bibliografia.

1. Artesanato 2. Fibra de bananeira 3. Quilombos - Comunidades 4. Renda familiar 5. Resíduos agrícolas 6. Vale do Ribeira I. Título

CDD 677.54

"Permitida a cópia total ou parcial deste documento, desde que citada a fonte - O autor" 


\section{DEDICATÓRIA}

Dedico este trabalho a memória de minha querida mãe Eleusina Pacheco, pela guerreira que sempre foi e por ensinar-me a ter fé. Mãe, obrigada por ser meu exemplo de Ser Humano, meu anjo da guarda de todos os momentos e em especial, durante esta caminhada. 


\section{AGRADECIMENTOS}

Durante a realização deste trabalho fui presenteada com várias sugestões de pessoas que fazem parte de alguns capítulos da minha história, em singulares momentos, e tornaram-se co-autores desta dissertação. Reservo somente para mim os erros deste trabalho, mas quero dividir com todos os amigos o mérito dele.

Às artesãs de Sapatu, André Lopes e Ivaporunduva, sem as quais esta dissertação não seria possível. Meu obrigada em especial à Sônia, D. Esperança, D. Antônia, D. Araci, D Zilda, Vera, Paufão, Sr. Pedro, Olavinho e Ditão. Enfim, à todos os quilombolas que tive a imensa honra de conhecer nesse lugar tão especial que é o Vale... a beira do Ribeira.

À minha querida amiga Adriana Felipim, pelas incansáveis contribuições, correções, palpites. Obrigada Dri, por tudo!

À Raquel Pasinato, pela silenciosa e enorme ajuda. Obrigada amiga!

À tia e amiga Diana Pacheco, que com sua alegria de viver e sabedoria, sempre me ajudou na caminhada da vida.

À querida Silvia Molina, pelos incentivos, paciência e sobretudo, pelo exemplo de profissional e ser fumano que é. Obrigada Sifvia!

À Lilian Abram, pela imprescindível ajuda nos momentos finais dessa dissertação e pelos vários momentos agradáveis que passamos juntas em Macapá.

Aos amigos de Macapá: Sueli, Lili, Paulo, Igor, Gisele, Claudinha, Henrique e também à todos os Wajãpi do Amapari, pela paciência e força no nosso dia-a-dia.

Ao rio Amazonas e sua maravilhosa 6risa, que foi por muitas vezes meu maior alento nos últimos sete meses de dissertação.

Ao pessoal do ITESP de Pariqüera-Açu e Eldorado, em especial, ao Renato "Cabelo" e a Gabriela. 
Aos amigos do litoral e Vale, Mário $\mathcal{N} u n e s$ e a Isadora, Ritinha, Joaquim de Marco Neto, Alexandre Aguiar, Otto e Deidy... pelos momentos de alegria que foram fundamentais na minha vida.

Aos amigos que tem sua cadeira cativa no meu coração, Wirifran, Claúdio de Olinda, Milena, Márcia, ao pessoal da vila da pós-graduação da ESALQ. E a querida Katia Nachiluk.

Ao amigo Juan Águila, pela preciosa companfia e maturidade.

À amiga Eliana Rodrigues, por me incentivar a fazer esse mestrado e pelas precisas contribuições durante esta caminhada.

Ao professor Caron, pelas contribuiçôes pertinentes, pelas conversas norteadoras e em especial, pelo mestre e ser humano que é.

À minha orientadora Maria Elisa, pela confiança, amizade, ensinamentos e conquistas que tivemos juntas durante todo meu tempo de ESALQ.

Às secretárias do PPGI, Regina e Eliana, e a CAPES, pelos meses de bolsa de estudo.

Enfim, à todos os meus amigos que vejo e considero "anjos materializados" e à todos os outros amigos que não vejo mas os sinto, e os chamo de "anjos da guarda".

Meus agradecimentos eternos a minha mãe querida, Eleusina Pacheco, por toda fortaleza de ser humano, minha maior admiradora e torcedora, que se foi deste mundo antes mesmo de ter eu a certeza que concluiria este trabalho. Que pena, mãe, você não poder estar aqui para lêt-lo. De tudo, o mais difíil têm sido aprender a viver sem poder ouvir a sua voz serena à me impulsionar a seguir sempre em frente.

E por fim, à Deus, pela Dom da vida e pelas conquistas que tem me proporcionado. Obrigada Pai! 


\section{Vida}

$\mathcal{N} a$ dúvida, faça.

O risco faz parte.

A graça está

em tentar,

em vez de sentar e assistir;

o mundo está

em esticar-se todo para atingir;

o mundo está

no desafio da interrogação.

E porque não?

Entre na festa,

arranque a capa,

morda a maçã.

Desate o cinto

para voar livre pelo amanhã,

ainda que ele seja um Cabirinto.

deixe o ID rolar

Nesta arte viva de arriscar,

cônscio e devoto.

Pois que viver

não é entrar no mar onde dá pé,

mas mergulhar com fé no maremoto

(Flora Figueiredo) 


\section{SUMÁRIO}

Página

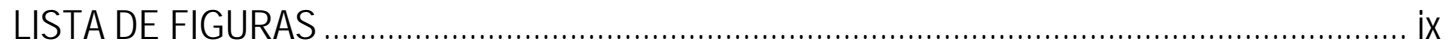

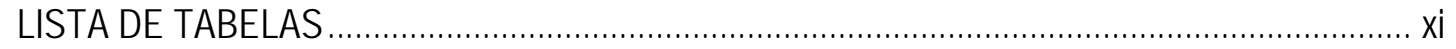

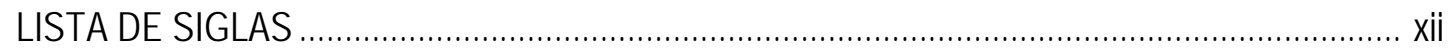

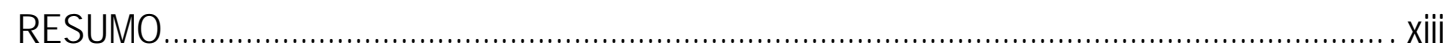

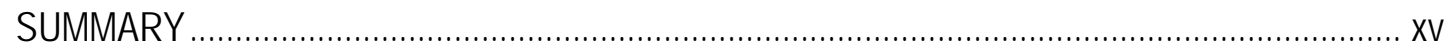

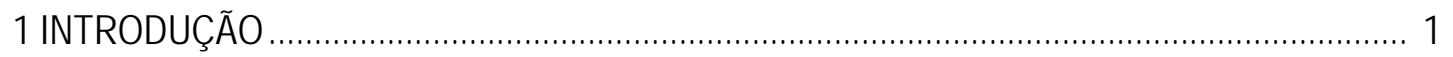

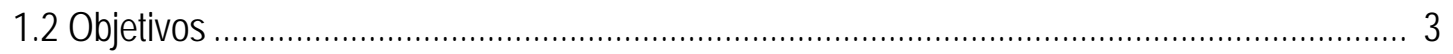

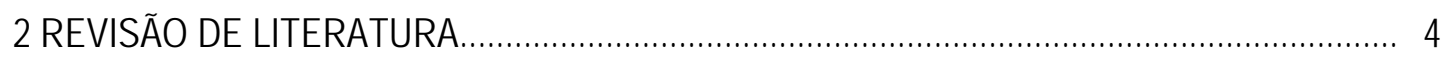

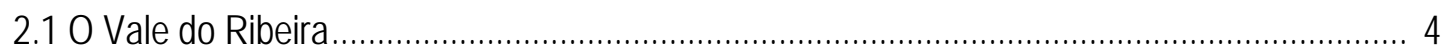

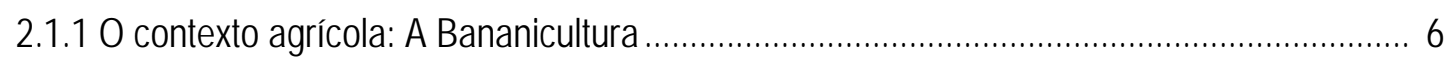

2.1.2 O contexto social: As Comunidades Quilombolas ................................................................ 7

2.2 Os planos de desenvolvimento para o Vale do Ribeira ........................................................ 11

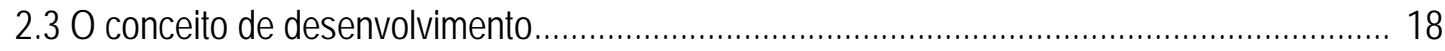

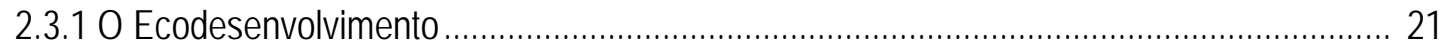

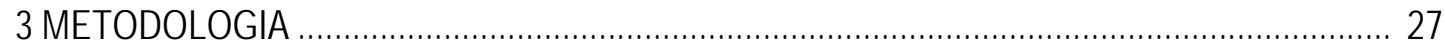

3.1 Os caminhos da pesquisa: as técnicas adotadas para a coleta e análise dos dados......... 27

3.2 Descrição das três comunidades envolvidas na pesquisa................................................... 30

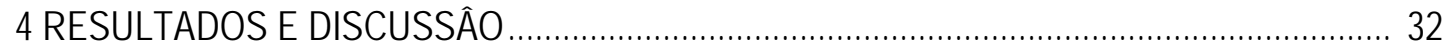

4.1 Histórico de implantação da atividade nas comunidades estudadas .................................. 32

4.1.1 A assimilação da técnica ...................................................................................... 41

4.2 A questão ambiental e 0 artesanato ............................................................................ 52

4.2.1 0 modo de vida das comunidades e as restrições ambientais.......................................... 52 


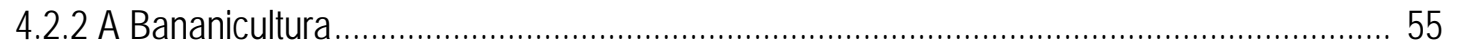

4.2.30s resíduos da bananicultura na atividade artesanal ...................................................... 59

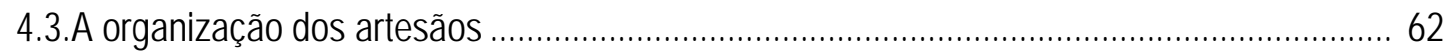

4.3.1 A relação de gênero e os espaços da confecção artesanal ............................................. 68

$4.4 \mathrm{O}$ artesanato como atividade econômica ....................................................................... 72

4.4.1 0 artesanato e 0 turismo na comunidade de Ivaporunduva ............................................. 81

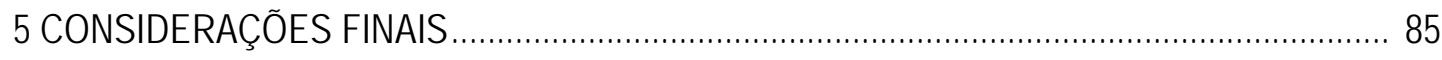

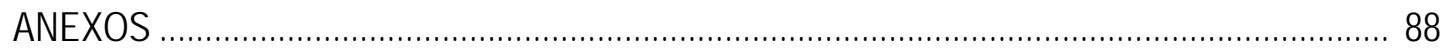

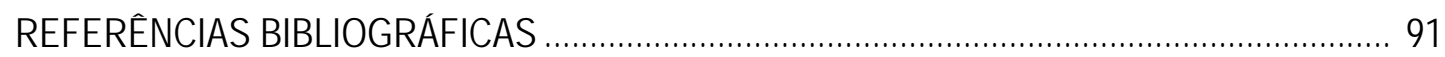




\section{LISTA DE FIGURAS}

Página

1 Localização do Vale do Ribeira no Estado de São Paulo. 4

2 Primeiro curso ministrado em Ivaporunduva ........................................................................ 34

3 Artesã de Ivaporunduva durante o primeiro curso montando 0 tear......................................... 35

4 Primeiro curso ministrado na comunidade de Sapatu.................................................................... 36

5 Casa do artesão construída no Parque Estadual de Jacupiranga: Caverna do Diabo ............ 37

6 Construção destinada aos artesão de André Lopes .......................................................... 38

7 Construção destinada aos artesãos de Sapatu...................................................................... 38

8 Casa do Artesanato de Ivaporunduva ........................................................................ 38

9 Tear de pente liço de cavalete e tear de mesa no chão ........................................................ 42

10 Corte do tronco de bananeira ............................................................................................ 43

11 troncos de bananeira e bainhas sendo separadas por um artesão de André Lopes ............ 44

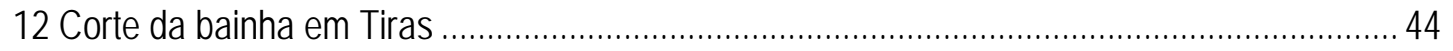

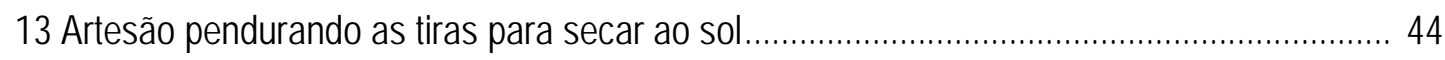

14 Armazenagem das tiras de fibras de bananeira por artesã de Sapatu.................................. 45

15 Artesãs de Sapatu com as fibras da palha de bananeira já secas e prontas para tecer ....... 45

16 Artesã de Ivaporunduva com peça pronta............................................................................. 46 


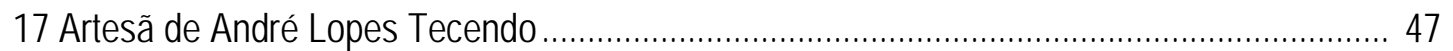

18 Artesã de Sapatu fazendo trança com tiras de palha de bananeira ...................................... 47

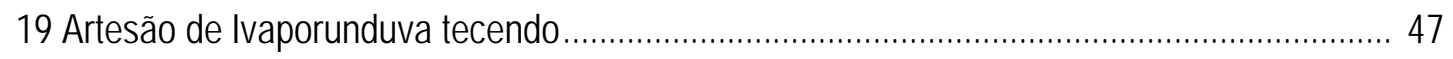

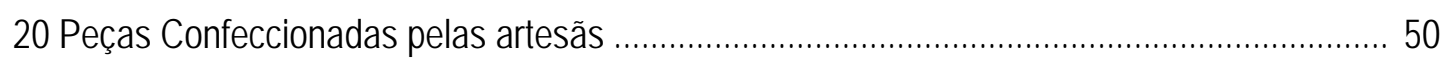

21 Bolsa de fibra de bananeira com detalhes coloridos........................................................... 50

22 Peças: jogo americano, tapete e caminho de mesa ........................................................... 51

23 Peças de fibra de bananeira e de taquara ....................................................................... 51

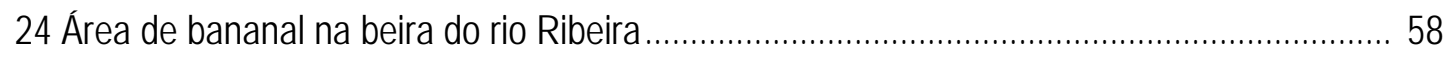

25 Venda do artesanato na beira da estrada de acesso à Caverna do Diabo ............................ 82 


\section{LISTA DE TABELAS}

Página

1 Número de participantes dos cursos de capacitação nos anos de 1997 e 1998.

2 Número de participantes no curso de capacitação de 2000.

3 Quantidade de homens e mulheres capacitados nos cursos e a quantidade de pessoas

que atualmente fazem 0 artesanato com fibra de bananeira.

4 Tipos de peças artesanais produzidas com a fibra de bananeira, seus acessórios e corantes naturais 49

5 Dados relativos ao uso da terra nas comunidades no ano de 2002. 57

6 Os colaboradores externos envolvidos com a atividade artesanal de fibra de bananeira e os seus papéis.

7 Quantidade de pessoas que declaram possuir renda e a média mensal destes antes e depois do curso de capacitação do artesanato com fibra de bananeira de 1998 74

8 Preço das peças mais vendidas pelos artesãos nas comunidades 77

9 Caixa financeiro do fundo do artesanato do grupo de Ivaporunduva no ano 2003. 78 


\section{LISTA DE SIGLAS}

(CPT); Comissão da Pastoral da Terra;

(CODIVAR) Consórcio de Desenvolvimento Intermunicipal do Vale do Ribeira CEDAVAL).Centro de Desenvolvimento Agrícola do Vale (

ESALQ - Escola Superior de Agricultura "Luiz de Queiroz

FF - Fundação Florestal

IF - Instituto Florestal

FAPESP - .: Fundação de Amparo à Pesquisa do Estado de SP

(FAC); Fraterno Auxílio Cristão

(ISA), Instituto Sócioambiental

ITESP - Instituto de Terras do Estado de São Paulo

MOAB Movimento dos Ameaçados por Barragens

PLADEL),Plano de Desenvolvimento do Litoral

SUTACO - Superintendência do Trabalho Artesanal de Comunidades

SEBRAE Serviço Brasileiro de Apoio às Micro e Pequenas Empresas

SMA)Secretaria do Meio Ambiente do Estado de São Paulo

SUDELPA).Superintendência do Desenvolvimento do Litoral Paulista

UC - Unidade de Conservação

USP Universidade de São Paulo 


\title{
A ATIVIDADE ARTESANAL COM FIBRA DE BANANEIRA EM COMUNIDADES QUILOMBOLAS DO VALE DO RIBEIRA (SP).
}

\author{
Autora: KATIA MARIA PACHECO DOS SANTOS \\ Orientadora: Profa. Dra. MARIA ELISA DE PAULA EDUARDO GARAVELLO
}

\section{RESUMO}

O presente estudo trata da descrição e análise da atividade artesanal com fibra de bananeira praticada pelas comunidades quilombolas de Ivaporunduva, André Lopes e Sapatu, município de Eldorado, região do Vale do Ribeira, tendo como referencial teórico o conceito de ecodesenvolvimento proposto por Sachs (1980). A atividade artesanal com fibra de bananeira foi iniciada no ano de 1997, através de um projeto de pesquisa executado pela Escola Superior de Agricultura "Luiz de Queiroz" (ESALQ) - Universidade São Paulo (USP): "Projeto de Aproveitamento de Resíduos da Agroindústria da Banana no Vale do Ribeira, SP" cujo objetivo consistia em realizar estudos que resultassem em alternativas economicamente viáveis para 0 aproveitamento dos resíduos da bananicultura na região. Desde de então, a atividade artesanal com fibra de bananeira vêm sendo praticada por integrantes das comunidades referidas. Para coletas de dados foram utilizadas técnicas comumente trabalhadas pelas nas ciências sociais como: observação participante, entrevistas informais não-estruturadas e semi-estruturadas com os artesãos envolvidos e com representantes de Instituições governamentais e não governamentais atuantes no processo. Verificou-se neste trabalho a contribuição da atividade artesanal na valorização da mulher, a compatibilidade da tecnologia repassada com os contextos social e ambiental locais, o aproveitamento dos recursos locais disponíveis e o papel dessa 
atividade na economia familiar. Analisando o processo de geração, adoção e disseminação da atividade artesanal com fibra de bananeira e seus resultados nas comunidades conclui-se que esta atividade: (1) representa hoje um significativo complemento na renda familiar dos artesãos que a praticam; (2) é praticada em conformidade com a organização sócio-cultural local, (3) não gera impacto ambiental negativo e (4) dispõe, em quantidade significativa, da matéria prima necessária para realização da atividade. Portanto, sua prática é compatível com os preceitos do ecodensenvolvimento. 


\section{ACTIVITIES IN HANDCRAFT FROM BANANA PLANT FIBRE IN QUILOMBOLA COMMUNITIES IN THE RIBEIRA VALLEY (SÃO PAULO STATE).}

Author: KATIA MARIA PACHECO SANTOS

Adviser: Prof. Dra. MARIA ELISA DE PAULA EDUARDO GARAVELLO

\section{SUMMARY}

This study focuses on a description and analysis of activities in handcraft from banana plant fibre in practice among Quilombola communities in Ivaporunduva, André Lopes, and Sapatu, municipality of Eldorado, in the region of the Ribeira Valley, with the concept of ecodevelopment proposed by Sachs (1980) as theoretical reference. Activities in handcraft from banana plant fibre began in 1997 through a research project carried out by the Escola Superior de Agricultura "Luiz de Queiroz" (ESALQ) - USP - the University of São Paulo: "Project for Use of Agroindustrial Residue from Banana in the Ribeira Valley, SP", the objective of which consisted in carrying out studies that would result in economically viable alternatives for the use of the residues of banana crops in the region. Activities in handcraft have been in practice by members of these same communities as from then. Data were collected by means of techniques in common use in social sciences such as: participant observation, non-structured and semi-structured informal interviews with the craftsmen involved and with representatives of government and non-government institutions active in the process. The study records the contribution of handcraft activities in enhancing the role played by women, in technological compatibility conveyed within local social and environmental contexts, in the use of local resources available, and in the role of these 
activities in terms of family economy. As a result of analyzing the process of generating, adopting, and disseminating handcraft activities from banana plant fibre and the results in the communities, it can be concluded that these same handcraft activities: (1) today, account for a significant supplement to the family income for the craftsmen who engage in handcraft; (2) are in practice in accordance with local socio-cultural organization; (3) do not generate a negative impact on the environment and (4) have resort to a significant quantity of the raw material necessary to carry out these same activities. This handcraft activity is, therefore, compatible with the precepts of ecodevelopment. 


\section{INTRODUÇÃO}

Há muito, a região do Vale do Ribeira é conhecida por apresentar os mais baixos indicadores sociais do Estado de São Paulo.

Do final da década de 50 até início da década de 80 , as políticas públicas voltadas para 0 desenvolvimento do Vale do Ribeira raramente estavam direcionadas para as populações de baixa renda e para as especificidades da região, ou seja, as particularidades ambientais e sociais existentes. Os resultados das ações implantadas nesse período foram a intensa concentração de renda e o agravamento dos desequilíbrios ambientais e sociais regionais (Instituto da Cidadania, 1996; Resende, 2002).

A partir de 1982 que as ações públicas (caracterizadas como promotoras do "desenvolvimento") passaram a considerar, de modo mais efetivo, as particularidades da região. Foi também neste período que se intensificaram os movimentos ambientalistas no Brasil em prol da efetiva implantação das Unidades de Conservação, do reconhecimento do bioma Mata Atlântica, da importância de se criar novas políticas públicas voltadas à conservação e ao uso racional dos recursos e da necessidade de pensar o "desenvolvimento" de forma diferenciada.

Ainda que no Brasil, o marco para essas questões tenha sido a década de 80 , a formulação de estratégias para construção de outro sistema de desenvolvimento já vinha sendo tratada há mais de uma década nos países de primeiro mundo. No ano de 1973, durante a Conferência de Estocolmo, sobre Meio Ambiente, uma nova proposta que se baseava na integração dos aspectos sócio-culturais, econômicos e ambientais, foi intitulado como "ecodesenvolvimento" (Almeida et al, 1999; Soares, 1999 e Vieira, 2001).

O conceito de ecodesenvolvimento foi fundamentado e disseminado por Sachs (1980) como uma estratégia para se promover a autonomia das populações e estimular novas formas de crescimento econômico que priorizem 0 potencial dos recursos 
naturais e sociais de cada local. O autor defendia ser fundamental o desenvolvimento de tecnologias apropriadas que permitam absorver o melhor da especificidade e da variabilidade, tanto humana como naturais, de cada ecossistema (local ou regional) de forma particular (Sachs, 1980).

No final da década de 80 e início da década de 90, programas e ações propostos por instituições públicas e privadas (que buscavam conjugar o crescimento econômico, a geração de empregos e a proteção adequada do meio ambiente), já adotaram esses fundamentos.

Um exemplo desta iniciativa na região do Vale do Ribeira, Estado de São Paulo foi a implantação do "Projeto de Aproveitamento de Resíduos da Agroindústria da Banana no Vale do Ribeira, SP", com objetivo de realizar estudos que resultassem em propostas economicamente viáveis e que viessem contribuir para a geração de empregos na região. Esse Projeto, iniciado no ano de 1991, foi desenvolvido pela Escola Superior de Agricultura "Luiz de Queiroz" (ESALQ), a Universidade de São Paulo (USP), por solicitação do Consórcio de Desenvolvimento Intermunicipal do Vale do Ribeira (CODIVAR) e financiado pela Secretaria de Ciência, Tecnologia e Desenvolvimento Econômico do Estado de São Paulo.

Alguns resultados práticos desse projeto podem ser vistos até os dias de hoje no Vale do Ribeira. Algumas comunidades quilombolas da região por exemplo, estão envolvidas no aproveitamento dos resíduos de bananeiras para confecção de artesanato e têm nessa atividade uma fonte de renda. Tal fato nos leva a crer que essa intervenção proporcionou às pessoas envolvidas no Projeto uma alternativa econômica, mas esta pode, de fato, ser considerada "viável"? Essa ação junto as comunidade quilombolas considerou as peculiaridades sócioculturais da população, o potencial natural dos recursos existentes ou os impactos sociais, econômicos e ambientais desta atividade? É no sentido de analisar essas questões que se direcionou o presente trabalho

Conciliar a busca por alternativas econômicas viáveis, com o uso racional dos recursos naturais, a redução das desigualdades sociais, a garantia de acesso de todos nos processos de tomada de decisões e a preservação da diversidade e identidade cultural, são os preceitos básicos do ecodesenvolvimento.

O referencial teórico adotado para nortear a analise da atividade artesanal implantada pelo "Projeto de Aproveitamento de Resíduos da Agroindústria da Banana no Vale do Ribeira, 
SP", nas comunidades quilombolas de Ivaporunduva, André Lopes e Sapatu, situadas na cidade de Eldorado, região do Vale, foi o do conceito de ecodesenvolvimento.

\subsection{Objetivos}

\section{Geral}

Descrever e analisar a atividade artesanal com fibra de bananeira, proposta pelo "Projeto de Aproveitamento de Resíduos da Agroindústria da Bananicultura no Vale do Ribeira - SP", nas comunidades quilombolas de Ivaporunduva, André Lopes e Sapatu.

\section{Específicos}

1. mapear a rede social ${ }^{1}$ envolvida com a atividade artesanal com fibra de bananeira nas comunidades foco;

2. verificar se houve mudanças com relação ao incremento de renda para artesãos envolvidos com esta atividade;

3. identificar, em conjunto com os artesãos das comunidades, os fatores limitantes e potenciais da atividade artesanal com fibra de bananeira

4. verificar se 0 artesanato com fibra de bananeira provocou mudanças ambientais dentro do espaço territorial de Ivaporunduva, André Lopes e Sapatu.

\footnotetext{
1 Definimos aqui como rede social os envolvidos com o artesanato de fibra de bananeira, sejam eles os próprios artesãos como outros indivíduos das comunidades foco (colaboradores primários), pessoas da ESALQ envolvidas com ao processo (colaboradores internos) e os indivíduos de instituições governamentais e não governamentais e sociedade civil que de algum modo fazem parte desta rede (os colaboradores externos).
} 


\section{REVISÃO DE LITERATURA}

\subsection{Vale do Ribeira}

Situada no sul do estado de São Paulo, a região do Vale do Ribeira é composta por 23 municípios que cobrem uma área de 15.480 quilômetros quadrados e por uma população com cerca de 411.500 habitantes (Born \& Talocchi, 2002). Alguns municípios do Paraná, vizinhos a São Paulo também fazem parte dessa região. Mais da metade desta população habita a zona rural e se distribui em cerca de 400 comunidades rurais (Instituto Socioambiental (ISA) , 1998; Born \& Talocchi, 2002). Uma das principais vias de acesso à região é a Rodovia Régis Bittencourt (BR -116).

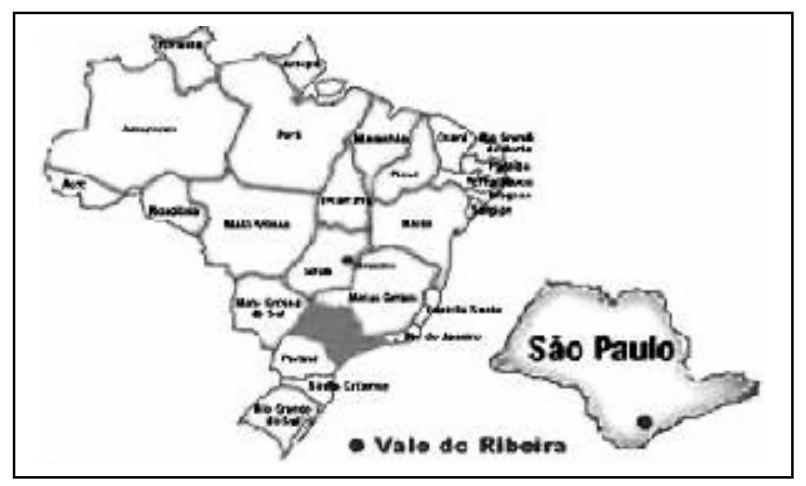

Figura 1. Localização do Vale do Ribeira no Estado de São Paulo. Fonte: Adaptado do Mapa de Vegetação do Inst. Florestal, 2002.

O clima regional é caracterizado como subtropical úmido, com temperatura média anual de $18^{\circ} \mathrm{C}$ e precipitação anual podendo atingir até $4.000 \mathrm{~mm}$. O relevo é fortemente ondulado, 
altitude variando entre 100 a 1000 metros o que caracteriza áreas de difícil acesso, e solos predominantemente podzólicos e latossolos vermelho amarelos, e também solos hidromórficos de várzeas.

O Vale do Ribeira destaca-se por concentrar a maior área contínua de Mata Atlântica do país. São mais de 2.1 milhões de hectares de florestas, equivalente a aproximadamente $21 \%$ dos remanescentes de Mata Atlântica do país, 150 mil hectares de restingas e 17 mil hectares de manguezais conservados². Além de abrigar um dos mais importantes patrimônios espeleológicos do Brasil e de ser recentemente declarada Patrimônio Natural da Humanidade pela Unesco, mais de $50 \%$ da área total da região está sob regime de proteção ambiental através das Unidades de Conservação de uso direto e indireto que foram criadas ao longo do século XX (ISA, 1998; Born \& Talocchi, 2002).

"Ao lado dos significativos recursos naturais, a região possui grande importância em termos de diversidade cultural, por seu valor histórico, por conter a maior quantidade de sítios tombados do Estado de São Paulo e inúmeros registros arqueológicos, ainda pouco estudados. Em contraposição aos ricos patrimônios ambiental e cultural, o Vale do Ribeira apresenta os mais baixos indicadores sociais dos Estados de São Paulo, incluindo os mais altos índices de mortalidade infantil e analfabetismo" (ISA, 1998).

Segundo Petrone (1966), um dos principais problemas da região do Vale do Ribeira está centrado na regularização fundiária das terras ocupadas e não ocupadas, fato que já vinha sendo apontado desde 1960 nas caracterizações realizadas sobre a região. Quase a totalidade das populações rurais que historicamente habitam a região, detêm somente a "posse da terra" (em muitos casos, posse em caráter comunal e sem documentações que comprovem seus direitos possessórios). Nesse sentido, a maior parte das áreas ocupadas e manejadas por estas populações, ou são de domínio do poder público, ou de particulares (pessoas físicas e jurídicas) que não residem na região (Adams, 2000). É dentro desse contexto fundiário que se inserem os caiçaras, índios, ribeirinhos e quilombolas ${ }^{3}$ - populações consideradas "tradicionais", pois

\footnotetext{
${ }^{2}$ Atlas da Evolução dos Remanescentes Florestais e Ecossistemas Associados do Domínio da Mata Atlântica no Período 199095, Fundação SOS Mata Atlântica, Instituto Nacional de Pesquisas Espaciais - INPE e Instituto Socioambiental - ISA, 1998.

3 Termo aplicável a toda comunidade negra rural que agrupe descendentes de escravos vivendo da cultura de subsistência e onde as manifestações culturais têm forte vínculo com o passado.
} 
mantém muitos aspectos culturais seculares e praticam, sobretudo, uma agricultura voltada à sua subsistência.

\subsubsection{0 contexto agrícola: A Bananicultura}

A agricultura, ainda hoje, é a principal atividade econômica no Vale do Ribeira, seja na forma da agricultura familiar como patronal (Resende, 2002).

A bananicultura ${ }^{4}$ se destaca na economia agrícola regional, vindo a seguir, a produção de feijão, arroz e milho e a criação de gado (Instituto de Terras do Estado de São Paulo (ITESP), 2000).

Nas primeiras décadas do século XX houve o crescimento das lavouras de chá e banana na região do Vale do Ribeira, quando então a banana passou a ser o principal produto econômico do Vale do Ribeira, representando 60\% do valor da produção agrícola regional. Em 1991, chegou a representar 96\% da produção de banana do Estado. Porém, a região gradativamente está perdendo mercado para outros Estados brasileiros, dentre eles Santa Catarina e Minas Gerais, devido ao fato dos produtores do Vale terem, na média, baixo grau de organização (Resende, 2002). Outro fator que vem sendo apontado como a causa do Vale do Ribeira perder sua posição de líder no mercado para outras regiões do país seria os diferentes sistemas de produção agrícola voltados à bananicultura ainda praticados na região. Autores como Resende (2002) e Born \& Talocchi (2002) retratam existir no Vale do Ribeira produtores agrícolas que detém melhores tecnologias e utilizam insumos modernos e produtores agrícolas totalmente descapitalizados, que contam apenas com a mão de obra familiar. Os grandes produtores ocupam áreas mais planas e sem problemas fundiários, contam com acesso à energia elétrica $\mathrm{e}$ conseqüentemente tendem a ocupar uma melhor situação frente ao mercado competitivo. Já os agricultores familiares tendem a se concentrar em áreas mais acidentadas, que possuem coberturas vegetais nativas, e em geral, não têm titularidade definitiva. Essas características somadas à falta de infra-estrutura refletem um menor poder de barganha no mercado (Resende,

\footnotetext{
${ }^{4} \mathrm{O}$ Brasil se destaca como o segundo produtor mundial de banana com 5.5 ton. (FAO, 2001). A bananicultura é considerada uma atividade importantíssima na geração de renda e fixação da mão-de-obra rural brasileira. Atualmente esta cultura agrícola é cultivada em todos os estados brasileiros, desde a faixa litorânea até os planaltos do interior, embora o seu plantio sofra restrições, em virtude de fatores climáticos, como temperatura e precipitação.
} 
2002). Este é o caso da grande maioria das comunidades rurais autóctones do Vale do Ribeira dentre essas, as comunidades quilombolas.

Até os dias atuais, a bananicultura se faz presente vivamente junto à paisagem do Vale. Para a maioria das comunidades rurais, essa cultura, mesmo com baixos índices de capitalização e tecnologia, é a atividade agrícola predominante. Todavia, esta prática agrícola não exclui 0 exercício de outras atividades que complementam a economia de subsistência das famílias, como a pesca, o artesanato, o cultivo de plantas medicinais, ornamentais e aromáticas e ainda a extração ilegal do palmito em localidades da região (Born \& Talocchi, 2002).

No caso das comunidades quilombolas do Vale do Ribeira, a bananicultura juntamente com a extração do juçara (palmito) passaram a ser as principais atividades econômicas desde meados do século XX (Sodrzeieski, 1998).

Por incentivo dos grandes bananicultores da região, as comunidades quilombolas de Sapatu e Ivaporunduva foram, nos anos de 1980, as primeiras comunidades a ingressarem na bananicultura (Carril, 1995).

Nessa mesma década, com a chegada de fazendeiros e grileiros na região, houve um êxodo bastante grande da zona rural para a cidade e, neste período, também aumentou a abertura de áreas para pastagem (Mirales, 1998). Essas mudanças causaram danos para as comunidades quilombolas do Vale, sendo que, muitos indivíduos foram para outras cidades e também para capital de São Paulo e Curitiba em busca de trabalho, abandonando suas roças; alguns até venderam suas posses para terceiros.

\subsubsection{0 contexto social: As Comunidades Quilombolas}

A região do Vale do Ribeira, em meados do século XVI, encontrava-se povoada por colonos europeus (Queiroz, 1997). Nessa época, estes mantinham a economia extrativista e agrícola do Brasil colônia através de seus escravos índios elou negros, recém trazidos das regiões africanas também conquistadas. "Por muito tempo, a economia do Brasil colônia esteve totalmente apoiada na mão-de-obra escrava, sobretudo negra. No Vale do Ribeira, esta se destacou, principalmente, durante a mineração do ouro - primeiro ciclo econômico da região. No século XVII, em função do ouro encontrado às margens do rio Ribeira de Iguape, deu-se origem 
à primeira cidade do interior do Vale, Xiririca, atualmente conhecida como Eldorado5" (ITESP, 2000, p.21).

"Muitos ex-escravos que permaneceram na região após o término do ciclo do ouro no Vale, ocuparam as terras e desenvolveram uma agricultura também voltada ao mercado. Este mercado era de produção de alimentos tanto para consumo regional, como para o comércio, em outras regiões do país. Assim foi o caso do ciclo do arroz, que teve início no final do século XVII na região do Vale do Ribeira e que foi intensamente comercializado para o mercado externo até meados do século XIX" (ITESP, 2000, p.25; Simão, 2003 e Sanches,1997).

No estado de São Paulo, até o momento, foram identificadas pelo ITESP 37 comunidades quilombolas, nas regiões Sul (Vale do Ribeira), Sudoeste e Sudeste (Litoral Norte) (ITESP, 2004).

O Vale do Ribeira é a região que concentra o maior número de comunidades remanescentes de quilombos do estado de São Paulo que, segundo Carril (1995), formaram-se com a libertação, fuga e/ou abandono dos escravos, após a decadência do ciclo econômico da mineração na região. Das 25 comunidades quilombolas que se sabe da existência na região, doze são hoje reconhecidas pelo Estado e onze delas estão localizadas nos municípios de Iporanga e Eldorado (ITESP, 2004).

As comunidades de Ivaporunduva, André Lopes e Sapatu estão localizadas no município de Eldorado, situado a $242 \mathrm{Km}$ de distância da capital do estado de São Paulo. Este possui uma população de 14.465 habitantes e uma área total de 1.712 Km² (Fundação SEADE, 2004). Sapatu e André Lopes têm parte de suas terras sobrepostas pelo Parque Estadual de Jacupiranga e a comunidade de Ivaporunduva tem o Parque Estadual de Intervales como vizinho e localizadas na beira da Rodovia SP 165 (ITESP, 1998a). As três comunidades têm suas terras banhadas pelo rio Ribeira de Iguape, conforme pode ser observado no mapa I (em anexo).

Até 0 inicio de 1970, as terras ocupadas e manejadas pelas comunidades quilombolas eram comunais, isto é, de uso coletivo. Havia apenas os limites entre uma comunidade-bairro e a outra - situação que todos aqueles pertencentes às comunidades conheciam e respeitavam. Após esse período, houve uma tentativa de regularização fundiária das posses rurais no Vale do

\footnotetext{
${ }^{5}$ Esta mudança do nome Xiririca para Eldorado foi realizada em 1948, com a aprovação da Assembléia Legislativa do Estado de São Paulo, em homenagem às riquezas auríferas existentes na região no passado (Carril, 1995, p.80).
} 
Ribeira, em que as comunidades quilombolas foram inseridas. Através de um convênio entre a Superintendência para o Desenvolvimento do Litoral Paulista - SUDELPA e a Procuradoria do Patrimônio Imobiliário - PPI (que foi mantido de 1970 a 1976), foi iniciada a demarcação de terras e a distribuição de títulos de propriedade a pequenos posseiros. Todavia, essa "demarcação" desconsiderava a existência das terras comunais, tratando de loteá-las. Com isso, algumas pessoas venderam seus lotes a pessoas de fora, gerando conflitos internos e, de fato, poucas famílias receberam seus títulos (Carril, 1995). As famílias continuaram sem posse do registro legal de propriedade privada individual da terra e mantiveram suas normas internas, como forma de se manterem frente à nova realidade territorial imposta.

As comunidades quilombolas sempre mantiveram certa relação de dependência com os pequenos núcleos urbanos regionais, com os grandes proprietários rurais e as autoridades locais. Ou seja, os quilombolas quando obtinham trabalho fora de suas comunidades era na qualidade de meeiro, de pequeno produtor e de empregado (Diegues, 2000).

Mesmo encontrando-se isoladas geograficamente, nunca viveram descontextualizadas da produção agrícola regional. Ao contrário, mantiveram intensa relação econômica - atuando como fornecedoras de gêneros alimentícios para o mercado local, regional e mesmo mundial no caso a produção de arroz de excelente qualidade (ITESP, 2000).

Segundo Born \& Talocchi (2002), em função das restrições de uso e ocupação do solo, principalmente a partir das décadas de 50-60 até o início da década de 90, período em que se estabeleceu a maioria das Unidades de Conservação (UC) ${ }^{6}$ no Vale do Ribeira, as comunidades quilombolas foram forçadas a incorporarem outras formas de acesso aos recursos ambientais locais e à subsistência.

Ainda podem ser observadas áreas de capuavas $^{7}$ usadas para produção agrícola, mas esse sistema é praticado em menores extensões de terra, ou seja, as áreas hoje cultivadas são bem menores se comparadas com o tamanho dessas no passado. Pois com a criação das leis ambientais, começaram as restrições de determinadas atividades que implicavam em supressão

\footnotetext{
${ }^{6}$ São espaços territoriais e seus recursos ambientais, incluindo as águas jurisdicionais, com características naturais relevantes, legalmente instituído pelo Poder Público, com objetivos de conservação e limites definidos, sob regime especial de administração, ao qual se aplicam garantias adequadas de proteção. As UCs se constituem um dos mais importantes mecanismos para preservação da biodiversidade "in situ". Mais detalhes ver na Lei n 9.985/ 2000 que estabeleceu o Sistema Nacional de Unidades de Conservação (SNUC).

${ }^{7}$ Este sistema de produção consiste em cultivar em locais distantes, devido à maior disponibilidade de área e por também servirem de moradia (Simão, 2001).
} 
da vegetação e extração de recursos. Surgem novos padrões de ações de sobrevivência para essas comunidades, alterando práticas centenárias como a extração de produtos na mata e 0 sistema tradicional de agricultura de corte e queima.

Os artigos 68, 215 e 216 da Constituição Federal de 1988, que estabelecem a regulamentação das terras de quilombos, afirmam positivamente a sua identidade quilombola, incentivando-os a rever sua história, memória, família e a demarcarem as terras coletivas. De um outro lado estão as leis ambientais que restringem as práticas de agricultura itinerante e 0 extrativismo (Mirales, 1998).

As comunidades quilombolas do Vale, assim como outras comunidades tradicionais, ainda hoje vêm sendo freqüentemente atingidas ou ameaçadas pela grilagem de terras e por projetos de construção de barragens hidrelétricas ${ }^{8}$ (Andrade,1997).

A organização político-social das comunidades rurais negras do Vale foi iniciada em meados dos anos oitenta, a partir do trabalho de base realizado pela Comissão da Pastoral da Terra (CPT), cujo tema central foi a organização das comunidades locais para enfrentar os projetos de barragens (Hidrelétrica de Tijuco Alto, Funil, Batatal e Itaóca). Esse movimento faz parte do cenário político-social do Estado contra a implementação das barragens na região do Vale do Ribeira (ISA, 2002).

Vale ressaltar que as comunidades estudadas estão organizadas formalmente por associações comunitárias. Essas comunidades reivindicam o direito de terem a titulação de suas terras e, principalmente, se posicionam contra a construção de barragens no rio Ribeira, proposta pela Companhia Energética de São Paulo até os dias de hoje.

As negociações entre a Secretaria do Meio Ambiente do Estado de São Paulo (SMA) e as comunidades quilombolas localizadas no entorno das Unidades de Conservação criadas no Vale, até os dias atuais giram em torno de reivindicações quanto ao direito de terem as terras que

\footnotetext{
${ }^{8}$ Estas barragens, se construídas, inundarão permanentemente uma área de aproximadamente 11 mil hectares, incluindo áreas dos Parques Estaduais Intervales, Jacupiranga e Alto Ribeira, áreas urbanas, como o centro histórico da cidade de Iporanga, além de áreas de comunidades rurais que vivem às margens do rio Ribeira, incluindo várias comunidades de quilombolos, dentre elas Sapatu, Ivaporunduva e André Lopes (ISA, 2002). Pela ameaça de construção das barragens, essas comunidades quilombolas se uniram como objetivo de acionar o governo do Estado buscando regularizar a situação fundiária de suas terras, cumprindo o disposto que reza o Art.68, da Constituição Federal de 1988: "aos remanescentes das comunidades dos quilombos que estejam ocupando suas terras é reconhecida a propriedade definitiva, devendo o Estado emitir-Ihes os títulos respectivos". É fato conhecido a influência direta e ativa da Igreja Católica através dos trabalhos desenvolvidos pelas irmãs da Congregação de Jesus Bom Pastor, com relação ao fomento da organização social de base junto às comunidades quilombolas, como é o caso do Movimento dos Ameaçados por Barragens - MOAB, que tem uma sede na cidade de Eldorado e é liderado por membros das comunidades quilombolas da região.
} 
ocupam regularizadas, ou seja, reconhecidas pelo Estado como sendo território quilombola, com exceção de Ivaporunudva, que possui o título de domínio da terra expedido em nome da associação dessa comunidade.

\subsection{Os planos de desenvolvimento para o Vale do Ribeira.}

De acordo com Resende (2002), no Vale do Ribeira, desde 1959, vêm sendo implantados diversos programas e projetos visando à promoção e ao desenvolvimento da região. O que se observa comumente nos projetos de cunho social implantados no Vale é o caráter assistencialista de todos. O autor afirma que até os dias de hoje é possível ver, em muitos desses projetos, a ausência do envolvimento da sociedade local no planejamento e na execução dos mesmos.

Segundo Todeschini (2002), entre os anos de 1950 e 1979 foram implementados vários planos para o país, como por exemplo, o II Plano Nacional de Desenvolvimento (II PND), que tinha como objetivo explícito promover o desenvolvimento regional e desconcentrado, baseado em investimentos maciços do Estado e de grandes grupos econômicos privados. Esses planos foram elaborados e implementados sem uma articulação com a realidade do lugar onde seriam inseridos, refletindo a ação do Estado centralizador, cujo objetivo era o desenvolvimento de setores da economia nacional e não dos locais onde eram implantados.

Resende (2002), referindo-se às ações e políticas públicas já implantadas no Vale do Ribeira, cita que a primeira experiência do governo do Estado de São Paulo voltada à problemática da propriedade da terra, à regularização fundiária e ao desenvolvimento de programas de crédito rural para a região, ocorreu no governo no início dos anos 1960, denominado "Plano de Ação". Esse foi o passo inicial para a criação da Superintendência do Desenvolvimento do Litoral Paulista (SUDELPA). No governo seguinte foi criado o "Plano Global para o Desenvolvimento do Vale do Ribeira e Litoral Sul de São Paulo", dando prosseguimento às iniciativas de planejamento para o desenvolvimento de tais regiões.

No ano de 1969, a SUDELPA foi criada dando início ao Plano de Desenvolvimento do Litoral (PLADEL), de atuação no Vale e em todo o litoral de São Paulo. Tinha como objetivo a implantação de grandes obras hidrelétricas no Vale, como foi o caso da criação da barragem do 
Vale Grande e o pólder ${ }^{9}$ Registro I (Resende, 2002). Segundo a análise de Resende, a respeito dos planos políticos para o desenvolvimento do Vale, o PLADEL, assim como outros planos executados nesse período, raramente eram voltados às populações da região, mas sim voltados a atender os interesses políticos locais (Resende, 2002).

Ainda nesse período foi lançado o Plano Diretor de Desenvolvimento do Vale e Litoral Sul e a criação do Centro de Desenvolvimento Agrícola do Vale (CEDAVAL). A criação do CEDAVAL se deu por interesse do Governo japonês em fomentar o desenvolvimento da agricultura altamente capitalizada e tecnicamente sofisticada no Vale do Ribeira. Mais uma vez se implantava um plano de governo que não levava em consideração as condições ambientais, sócio-econômicas e fundiárias, peculiares desta região do Estado de São Paulo (Instituto da Cidadania,1996).

No final da década de 1970, os resultados dos planos implantados no Vale eram visíveis, com destaque para o abrupto crescimento econômico que ocorreu nesse período. Porém, esse crescimento foi acompanhado por uma intensa concentração de renda e agravamento dos desequilíbrios regionais (Todeschini, 2002).

Nos anos 80, o Vale foi alvo de atenção do Governo Estadual, pelo fato que de a região encontrava-se em subdesenvolvimento econômico, em relação às demais regiões de São Paulo. Várias foram as explicações apontadas para tal fato, dentre elas a irregularidade fundiária e também por não ser uma região propícia à expansão de uma agricultura atrativa à agroindústria (Carril, 1995).

Conforme Martinez (1995), entre os anos de 1979 a 1982, a ação governamental para integração da região do Vale ao resto do Estado foi através da melhoria da infra-estrutura das estradas que dão acesso à região e, conseqüentemente, aumentou a especulação imobiliária. Essas mudanças resultaram na valorização das terras, despertando interesses de latifundiários e de empresários de outras regiões, gerando assim diversos conflitos fundiários em diversos locais do Vale.

\footnotetext{
${ }^{9}$ Extensão de terras baixas recuperadas, por uma obra de terra para conter as águas de um rio num determinado trecho ou para evitar as inundações decorrentes de ondas de cheia ou de marés. Fonte: http://www5.prossiga.br/recursoshidricos/glossario (03 de março de 2005).
} 
Resende (2002) relata que o período de 1982 a 1986 foi aquele em que mais se priorizou as questões sociais e ambientais no Estado de São Paulo. Resende cita como exemplos de ação do governo durante esses quatro anos, o Convênio São Paulo/Paraná, para gestão integrada do Complexo Lagunas de Iguape - Cananéia - Paranaguá; o Plano Básico de Desenvolvimento Sustentado para região Lagunar de Iguape e Cananéia; o MASTERPLAN (projeto que envolveu vários órgãos governamentais do Estado), cuja proposta foi diagnosticar os fatores limitantes do desenvolvimento da agricultura no Vale. Para este fim, foi criado um grupo de Resolução de Conflitos de Terras e um de Regularização Fundiária de Parques e Reservas Florestais. Esse mesmo projeto também se propôs gerar pacotes tecnológicos adequados à região e à proteção dos recursos naturais.

O Estado, a partir de 1982, se apoiou nas organizações sociais existentes na região do Vale, para desenvolver suas políticas de desenvolvimento rural e incentivou a organização rural na forma de associações (Resende, 2002). Ainda nesse período, setores da Igreja Católica fomentaram a organização das populações rurais para permanência nas terras que já ocupavam há várias décadas. No caso das comunidades quilombolas, este processo se deu mais precisamente através da motivação dos membros dessas comunidades a se organizarem formalmente como associações comunitárias e assim atenderem às exigências governamentais para entrarem no processo de reivindicação da titulação das suas terras junto ao Estado.

Em 1991 a SUDELPA foi extinta. Afirma Resende (2002) que tal instituição teve papel importante no contexto das políticas públicas que visavam à promoção do desenvolvimento do Vale.

Nos anos de 1990, inicia-se a implementação de programas de inspiração neoliberal pelo Governo Federal, como a abertura econômica abrupta e a estabilização monetária atingida através de elevados juros e alteram significativamente o quadro econômico no país. Cadeias produtivas foram desintegradas e o nível de emprego formal na economia diminuiu sensivelmente, resultando no agravamento das frágeis condições sociais do país, incluindo 0 aumento da exclusão social e da concentração de renda (Tedesco, 2001).

Segundo Born \& Talocchi (2002), em virtude da redemocratização do país, pelo trabalho das lideranças locais e de instituições do Estado, especialmente da capital de São Paulo, visando ampliar a cobertura de áreas protegidas, o Vale do Ribeira tornou-se alvo de atenção por parte 
de organizações do governo. Dentre elas a Fundação Florestal (FF), órgão vinculado à Secretaria de Meio Ambiente do Estado de São Paulo (SMA), que tem por objetivo contribuir para conservação, manejo e ampliação das florestas de proteção e produção do Estado, além de apoiar, promover e executar ações integradas também voltadas para o desenvolvimento sustentável (FUNDAÇÃO FLORESTAL, 2005). Este foi o caso do projeto de repovoamento do palmiteiro juçara cujo objetivo foi a regularização da exploração desse recurso florestal na região do Vale do Ribeira, principalmente no entorno dos Parques Estaduais. Esse projeto foi iniciado em 1999 pela FF com as comunidades quilombolas localizadas no entorno do Parque Estadual Intervales.(FUNDAÇÃO FLORESTAL, 2005). No caso do Instituto de Terras do Estado de São Paulo (ITESP) - órgão responsável pelas políticas agrária e fundiária do Governo do Estado de São Paulo e pela identificação das comunidades quilombolas - além dessas funções que the é de responsabilidade, ele também colabora na prestação de assistência técnica aos produtores rurais sem terra, assentados e quilombos (ITESP, 2005). Assim como a Fundação Florestal, o ITESP é uma instituição governamental estatal presente no cenário sócio-ambiental do Vale do Ribeira desde a década de 90.

No caso das comunidades quilombolas, o ITESP, após a identificação das mesmas e havendo interesse de seus moradores, inicia um estudo antropológico para reconhecê-las. Sendo reconhecidos, os quilombos que ocupam áreas públicas estaduais recebem do Estado o título de domínio das terras, emitido em nome da associação. Vale mencionar que a titulação é um direito garantido pela Constituição de 1988. Já os quilombolas que vivem em áreas consideradas particulares ou da União ficam na dependência do Incra, órgão federal responsável pela execução da reforma agrária e responsável por realizar desapropriações de terras improdutivas para esta finalidade.

Além da atenção por parte de órgãos governamentais, o Vale do Ribeira se tornou alvo de projetos e ações de entidades não governamentais como a Mitra Diocesana de Registro (uma organização da Igreja Católica diretamente ligada ao Vaticano); a Comissão da Pastoral da Terra10; (CPT); o Fraterno Auxílio Cristão (FAC); o Instituto Sócioambiental (ISA), que vem desde

\footnotetext{
10 Um dos principais objetivos da Pastoral da Terra é fomentar ações que levam as comunidades a se organizarem socialmente, como por exemplo, incentivo à formação de lideranças capazes de provocar mudanças e de reivindicar o direito ao reconhecimento das terras que essas comunidades ocupam. Há também pessoas voluntárias nas comunidades, as quais desenvolvem na sua própria comunidade ações voltadas à assistência nutricional das crianças, no caso a Pastoral da Criança.
} 
1997 trabalhando com a associação local de Ivaporunduva e no ano de 2000 deu início ao projeto de certificação orgânica da banana que é produzida nessa comunidade. $O$ objetivo deste projeto é gerar renda para a comunidade, de forma compatível com as condições sociais, econômicas e ambientais locais (ISA, 2004); a SOS Mata Atlântica e o Vitae Civilis, organizações que têm trabalhos no Vale voltados à conservação ambiental concomitantemente às populações locais.

Carril (1995), que abordou em seus trabalhos os projetos implantados no Vale, especialmente em comunidades quilombolas desta região, discorre que as várias alternativas que visavam ao desenvolvimento do Vale do Ribeira partiram do princípio de que faltava modernização das estruturas econômicas regionais, tais como estradas e uma produção agrícola tecnificada. Então buscou-se setores econômicos que investissem no Vale e foram atraídas empresas de reflorestamento, empresas de mineração, agroindústrias, assim como incentivos para o desenvolvimento do turismo, projetos hidrelétricos e a criação de Unidades de Conservação.

Esses setores foram vistos como a única possibilidade de intervenção frente ao atraso econômico da região. Entretanto, não levaram em consideração as comunidades ali existentes e suas variáveis culturais (Carril, 1995), variáveis estas que, ao longo de séculos, mantiveram essas comunidades na região, sem a necessidade de uma estreita relação com o grande capital.

Resende (2002) faz referência a Braga (1998) e Muller (1980), os quais fazem uma avaliação a respeito da intervenção do Governo Estadual no Vale até os anos 80 e concluem que a falta de democracia do planejamento das ações por parte do Estado, assim como a ausência da participação dos grupos sociais locais resultaram em experiências de pouco êxito com relação ao aspecto do desenvolvimento sócio-econômico para as populações da região.

$\mathrm{Na}$ década de 90, foram lançados na região do Vale projetos de apoio à agricultura familiar, tais como: o Projeto Emergencial de Apoio à Pequena Agricultura (PEAPA); o Programa de Ação Comunitária Integrada do Vale (PACl - VR) e o Projeto de Monitoramento Agrícola do CEDAVAL (Instituto da Cidadania, 1996).

O Vale do Ribeira é a maior região produtora de banana do Estado de São Paulo e a segunda maior do país. Entre os produtores rurais do Vale que estão ligados à bananicultura, há o procedimento comum para descarte dos resíduos, ou seja, dos pseudocaules (troncos), é após 
a colheita do cacho da bananeira cortar o tronco e deixa-lo nos bananais para que naturalmente sejam incorporados ao solo, como adubação. Essa técnica gera alguns problemas fitossanitários como,por exemplo, a broca da bananeira e a proliferação de fungos que causam doenças nos bananais.

Visando uma possível utilização destes resíduos e a solução desses problemas, em 1991, o Consórcio de Desenvolvimento Intermunicipal do Vale do Ribeira11 (CODIVAR) solicitou à Secretaria de Ciência, Tecnologia e Desenvolvimento Econômico do Estado de São Paulo, um estudo que resultasse em uma alternativa econômica de utilização desses resíduos. Para tanto, a Secretaria financiou um projeto de pesquisa executado pela Escola Superior de Agricultura "Luiz de Queiroz" (ESALQ), da Universidade São Paulo (USP), denominado "Projeto de Aproveitamento de Resíduos da Agroindústria da Banana no Vale do Ribeira, SP". Esse tinha como objetivo realizar estudos que resultassem em propostas alternativas e economicamente viáveis para o aproveitamento de tais resíduos e que viessem a contribuir para a geração de empregos na região. Assim sob a coordenação geral das profa. Dra. Silvia Maria Guerra Molina e Adriana Nolasco foi elaborado e desenvolvido o referido projeto. Nesse foram pesquisadas formas de utilização dos resíduos da bananicultura na alimentação animal e humana, como substrato para o cultivo de cogumelo comestível, para fins têxteis e na produção artesanal. Dentre estas alternativas a que se mostrou de menor custo e de maior viabilidade para implementação foi a do artesanato desenvolvido a partir da fibra e palha obtidas do pseudocaule, resíduo disponível nos bananais, após o corte e extração do cacho de banana.

A área de Antropologia, Extração e Processamento Artesanal - responsável pela pesquisa de uso da fibra de bananeira na produção artesanal - do Projeto coordena pela profa Dr. ${ }^{a}$ Maria Elisa de Paula Eduardo Garavello. Esta área, na $1^{\mathrm{a}}$ fase (em 1994), recebeu da Secretaria de Ciência, Tecnologia e Desenvolvimento Econômico do Estado de São Paulo o montante financeiro de aproximadamente US $\$ 100.000,00$ e na $2^{2}$ fase (1994) após a renovação US $\$ 120.000,00$, com duração de 3 anos cada fase (Garavello, 2001).

O uso da fibra de bananeira na produção artesanal se deu inicialmente através de testes experimentais com as folhas e com o tronco de bananeira - o pseudocaule, até chegar à seleção

11 CODIVAR foi criado na década de 90, com a finalidade de promover a articulação entre todas as prefeituras do Vale, e consequentemente, captar recursos do Governo Federal visando o desenvolvimento econômico da região. 
deste como matéria prima para obtenção de fibras. Foram também estudadas técnicas para coletar desse material nos bananais, o processo de extração e de tratamento, até a obtenção da fibra de bananeira viável de ser utilizada na tecelagem e em outras produções artesanais. Também foram pesquisadas técnicas de polpação do pseudocaule (técnica de obtenção da celulose) para confecção de papel artesanal.

Esse projeto teve um segundo momento de trajetória, a partir de 1997, justamente quando foi dado início aos cursos de capacitação no Vale, ou seja, o repasse da técnica para utilização dos resíduos da bananicultura na produção artesanal, desenvolvida durante os anos de pesquisa mencionados.

Foram ministrados em 97 esses primeiros cursos de capacitação em algumas comunidades e/ou municípios do Vale do Ribeira, como Iguape, Miracatu, Juquiá, Itariri e em algumas comunidades quilombolas do município de Eldorado, André Lopes e Ivaporunduva.

Nos anos de 1998 e de 2000 os cursos foram difundidos para as comunidades quilombolas vizinhas, Sapatu e Nhunguara. Até 0 ano de 2000, foram realizados 29 cursos de capacitação do artesanato com fibra de bananeira na região do Vale do Ribeira (Garavello, 2002).

Após a finalização do "Projeto de Aproveitamento de Resíduos da Agroindústria da Banana no Vale do Ribeira", em 1997, a equipe de trabalho da área artesanal do projeto buscou parceiros pontuais junto a instituições governamentais, não governamentais e do terceiro setor, para viabilizar a continuidade da execução do trabalho de extensão e pesquisa voltada ao uso de resíduos da bananeira na produção artesanal junto a algumas comunidades do Vale, entre elas as quilombolas de Ivaporunduva, André Lopes e Sapatu (Garavello, 2001).

Atualmente a ESALQ está envolvida com a atividade artesanal com fibra de bananeira nas comunidades quilombolas de Ivaporunduva, André Lopes, Sapatu e Nhunguara. Tal envolvimento tem se dado através de ações de pesquisa e de extensão rural executadas por docentes, pesquisadores, universitários e técnicos, com o financiamento de alguns projetos em 2004 pelo CNPq, Fapesp e a Pró Reitoria de Extensão da USP. Deste modo estão sendo realizadas ações pontuais junto às comunidades quilombolas mencionadas, para fortalecer a atividade artesanal com fibra de bananeira praticada.Uma vez que, esta hoje, é considerada por 
algumas pessoas dessas comunidades uma alternativa econômica viável e compatível com a realidade sócio-ambiental em que essas se encontram.

Santos (2002) defende que é necessário ocorrer uma transformação efetiva da sociedade para um modelo de desenvolvimento viável em níveis regionais e locais, de forma que sejam defendidas estratégias de modus operandis alternativos, contra hegemônicos.

\subsection{0 conceito de desenvolvimento.}

A primeira definição de desenvolvimento surgiu no século XVIII, por concepção de C.F. Wolff, que o definiu como a realização de potencialidades sócio-culturais e econômicas de uma sociedade em perfeita sintonia com o seu entorno ambiental (Sevilla Guzmán et al., 1999 e Esteva, 1996). A partir da construção do pensamento liberal, o significado de desenvolvimento passou a ter uma outra conotação, a de crescimento econômico centrado nos padrões de vida e consumo das nações já industrializadas. Por essa ótica se construiu um modelo de sociedade ocidental, capitalista e industrializada, ou seja, um modelo de organização social considerado desenvolvido por adoção de tecnologias estratégicas geradoras de crescimento econômico (Esteva, 1996 e Boff, 1996).

Ocorre entretanto, que o padrão de consumo gerado por essa ótica de desenvolvimento é um dos fatores preponderantes da degradação ambiental e da exauribilidade do estoque de capital natural, que compreende todos os conhecidos recursos usados pela humanidade, desde a água, os solos, os minerais, os vegetais e animais, abrangendo também os seres vivos, incluindo todos os ecossistemas (Albuquerque \& Araújo, 1995 e Hawken et al., 1999). Nesse sentido, contrapõe-se à idéia original de Wolff.

Segundo Albuquerque \& Araújo (1995), mesmo lentamente, tem havido uma tendência dos setores econômicos em considerarem que o meio ambiente é o elemento condicionante da atividade econômica e a escassez de recursos naturais pode provocar um colapso no sistema econômico.

Boff (1996) afirma que o desenvolvimento econômico global atual não produz simultaneamente o desenvolvimento social universal. E assim vem contribuindo para agravar os problemas sócio-ambientais. 
A visão dos países do norte a respeito da problemática ambiental global não é suficiente para compreender e resolver os problemas dos países do sul. Isto, porque a diversidade cultural dos países ditos subdesenvolvidos abre perspectivas mais complexas de análises das relações e processos ecológicos, tecnológicos e culturais que determinam uma forma integrada e sustentável a respeito do uso de seus recursos (Leff, 2002).

Na prática, a sociedade deve mostrar-se capaz de assumir novos hábitos e de projetar um tipo de desenvolvimento que cultive o cuidado com o equilíbrio ecológico (Boff, 2002). A crise ambiental é o reflexo do modo como a questão ecológica foi suplantada pelos padrões dominantes de consumo em função do crescimento econômico (Leff, 2001).

Com a comprovação de que o modelo de crescimento, com base no imperativo econômico não alcançou os objetivos que pretendia, nascem as correntes de sustentabilidade como uma resposta a estes resultados negativos (Escobar, 1995).

Boff (1996) aponta que é necessário se chegar a uma economia do suficiente, isto é, a uma economia que não seja aquela orientada pela acumulação de capital e centrada no crescimento ilimitado. A prática do aproveitamento dos resíduos da bananicultura para produção artesanal, dialoga com a questão levantada por Boff, uma vez que a atividade artesanal com fibra de bananeira não é uma atividade que propõe ser exercida visando o acúmulo de capital, mas sim, ser exercida de forma complementar a outras atividades já executadas dentro das comunidades é baseada na economia do suficiente.

O autor defende ainda, que as políticas de desenvolvimento devem ser adequadas à realidade do ecossistema local e regional, mas o que ainda se observa é um quadro de política pública baseada na ideologia da maximização de benefícios, mesmo que o preço seja 0 da agressão ambiental (Boff, 1996).

Ainda nesse contexto de mudança de paradigma de desenvolvimento, segundo Morin (2000, p.14) "a ferramenta do conhecimento não pode ser usada sem que sua natureza seja examinada" e que "é problemática a questão da necessidade de promover o conhecimento capaz de apreender problemas globais e fundamentais para neles inserir os conhecimentos parciais e locais". Considera o autor que há necessidade dos seres humanos tomarem ao mesmo tempo conhecimento e consciência de sua identidade complexa e comum com relação a todos e a tudo. 
Em vários países do primeiro mundo, a incorporação do tema ambiental nas políticas de desenvolvimento surge a partir de 1960, entre outros motivos como resposta a problemas decorrentes das externalidades negativas dos processos de produção industrial, especialmente no que tange a seus impactos sobre a qualidade de vida das populações (Moraes, 1998).

$\mathrm{Na}$ década de 70 , os resultados do sistema de desenvolvimento adotado pelos países industrializados, começaram a se mostrar insuficientes para dar conta das crescentes condições de desigualdade e de exclusão social. Surgem então novas orientações teóricas, tais como 0 desenvolvimento sustentável e o ecodesenvolvimento (Caporal \& Costabeber, 2004). E a questão ambiental, em 1970, passa a fazer parte da pauta de discussão a respeito do desenvolvimento econômico global, de países do norte e do sul, bem como passou a ser encarada como relevante, dentro do panorama dos problemas de conseqüências mundiais a serem solucionados (Ribeiro, 2001).

Já na década de 80, o conceito de desenvolvimento tornou-se multidimensional englobando as melhorias difundidas no campo social, como o bem estar de toda a sociedade. Adicionou-se então a este conceito a idéia de que não existe um simples modelo para atingir o desenvolvimento. E acima de tudo, que o desenvolvimento precisava ser sustentável, não devendo somente tratar das atividades sociais ou econômicas, mas também ser relacionado à população, ao uso dos recursos naturais e aos resultados dos impactos no meio ambiente (Elliot, 1999). É necessário ressaltar que a corrente liberal, também denominada ecotecnocrática "nasce no coração da modernidade ocidental" (Escobar, 1995), a qual se tornou mais conhecida através do Relatório Brundtland, divulgado a partir de 1987 sob o nome de Nosso Futuro Comum. 0 Relatório sustenta a idéia de um novo critério de racionalidade amparada por duas dimensões de solidariedade: 0 respeito para com as gerações futuras, sem esquecer a solidariedade entre as gerações do presente (CNUMAD, 1992).

Nos anos seguintes entre Relatório Brundtland, o debate ambientalista, especialmente entre agências internacionais e entre ong's, passou a enfatizar o tema do envolvimento da mulher com o Desenvolvimento Sustentado (Charkiewicz-Pluta et al., 1991).

Moreira (2000) faz alusão a Brüseke (1996), que ressalta que a origem da noção de sustentabilidade é ainda anterior ao texto Limites do Crescimento, elaborado pelo Clube de 
Roma, em 1972 e à publicação da Conferência de Estocolmo sobre Human Environment, também nesse mesmo ano.

A Conferência Rio-92 contribuiu para fomentar globalmente a reflexão sobre meio ambiente e desenvolvimento, lançada pelas reuniões preparatórias à Conferência de Estocolmo.

Atualmente, o discurso sobre o desenvolvimento econômico incorporou definitivamente a problemática sócio-ambiental, promovendo a busca de respostas referentes a problemas dessa ordem (Escobar, 1995).

\subsubsection{Ecodesenvolvimento}

O que diferencia o conceito de desenvolvimento sustentáve 12 do de ecodesenvolvimento é a relevância dada por este segundo à integração da Ecologia com outros campos da ciência, como a Geografia, a Biologia e a Sociologia, ressaltando a importância da articulação interdisciplinar das dimensões humana, sócio-política e cultural (Moreira, 2000 e Vieira, 2001). Apesar desta distinção, Sachs, segundo Chaves (2003), não vislumbra diferença entre desenvolvimento sustentável e ecodesenvolvimento.

O conceito de ecodesenvolvimento teve sua concepção baseada, a princípio, na problemática de desenvolvimento adaptado às áreas rurais do Terceiro Mundo e a uma utilização criteriosa dos seus recursos, tendo como meta o não comprometimento da natureza (Layrargues, 1997).

Sabe-se que o modelo globalizado de desenvolvimento em vigor tem provocado sérios impactos tanto nos aspectos sociais, culturais e econômicos como também ambientais, impactos estes que podem ser até irreversíveis, comprometendo a qualidade de vida local e das gerações seguintes.

A idéia de um mundo rural sustentável - e adequado à crítica das sociedades e das tecnologias industriais - aparece associada a uma mudança do acesso aos recursos produtivos, e da distribuição da propriedade rural, sugerindo que políticas significativas de reforma agrária

\footnotetext{
12 O termo desenvolvimento sustentável traz em si divergências conceituais a partir do termo "desenvolvimento". Pois para algumas pessoas este está vinculado à melhoria da qualidade de vida em sua concepção abrangente. E para outros a qualidade de vida está exclusivamente condicionada ao progresso e vinculado à necessidade de crescimento econômico (Chaves,2003).
} 
seriam necessárias para se alcançar o desenvolvimento sustentável autônomo dos países periféricos. Significando tanto uma não dependência desses em relação aos países industrializados, quanto a valorização de processos políticos participativos em nível local (Moreira, 2000).

Nesse sentido, a construção de um paradigma ambiental requer um complexo processo de reelaborações teóricas e o desenvolvimento de conhecimentos científicos e tecnológicos que dêem suporte a uma racionalidade social alternativa (Leff, 2002).

Também Moretto (2001), aponta como necessidade para a melhoria da qualidade da vida humana, a construção de um novo modo de desenvolvimento que esteja ligado a um pensamento sistêmico, multidimensional, dinâmico, que possa abranger um novo espaço econômico, social e cultural.

Em busca dessa integração, há estudiosos contemporâneos que defendem a sustentabilidade ambiental dentro de uma dimensão mais complexa (Leff, 2001; Viola \& Leis, 2001), como paradigma de um novo modo de desenvolvimento. Tais autores reagem ao reducionismo econômico e tecnológico que caracteriza o discurso oficial e consideram que não há sustentabilidade possível sem se considerar as desigualdades sociais e políticas, bem como os valores éticos de respeito à vida $\mathrm{e}$ às diferenças culturais.

Ainda nesse pensamento, Boff (1996) afirma que não se pode renunciar ao sistema vigente de desenvolvimento, mas deve-se procurar encontrar nas políticas de desenvolvimento um equilíbrio entre as vantagens desse paradigma e os custos ecológicos. Desse modo, antes de projetar e implementar um desenvolvimento ecologicamente sustentado é necessário que este seja adequado ao local. Pode-se dizer que o ecodesenvolvimento propõe soluções específicas para problemas particulares, levando em conta os dados ecológicos de cada local, as diversidades culturais e as potencialidades natas dos seres humanos e do meio ambiente onde se quer intervir.

Em contraposição ao modelo de sociedade atualmente dominante, o qual produziu a ruptura nas relações sociais e nas relações dos seres humanos com o meio ambiente, o novo modelo de desenvolvimento deve refazer o tecido social a partir das múltiplas potencialidades do ser humano e da própria sociedade. A implantação desse estilo de desenvolvimento, que respeita as gerações futuras e os recursos naturais, é uma necessidade global. Como alternativa, Sachs 
(1982), aponta para a estratégia do ecodesenvolvimento. Pois este visa a harmonização entre objetivos econômicos, sociais e ecológicos (Almeida et al, 1999).

Becker (1994) entende por ecodesenvolvimento a ecologização do "sistema social", isto é, a busca do desenvolvimento interativo entre homem e natureza, através de processos produtivos adaptados aos ecossistemas locais.

Para a implantação de uma proposta de ecodesenvolvimento, Vieira (2001, p.47.) recomenda que "o espaço recortado para fins de planejamento deve ser, em princípio, suficientemente amplo e homogêneo do ponto de vista ecológico, de forma a assegurar uma gestão a mais integrada possível da potencialidade de recursos existentes. Por sua vez, a presença de uma certa identidade sociocultural pode permitir a visualização de padrões regulares nas interações entre comunidades e seu meio ambiente, ou seja, de formas específicas pelas quais essas interações marcaram a paisagem e as atividades tradicionais na eco-região considerada".

Vale ressaltar que o termo ecodesenvolvimento foi adotado pela primeira vez em 1973 por Maurice Strong, Secretário Geral da Conferência de Estocolmo sobre Meio Ambiente (Almeida et al, 1999; Soares, 1999 e Vieira, 2001). A concepção dessa conferência foi essencialmente antitecnocrática e recomendou uma gestão mais racional dos ecossistemas, a qual deveria incluir a valorização do conhecimento empírico e da criatividade existente no interior das comunidades. Dessa maneira, nessa conferência foi defendido que o crescimento econômico e a preservação, bem como o uso sustentado dos recursos naturais, representavam dimensões necessariamente passíveis de integração (Vieira, 2001).

O conceito de ecodesenvolvimento, tratado por Strong, preconizava uma gestão mais racional dos ecossistemas locais inicialmente às regiões rurais da África, Ásia e América Latina, ganhando dimensões de crítica às relações globais entre países subdesenvolvidos e superdesenvolvidos, bem como de crítica à modernização industrial como método de desenvolvimento das regiões periféricas. Tal conceito vinha propor para estas regiões um desenvolvimento autônomo, independente daquele dos países desenvolvidos e preocupados com os aspectos sócio-político e ambiental do desenvolvimento (Moreira, 2000).

Em 1974, a versão inicial de ecodesenvolvimento foi reelaborada por Ignacy Sachs, que num primeiro momento o traduziu como sendo um "estilo", palavra esta adotada por Sachs 
(1980), de desenvolvimento aplicável às áreas urbanas e rurais, orientado para a satisfação das necessidades básicas e para a promoção da autonomia das populações envolvidas no processo. E num segundo momento, Ignay Sachs aponta o ecodesenvolvimento como um conceito teórico estratégico de desenvolvimento, que visa harmonizar 0 atendimento prioritário das necessidades básicas de uma comunidade com os limites ecológicos locais e remotos, de maneira a atender as demandas comunitárias quanto a alimentação, moradia, saúde, educação e outros recursos imprescindíveis ao seu desenvolvimento social e econômico, respeitando-se os critérios de sustentabilidade (Brüseke, 1996 e Vieira, 2001).

A fundamentação e a disseminação do ecodesenvolvimento como um conceito, em vários países, dentre eles no Brasil, é fruto do trabalho do autor Ignacy Sachs desde a década de 70 (Vieira, 2001), o qual ganhou uma interpretação mais ampla na Declaração de Cocoyoc $^{13}$, em 1974 (Almeida et al.,1999).

Vale ressaltar que este conceito foi o marco da associação entre mulher e meio ambiente. Tal abordagem trouxe à tona dois colaboradores decisivos para que a mulher também fosse percebida como portadora de mais afinidade com a natureza do que o homem. 0 primeiro deles seria a visibilidade da mulher nas zonas rurais do Terceiro Mundo face à migração do homem para os grandes centros urbanos em busca de emprego. A mulher rural passou a ser vista como um ser indispensável à realização de planos e projetos ambientalistas, já que tinha se tornado uma figura muita expressiva no contexto rural. O segundo fator decisivo foi de caráter cultural: a representação social da terra e a relação da mulher com ela, ambas capazes de gerar vida nova e de mantê-las (Fiúza, 1997). A percepção da mulher como agente ambientalista tornou-se internacionalmente mais visível após a conferência sobre o Meio Ambiente Humano.

Foi também nesta conferência que, pela primeira vez, colocou-se como necessária a discussão sobre o problema da degradação ambiental nos países considerados como desenvolvidos, ou seja, tratar a questão da sustentabilidade ambiental global de forma integrada com as questões de desenvolvimento dos países.

\footnotetext{
${ }^{13}$ Em 1974, em Cocoyoc no México, aconteceu a Conferência das Nações Unidas sobre Comércio e Desenvolvimento, que produziu um documento, a Declaração de Cocoyoc, considerado por diversos autores como fundamental para a construção da nova percepção da relação entre sociedade e natureza, incorporando à discussão a idéia de que existem limites ambientais e sociais para o desenvolvimento que devem ser respeitados (Ojma, 2003).
} 
Para Sachs, o ecodesenvolvimento busca estabelecer uma relação de harmonia entre 0 homem e a natureza, baseada nas necessidades do conjunto de uma população, e na conscientização dessas com respeito à dimensão ecológica (Vieira, 2001). É também um instrumento heurístico que permite aos planejadores e aos decisores políticos abordarem, por uma perspectiva mais ampla, o sistema de desenvolvimento vigente, para se sanar os problemas ecológicos e sócio-culturais causados por ele (Moreira, 2000).

O conceito de ecodesenvolvimento incorporou 0 argumento ecológico em sua concepção de desenvolvimento, pois considera que a natureza entra na composição do capital e não apenas nos meios de produção e de trabalho (Boff, 1996). Nesse sentido, o ecodesenvolvimento pode ser definido como uma estratégia para se promover a autonomia das populações, estimular a reflexão e a experimentação participativa de formas de crescimento econômico que priorizem 0 potencial dos recursos naturais e sociais de cada locus, mesmo que este se faça de modo mais lento (Sachs, 1980).

Segundo Almeida et al (1999), para se alcançar o objetivo do ecodesenvolvimento é necessário fundamentar o planejamento nas seguintes dimensões: social, econômica, ecológica, espacial e cultural. Destarte, é preciso introduzir processos que levem à elaboração de alternativas ao modelo de desenvolvimento vigente, sendo a organização das comunidades, dos grupos sociais e a reflexão a respeito das ações, algumas das alternativas possíveis de serem realizadas em curto prazo (Boff, 1996).

Sachs (1986) aponta o ecodesenvolvimento como estratégia para superar as barreiras impostas pela economia de mercado dominante. E defende que para o seu sucesso torna-se fundamental o desenvolvimento de tecnologias apropriadas a absorverem 0 melhor da especificidade e da variabilidade tanto humana como naturais de cada ecossistema (local ou regional) de forma particular (Sachs, 1993).

Esta seria, portanto, a proposta do aproveitamento do resíduo da bananicultura para a produção artesanal, cuja técnica foi cunhada em laboratório de uma instituição de ensino e pesquisa e disseminada para a sociedade através dos cursos de capacitação ministrados in loco, isto é, nas regiões onde esta matéria prima está disponível e faz parte do universo agrícola da população local. 
Ao defender a idéia de uma nova racionalidade com solidariedade, a qual pressupõe 0 pluralismo tecnológico e o respeito às condições do ecossistema local, às necessidades e decisões dos colaboradores sociais envolvidos (Leff, 2001; Sachs, 2000, 1994, 1988, 1986 e Vieira, 2001), o conceito de ecodesenvolvimento passou a ser adotado não só no Projeto considerado, como em vários programas e ações propostos por instituições públicas e privadas que buscavam conjugar o crescimento econômico, a geração de empregos e a proteção adequada do meio ambiente.

No Brasil, o Programa Nacional de Apoio à Agricultura Familiar - PRONAF, pode ser considerado como exemplo de estratégia com vista ao ecodesenvolvimento. É considerado um passo em direção ao desenvolvimento das zonas rurais, através da valorização econômica da agricultura familiar (Cavalcanti, 1998). Outros exemplos promissores em direção à prática do ecodesenvolvimento são os movimentos e organizações alternativas como a "Aliança dos Povos da Floresta", as cooperativas agroextrativistas, os movimentos dos Trabalhadores Atingidos por Barragens e outros segmentos marginais da sociedade brasileira (Cavalcanti, 1998).

Encontramos na literatura um esforço de muitos autores em estabelecer um conceito de desenvolvimento sustentável e outros tantos se esforçam para mostrar as insuficiências dos conceitos existentes. De acordo Caporal \& Costabeber (2004) pela ótica da ciência convencional, para agir no sentido da sustentabilidade, é necessário que este conceito seja claro e operacionalizável. Entretanto, muitos grupos sociais que alcançaram importantes ganhos no caminho da sustentabilidade, desconheciam a lógica ocidental do referido conceito. Ainda Caporal \& Costabeber (2004) relatam o avanço do conhecimento científico na construção de um novo paradigma; e afirmam que não é por falta de um consenso a respeito do conceito de sustentabilidade que devamos ficar imobilizados frente aos problemas ambientais globais.

É sob a perspectiva do ecodesenvolvimento propomos a descrever e analisar a atividade do artesanato com fibra de bananeira nas comunidades quilombolas já mencionadas. Acredita-se que o ecodesenvolveimtno não é só um referencial teórico intelectual, mas, também uma estratégia norteadora para impulsionar ações locais, rumo à construção da sustentabilidade socioambiental, econômica e cultural. Portanto, este marco teórico tem por objetivo prático fomentar padrões sócio-culturais e ambientais já existentes nas comunidades, ou seja, valorizar a dinâmica social de cada locus. 


\section{METODOLOGIA}

\subsection{Os caminhos da pesquisa: as técnicas adotadas para a coleta e análise dos dados}

Esta é uma pesquisa de natureza qualitativa. Tem a preocupação com o contexto e 0 ponto de vista dos participantes, suas idéias e sua forma de perceber a realidade sobre 0 fenômeno pesquisado (Godoy, 1995; Minayo, 1994; Taylor \& Bogdon,1987).

Para o levantamento dos dados foram utilizadas técnicas comumente trabalhadas nas Ciências Sociais como: observação participante, entrevistas informais não-estruturadas e semiestruturadas.

O primeiro passo para selecionar os entrevistados, ou seja, os colaboradores, foi localizar pessoas das comunidades quilombolas de Ivaporunduva, André Lopes e Sapatu que tinham participado dos cursos de capacitação do artesanato com fibra de bananeira. Para tanto, foi utilizada a lista com os nomes das pessoas dessas comunidades que participaram dos cursos de capacitação ministrados pela ESALQ. O segundo passo foi a realização de uma visita informal da autora desta pesquisa à casa de algumas pessoas, para estabelecer o primeiro contato na comunidade.

A partir das pessoas contatadas durante essa primeira visita, foram mapeados os artesãos que trabalham com fibra de bananeira nas referidas comunidades e as instituições que estavam envolvidas ou que já haviam tido algum tipo de envolvimento com tal atividade artesanal nas comunidades.

Nesta pesquisa os colaboradores se configuram e são classificados como: primários, secundários e externos.

Foram caracterizados como colaboradores primários: indivíduos das comunidades quilombolas de Ivaporunduva, André Lopes e Sapatu que participaram dos cursos de capacitação 
para o uso do resíduo da bananicultura como matéria-prima para a produção artesanal, lideranças locais, pessoas dessas comunidades que têm alguma ligação com esta atividade artesanal. Como colaboradores secundários foram caracterizados os indivíduos não pertencentes ou não residentes nas comunidades quilombolas foco da pesquisa: artesãos de outras comunidades quilombolas. Como colaboradores internos foram considerados os indivíduos da equipe da ESALQ envolvidos no processo. Como colaboradores externos foram caracterizados: técnicos, pessoas de instituições governamentais e não governamentais, que de algum modo, tiveram ou até o momento têm envolvimento com a atividade artesanal de fibra de bananeira.

A partir desses procedimentos metodológicos foi possível a reconstituição do processo de introdução dessa atividade nas referidas comunidades, as estratégias utilizadas e implicações ocorridas. Tal conhecimento derivou de uma análise com base nos preceitos do ecodesenvolvimento, abordando os aspectos: ambiental, social, econômico e cultural do artesanato com fibra de bananeira junto aos colaboradores envolvidos.

Ao todo foram entrevistados 32 colaboradores. Desse total, 15 eram artesãos das três comunidades pesquisadas, constituindo o grupo de colaboradores primários: 10 pessoas da comunidade de Ivaporunduva, 1 de André Lopes, 4 de Sapatu. O grupo de colaboradores secundários foi constituído por 7 artesãos de outras comunidades (Nhunguara e Morro Seco) que foram capacitados pelos "artesãos-multiplicadores"14. E 1 colaborador interno, 0 tecelão. ${ }^{15}$ da equipe da ESALQ, que ministrou os cursos de capacitação de artesanato com a fibra de bananeira nas comunidades pesquisadas.

A idade dos colaboradores primários e secundários era entre 18 a 60 anos, com escolaridade entre $3^{a}$ série do ensino fundamental e o ensino médio; em geral os mais jovens tinham completado o segundo grau completo.

Foram entrevistados 9 colaboradores externos, desses 6 foram profissionais de instituições governamentais: dois profissionais do ITESP do escritório de Eldorado; três profissionais da Fundação Florestal; uma religiosa (freira) da Paróquia de Eldorado; um profissional do ISA; 0 engenheiro agrônomo que no ano de 2000 trabalhou no ITESP com a

\footnotetext{
14 Denominação adotada para se referir aos artesãos das comunidades estudas que repassaram as técnicas desse artesanato para outras comunidades.

$15 \mathrm{O}$ artesão, o senhor Alziro Corazza, contratado pelo "Projeto de Aproveitamento de Resíduos da Agroindústria da Banana no Vale do Ribeira -SP", como profissional autônomo.
} 
organização da atividade artesanal nos quilombos de Eldorado e uma profissional do SEBRAE da Regional da cidade Registro.

As entrevistas com os colaboradores primários e secundários foram realizadas durante visitas desta pesquisadora a suas casas. A primeira visita às comunidades pesquisadas, em maio de 2003 , foi realizada juntamente com a coordenadora da equipe de trabalho que desenvolveu a pesquisa e as capacitações quanto ao uso da fibra de bananeira na produção artesanal16 e 0 artesão Alziro, com o objetivo de estabelecer o contato pessoal inicial com os artesãos e explicar a eles 0 objetivo da pesquisa. As coletas de dados nas comunidades de Ivaporunduva, André Lopes e Sapatu foram realizadas nos períodos de: maio, julho, agosto, setembro de 2003 e janeiro, fevereiro, março17, julho e agosto de 2004.

As entrevistas com os colaboradores externos foram realizadas no ambiente de trabalho dos envolvidos. Em alguns momentos, as entrevistas foram realizadas com 0 auxílio do roteiro. Além disso, materiais em forma de artigos de jornais e revistas e documentações internas do "Projeto de Aproveitamento de Resíduos da Agroindústria da Banana no Vale do Ribeira -SP" serviram de dados secundários, ajudando a compor as descrições e análises subseqüentes.

Para as entrevistas semi-estruturadas foi elaborado um roteiro de questões abordando aspectos relativos ao início da atividade do artesanato com fibra de bananeira nas comunidades foco, seus desdobramentos e a situação atual da atividade.

$O$ roteiro de perguntas foi formulado de forma que os dados obtidos permitissem a reconstrução dos fatos e dos desdobramentos das ações e a reflexão sobre as mudanças positivas ou negativas ocorridas na vida dos colaboradores.

Para o tratamento desses dados foi adotado o método da categorização (Minayo, 1994), sendo definidas três categorias: (a) ambiental; (b) social e (c) econômica.

\footnotetext{
${ }^{16}$ A profa Maria Elisa de Paula Eduardo Garavello.

17 Em 30 e 31 de março de 2004 foi realizado na ESALQ, sob a coordenação da Professora Maria Elisa de Paula Eduardo Garavello, um curso de qualidade da fibra de bananeira para os artesãos que vem trabalhando com 0 artesanato de bananeira, como é o caso do Grupo Banarte em Miracatu, da Oficina Monhangaba em Itariri, um grupo de mulheres de Pedro de Toledo, além dos artesãos das comunidades quilombolas do Vale do Ribeira. Nesta ocasião, também foram realizadas entrevistas com as artesãs das comunidades quilombolas que participaram deste curso. Foram abordadas questões relativas à produção do artesanato, à comercialização e às técnicas apreendidas nos cursos e suas adaptações. Participaram deste curso 8 artesãs das comunidades quilombolas, sendo uma artesã da comunidade de Nhunguara, uma artesã da comunidade de André Lopes, duas artesãs da comunidade de Ivaporunduva e quatro artesãs da comunidade de Sapatu.
} 


\subsection{Descrição das três comunidades envolvidas na pesquisa}

A comunidade de Ivaporunduva está situada à cerca de $55 \mathrm{Km}$ do centro urbano da cidade de Eldorado (SP). Recentemente, a comunidade conquistou o título de reconhecimento de domínio de seu território, conforme despacho da Presidência da Fundação Cultural Palmares, em cumprimento ao Art. 68 da Constituição Federal de 1988. Deste modo, Ivaporunduva tornou-se a primeira comunidade quilombola do Estado de São Paulo a conseguir a propriedade definitiva de suas terras, após uma luta de doze anos iniciada com a promulgação da Constituição Federal de 1988 (ITESP, 1998b). Esta comunidade foi a primeira no Estado a ser reconhecida como comunidade quilombola, sendo considerada a mais antiga do Vale do Ribeira e a que deu origem à formação de outras, como São Pedro, Pilões, Maria Rosa e Nhunguara (ITESP, 1998c).

Segundo levantamento planimétrico realizado pelo Instituto de Terras do Estado de São Paulo (ITESP), regional sul do Vale do Ribeira no ano de 1998, a comunidade de Ivaporunduva abrange uma área total de 2.754,3619 ha, fazendo limite com as áreas pertencentes a outras duas comunidades quilombolas: São Pedro e Pedro Cubas. De acordo com o último censo (junho de 2002), também realizado pelo ITESP, a comunidade é composta por 70 famílias, onde vivem em torno de 260 pessoas, organizadas através da Associação Quilombo de Ivaporunduva, criada em 1994 (ISA, 1998).

A principal fonte de renda das famílias residentes em Ivaporunduva advém da bananicultura, com exceção de nove aposentados e de duas pessoas que declararam possuir renda mensal fixa na comunidade: os canoeiros, prestadores de serviço da Prefeitura de Eldorado e responsáveis pela travessia de barco no Rio Ribeira de Iguape, no único ponto de acesso à comunidade.

Assim como Ivaporunduva, a comunidade de André Lopes tem sua economia baseada na produção de banana e roça de subsistência. Segundo informações junto ao ITESP e membros da comunidade, atualmente existem 3 pessoas que recebem a aposentadoria da Previdência Social como agricultores, e um contratado pela Prefeitura de Eldorado. Há uma escola e um posto de saúde, que conta com uma agente de saúde. Na comunidade há energia elétrica e água encanada. Está localizada a $40 \mathrm{Km}$ da cidade de Eldorado, faz limite com as comunidades quilombolas de Ivaporunduva e Nhunguara. A formação de André Lopes se deu através das 
estreitas relações sociais e de parentesco mantidas entre os dois núcleos, ou seja, a comunidade de Ivaporunduva com a de André Lopes (Stucchi,1998).

De acordo com o censo de junho de 2002, realizado pelo ITESP, na comunidade de André Lopes existem 76 famílias (ITESP, 2004). Sua área total é de 3.200,166 hectares, uma parte está sobreposta pela área ocupada pelo Parque Estadual de Jacupiranga, criado em 1969, conforme pode ser visto no mapa I (em anexo).

Em 2001 o Estado reconheceu esta comunidade como quilombola (ITESP, 2004), mas em função da existência de áreas particulares e da sobreposição do Parque Estadual de Jacupiranga nas áreas historicamente ocupadas pelos seus antecedentes a situação fundiária de André Lopes não está resolvida, ou seja, não foi emitido o título de terra para a sua Associação até 0 momento.

A comunidade de Sapatu foi reconhecida como comunidade quilombola em 2001, mas até o momento não foi regularizada sua situação fundiária, ou seja, a Associação de Sapatu ainda não recebeu a titulação da terra. A Associação dos Remanescentes de Quilombo de Sapatu foi criada em 1997 e atualmente conta com 98 associados.

A economia da comunidade é baseada na produção de banana e roça de subsistência. Há na comunidade uma escola, além de energia elétrica e água encanada. Existem 6 aposentados. Vivem hoje em Sapatu 82 famílias, segundo o censo de 2002 realizado pelo ITESP. Sapatu está localizada a 33Km da cidade de Eldorado, às margens da estrada (SP 165) de acesso que une os municípios de Eldorado e Iporanga -SP. A área territorial de Sapatu é de 3.711,625 hectares cuja malha fundiária apresenta-se complexa, isto é, está marcada por uma ocupação irregular e heterogênea, devido à existência de algumas áreas definidas como de pessoas "estranhas" à comunidade, não quilombolas (ITESP, 2000). Além deste fato, parte desta área foi sobreposta pelo Parque Estadual de Jacupiranga. 


\section{RESULTADOS E DISCUSSÃO}

"A realidade acontece quando a vemos; como a realidade acontece, depende de como a vemos". (Danah Zohar)

\subsection{Histórico de implantação da atividade nas comunidades estudadas}

Durante o período inicial do Projeto de Aproveitamento de Resíduos da Agroindústria da Banana no Vale do Ribeira, a área de Antropologia e Aproveitamento Artesanal buscou entrar em contato com os artesãos dessa região, através da Superintendência do Trabalho Artesanal de Comunidades (SUTACO), e resgatar as técnicas e matérias-primas artesanais tradicionalmente utilizadas, tais como o trançado feito com outras fibras (palha de milho e de taboa), além das cestarias de taquara e de cipó. Nesse período foi solicitado à SUTACO os cadastros de artesãos da região, mas os mesmos estavam desatualizados.

Foram então realizados no laboratório vários testes com a fibra de bananeira utilizando as técnicas de trançado já praticadas pelos artesãos do Vale, como também foram feitas adaptações para uso deste material na produção artesanal com o uso de tear, ou seja, na tecelagem.

Esse encontro de "saberes" resultou no desenvolvimento de protótipos com a fibra de bananeira, tais como: esteiras, cortinas, assentos de cadeiras, sandálias, bolsas, jogo americano e outros objetos de uso doméstico e pessoal, além de papel artesanal. Nessa etapa foi verificada a viabilidade da utilização da fibra de bananeira na confecção de produtos artesanais, e iniciado a 
fase do repasse deste conhecimento, através de cursos de capacitação para o uso desse tipo de fibra na atividade artesanal já presente na região do Vale do Ribeira.

Realizou-se então novos contatos com Prefeituras Municipais do Vale que congregavam o CODIVAR, órgãos governamentais como a SUTACO, Fundação Florestal e o ITESP e não governamentais como a Fundação Bradesco, Vitae Civilis dentre outras, para divulgação da nova modalidade de artesanato e para o repasse das técnicas de trabalho artesanal com a fibra de bananeira através de cursos de capacitação. Os cursos tinham os seguintes objetivos: a) capacitar as pessoas interessadas para o aproveitamento do resíduo da bananicultura como fonte de matéria prima na produção artesanal; b) fomentar o aproveitamento desse resíduo como uma estratégia de conservação ambiental, considerando que se trata de um material substituto para outras matérias-primas, tradicionalmente utilizadas na confecção de utensílios domésticos e que são coletadas na mata (cipós, taquaras e madeiras); c) estimular o resgate de técnicas artesanais tradicionais da região e d) estimular a prática da produção artesanal com fibra de bananeira como uma atividade complementar à agricultura de subsistência (Garavello et al, 1998).

No ano de 1997 foi realizado o primeiro curso (Figura 2 e 3.), na cidade de Iguape (SP), ministrado pelos técnicos do Projeto o Sr. Alziro Corazza e Vânia P. de Menezes. Após este primeiro curso, houve a divulgação do artesanato com fibra de bananeira em um evento na cidade de Registro (SP), no qual foram expostas todas as peças artesanais produzidas durante 0 curso. Outras cidades do Vale, através de suas prefeituras, também viabilizaram a realização desta capacitação em seus municípios, dentre elas a de Eldorado, em julho de 1997.

"(...) quando a gente foi para Iporanga e Eldorado (nas cidades) via Projeto Banana - a propaganda dos cursos foi realizadas "boca-a-boca". - todas as pessoas das instituições que estavam trabalhando na região do Vale do Ribeira ficaram sabendo do artesanato com fibra de bananeira... então se "formou uma grande teia..." (Alziro Corazza).

A divulgação dos cursos de capacitação nos municípios do Vale ocorreu "boa a boca", através das próprias pessoas da região e via técnicos das instituições governamentais e não governamentais locais, formando assim a "grande teia" referenciada por Alziro. Foi assim que, 
funcionários da Secretaria de Educação da Prefeitura da cidade de Miracatu (SP), entrou em contato com a SUTACO, solicitando a realização do curso em Miracatu. Tal solicitação foi concretizada e 0 artesão Alziro, juntamente com outros técnicos foram realizar o curso.

Ainda em 1997, através da SUTACO o mesmo artesão ministou o curso de capacitação para produção de artesanato com fibra de bananeira em duas comunidades quilombolas do município de Eldorado, a de André Lopes e a de Ivaporunduva. Vale ressaltar que nessa época, técnicos da SUTACO estavam realizando um levantamento das potencialidades artesanais existentes em vários dos municípios do Vale, dentre eles, o de Eldorado, e identificaram problemas sociais graves na localidade, como alcoolismo e prostituição infantil. Havia a necessidade urgente de se criar alternativas de trabalho para as comunidades rurais da região, em especial as comunidades quilombolas ali existentes e 0 artesanato com a fibra de bananeira poderia ser uma oportunidade "viável". No caso de Ivaporunduva o motivo foi porque "Ivaporunduva é o quilombo de referência (...)", seriam "questões políticas" explica Alziro.

No final do primeiro curso, ministrado em meados do mês de dezembro de 1997, os alunos dos cursos de capacitação das comunidades de Ivaporunduva e André Lopes, montaram uma barraca de bambu (confeccionada pelo Sr. Constantino, artesão de Ivaporunduva, que trabalha com madeira), na praça central de Eldorado para servir de local para a exposição das peças confeccionadas durante o curso: bolsas, tecidos, bonecos, jogos americanos, tudo com a fibra da bananeira.

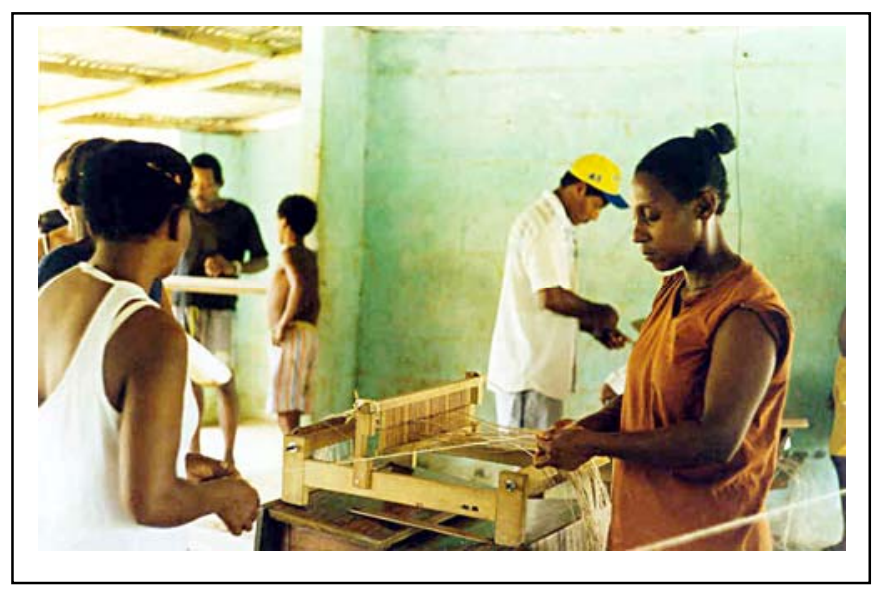

Figura 2 - Primeiro curso ministrado em Ivaporunduva. Artesã tecendo com a fibra de bananeira em tear de pente liço e de mesa 


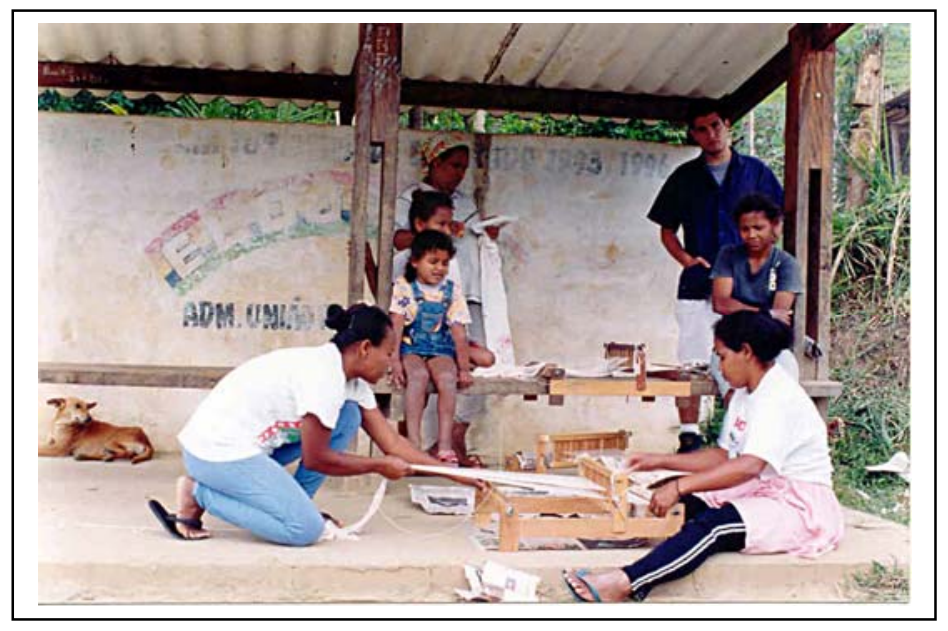

Figura 3 - Artesãs de Ivaporunduva durante o primeiro curso montando o tear

Outro aspecto que deve ser considerado como relevante no processo de disseminação dos cursos, foi a interlocução feita pelas religiosas ${ }^{18}$ da Paróquia de Eldorado com a equipe da ESALQ e as comunidades, em especial a de Ivaporunduva. A irmã Sueli, uma das religiosas mais envolvidas com as causas sociais e políticas das comunidades negras do Vale do Ribeira, teve papel fundamental na viabilização do primeiro curso em Ivaporunduva, como mediadora.

Vale dizer que a Igreja Católica, através dos trabalhos da Pastoral da Terra e da Mitra Diocesana de Registro muito antes do período da realização dos cursos, já vinham apoiando 0 movimento social de base das comunidades rurais do Vale. E também na elaboração de projetos e buscando fontes de financiamentos junto à Fundação Palmares, ao Governo Federal e a própria Igreja Católica para viabilização de trabalho de organização de base e melhoria social das comunidades rurais e quilombolas da região.

"(...) Para ir para Ivaporunduva era difícil, o pessoal da cidade não tinha relação com os líderes das comunidades quilombos, tinha muito preconceito, como até hoje existe... o pessoal de Ivaporunduva estava mais arisco, tinham muitos pesquisadores que tinham realizado pesquisas e nunca deram retorno para a comunidade..."(Alziro Corazza).

\footnotetext{
18 Por volta de 1985 chegaram na Pastoral do município de Eldorado as irmãs (freiras) Maria Sueli e Ângela Biagioni. Essas irmãs, após conhecerem a realidade rural do município e das comunidades rurais negras da região, sentiram a necessidade de que 0 eixo central de seus trabalhos em Eldorado seria a defesa das comunidades rurais do Vale contra a concretização do projeto de construção as barragens da Companhia Energética de São Paulo - CESP e da Companhia Brasileira de Alumínio CBA (Carril, 1995).
} 


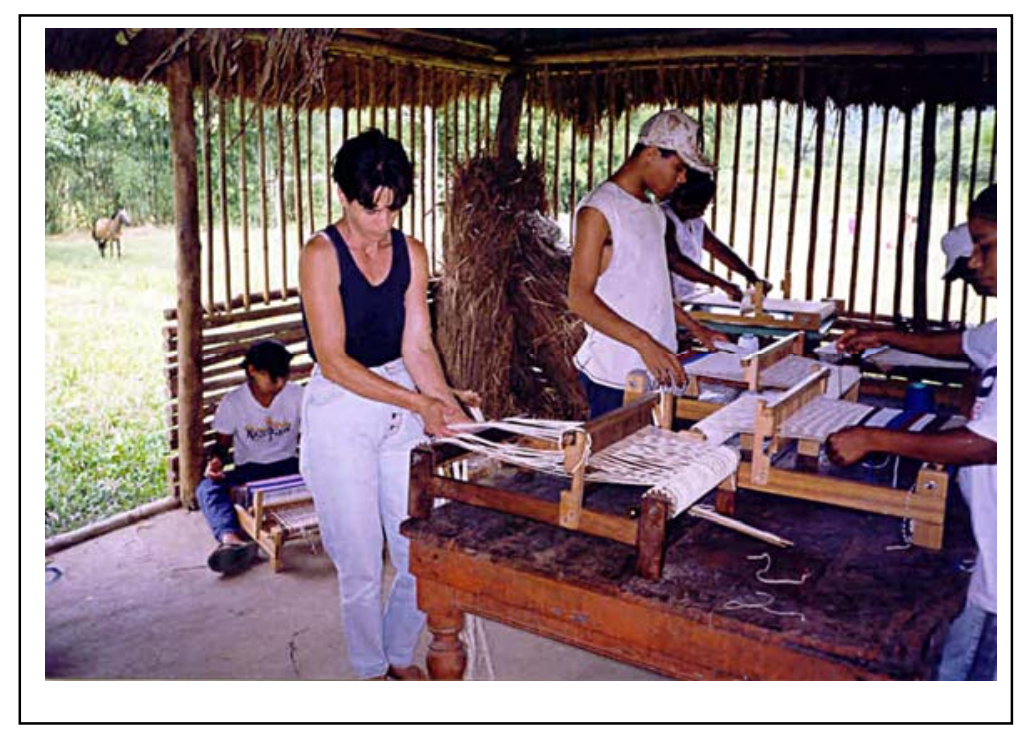

Figura 4 - Primeiro curso ministrado na comunidade de Sapatu. Teares de pente liço sendo preparados pelos artesãos para tecer com a fibra de bananeira

Na comunidade de Sapatu a viabilização do primeiro curso (Figura 4) se deu através da parceria informal entre a equipe da ESALQ, a Fundação Florestal (FF) e a Mitra Diocesana de Registro (SP).

No ano de 1998, a ESALQ fez contato com Fundação Florestal em São Paulo, com a finalidade de buscar novas parcerias com instituições que pudessem viabilizar a realização dos cursos de capacitação de artesanato utilizando a fibra de bananeira para comunidades rurais do Vale que não tinham sido capacitadas. Uma funcionária da FF, Sandra Guanaes que, há muito, já atuava junto às comunidades quilombolas vizinhas às Unidades de Conservação (UC) da região, buscando a viabilização de ações em conjunto como tais comunidades, que pudessem beneficialas, sem comprometer os objetivos dessas UC. Ainda no ano de 1998, na comunidade de Sapatu, ocorreu uma reunião com membros de todas as comunidades quilombolas de Eldorado, na qual Sandra Guanaes apresentou um mostruário de peças possíveis de serem confeccionadas com a fibra de bananeira, fornecido pela equipe da ESALQ. Nessa ocasião as comunidades de Ivaporunduva e André Lopes já haviam tido o primeiro curso de capacitação. Essa mesma funcionária da FF relata que durante essa reunião, alguns artesãos dessas comunidades falaram a respeito do artesanato tradicional, confeccionado com cipó timbó, cipó imbé, entre outros 
materiais da flora nativa. E mencionaram que desejavam reforçar 0 artesanato típico, produzido com cipó e taquara, por já existir certa comercialização desse tipo de produtos.

Percebe-se que já existia a vocação da produção artesanal nas comunidades estudadas. A partir dessa ocasião, os artesãos locais passaram a discutir com os técnicos da FF a possibilidade de organizarem essa atividade. Foi então elaborada uma proposta de cursos de capacitação para essas comunidades, dentre eles, o do artesanato de fibra de bananeira, que através da Mitra Diocesana de Registro, seria apresentada à Fundação Palmares, com a finalidade de captar recursos financeiros para sua execução. De acordo com informação de técnicos da FF, o financiamento solicitado não foi obtido.

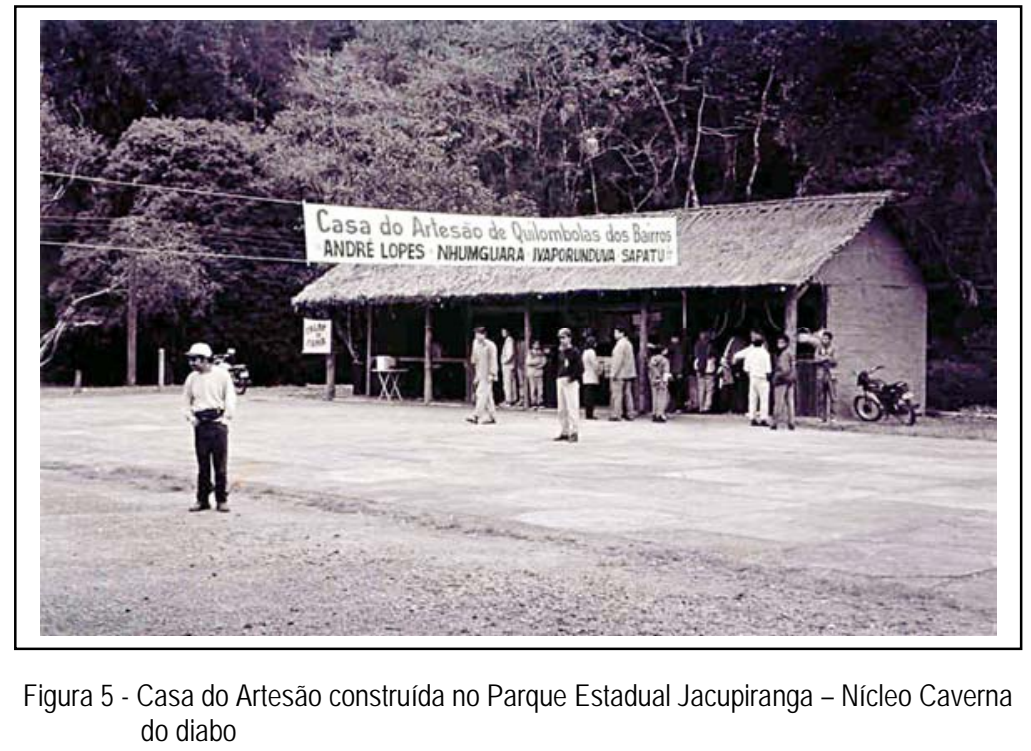

No ano de 2000, o Instituto Florestal (IF), deu apoio à equipe da ESALQ, permitindo a realização de mais de um curso de capacitação artesanal. Este foi realizado no Parque Estadual de Jacupiranga - Núcleo Caverna do Diabo, onde também participaram pessoas de outras comunidades quilombolas, além de Ivaporunduva, André Lopes e Sapatu, a de Nhunguara, São Pedro e Pedro Cubas, vizinhas das três citadas primeiramente. A administração do Parque além desse apoio, cedeu um local neste Núcleo para construção de um quiosque para a comercialização dos produtos artesanais feitos pelos artesãos das comunidades quilombolas localizadas no entorno do Parque. Este espaço foi batizado como a "casa do artesão" e construído pelos próprios artesãos (Figura 5). 
Vale ressaltar que após a capacitação, o Instituto de Terras do Estado de São Paulo (ITESP) deu auxílio técnico e de infra-estrutura para algumas comunidades, dentre elas a de Sapatu e André Lopes. Desde 2000, técnicos dessa instituição tem feito acompanhamento da atividade artesanal nessas comunidades, além de ter viabilizado a construção de benfeitorias destinadas ao uso dos artesãos. No ano de 2001 para 2002 foram construídas nas comunidades de André Lopes (Figura 6) e de Sapatu (Figura 7) duas estruturas para produção e venda do artesanato de bananeira.

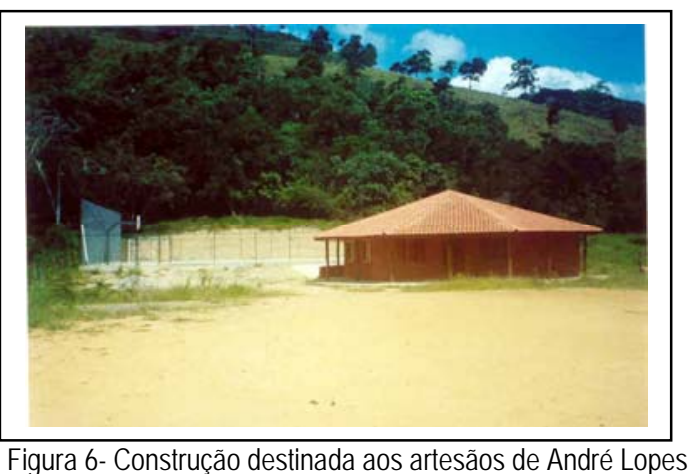

Figura 6- Construção destinada aos artesãos de André Lopes

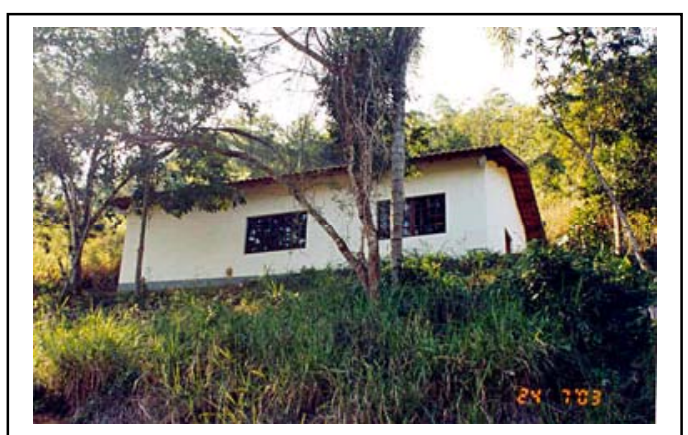

Figura 7 - Construção destinada aos artesãos de Sapatu

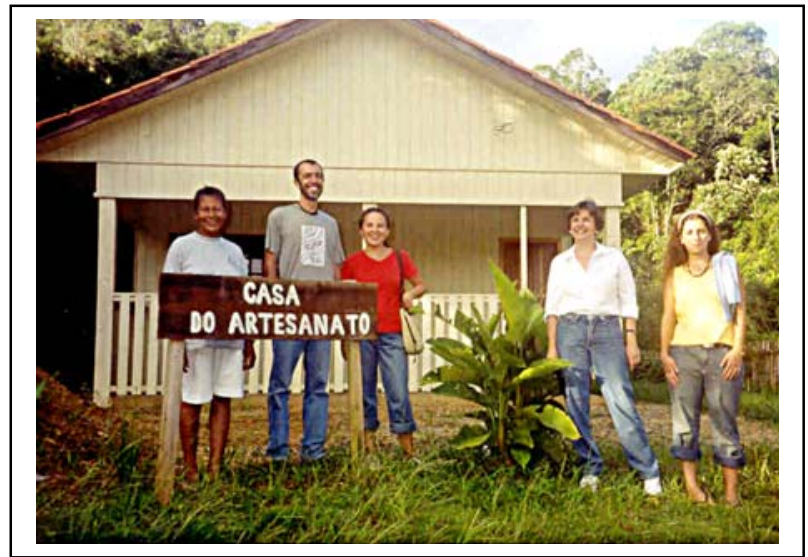

Figura 8- Casa do Artesanato de Ivaporunduva

No caso da comunidade de Ivaporunduva (Figura 8), foi o Instituto Sócioambiental (ISA) que viabilizou a construção de uma sede exclusivamente para o uso dos artesãos, batizada de a 
Casa do Artesanato e que têm sido utilizada por eles como local de comercialização das peças artesanais.

Nas comunidades de Ivaporunduva e André Lopes foram ministrados no total três cursos entre os anos 1997 a 2000 e na comunidade de Sapatu foram dois cursos.

No segundo curso ministrado em Sapatu, participaram 23 pessoas da comunidade de Ivaporunduva - as mesmas que participaram do primeiro curso. Da comunidade de André Lopes participaram 3 pessoas iniciantes e 9 que tinham participado do curso de 1997. No caso de Sapatu, o primeiro curso ministrado para o público desta comunidade foi em 1998, no qual participaram 18 pessoas. Foram capacitadas nos anos de 1997 e 1998 um montante de 53 pessoas, sendo 23 de Ivaporunduva, 12 de André Lopes e 18 de Sapatu.

Na Tabela 1, é possível visualizar: (1) a quantidade de pessoas que participaram do primeiro curso de capacitação para uso do resíduo da bananeira na atividade artesanal nas comunidades de Ivaporunduva e André Lopes, realizados em novembro e dezembro de 1997; (2) o número de participantes de cada uma das comunidades envolvidas; (3) o número de pessoas das várias comunidades quilombolas que estiveram envolvidas no segundo curso, ministrado em novembro de 1998 em Sapatu. Essas informações foram obtidas após análise de relatórios internos do "Projeto de Aproveitamento de Resíduos da Agroindústria da Banana no Vale do Ribeira".

Tabela 1. Número de participantes dos cursos de capacitação nos anos de 1997 e 1998.

\begin{tabular}{|c|c|c|c|c|c|}
\hline Comunidades & $\begin{array}{l}n^{\circ} \text { de homens } \\
\text { em } 1997\end{array}$ & $\begin{array}{l}n^{\circ} \text { de mulheres } \\
\text { em } 1997\end{array}$ & $\begin{array}{c}n^{\circ} \text { de homens } \\
\text { em } 1998\end{array}$ & $\begin{array}{l}n^{\circ} \text { de mulheres } \\
\text { em } 1998\end{array}$ & $n^{\circ}$ total de participantes/ \\
\hline Ivaporunduva & 17 & 6 & * & * & 23 \\
\hline André Lopes & 1 & 8 & * & 3 & 12 \\
\hline Sapatu & ** & ** & 7 & 11 & 18 \\
\hline Total/sexo & 18 & 14 & 7 & 14 & 53 \\
\hline
\end{tabular}

* ausência de participantes no curso de 1998.

** ausência de participantes no curso de 1997.

$\mathrm{Na}$ Tabela 2, observa-se que no terceiro curso de capacitação artesanal com fibra de bananeira, realizado em dezembro de 2000, participaram um total de 38 pessoas, sendo que: 9 pessoas da comunidade de Ivaporunduva eram iniciantes - estavam participando do curso pela 
primeira vez; 5 pessoas da comunidade de André Lopes também eram iniciantes. Da comunidade de Sapatu, todos os participantes já haviam feito o curso de 1998. No geral, participaram do curso 38 alunos, dos quais 14 eram iniciantes (novos alunos); 7 participantes declararam estar fazendo o curso pela segunda vez e 17 participantes declararam estar participando do curso pela terceira vez.

Tabela 2. Número de participantes no curso de capacitação de 2000

\begin{tabular}{|c|c|c|c|c|c|c|c|}
\hline \multirow[t]{2}{*}{ Comunidades } & \multicolumn{2}{|c|}{$\begin{array}{c}n^{\circ} \text { de participantes } \\
\text { iniciantes }\end{array}$} & \multicolumn{2}{|c|}{$\begin{array}{c}n^{\circ} \text { de participantes } \\
\text { pela segunda vez }\end{array}$} & \multicolumn{2}{|c|}{$\begin{array}{l}n^{\circ} \text { de participantes } \\
\text { pela terceira vez }\end{array}$} & \multirow{2}{*}{$\begin{array}{c}n^{\circ} \text { total de } \\
\text { participantes/ } \\
\text { comunidade }\end{array}$} \\
\hline & homens & mulheres & homens & mulheres & homens & mulheres & \\
\hline Ivaporunduva & 2 & 7 & * & * & 8 & 3 & 20 \\
\hline André Lopes & 1 & 4 & * & 1 & 1 & 5 & 12 \\
\hline Sapatu & * & * & 2 & 4 & * & * & 6 \\
\hline $\begin{array}{c}\text { Total de } \\
\text { participantes }\end{array}$ & 3 & 11 & 2 & 5 & 9 & 8 & 38 \\
\hline
\end{tabular}

Depois do último curso ministrado pelo Sr. Alziro, em 2000, o ISA patrocinou mais dois cursos. Estes foram dados por um artesão da própria comunidade, o Sr. César. Ele aprendeu a técnica de se trabalhar com a fibra nos cursos dados pela ESALQ e agora é chamando para dar curso fora da comunidade também. Ele formou em Ivaporunduva aproximadamente 8 pessoas, fora as 32 pessoas já capacitadas.

$\mathrm{Na}$ Tabela 3, estão representados os dados numéricos referentes às pessoas das comunidades quilombolas de Ivaporunduva, André Lopes e Sapatu que foram capacitadas a fazer 0 artesanato com fibra de bananeira nos cursos ministrados pela ESALQ, e o número de pessoas que estão trabalhando com este artesanato atualmente.

Tabela 3. Quantidade de homens e mulheres capacitados nos cursos e a quantidade de pessoas que atualmente fazem 0 artesanato com fibra de bananeira

\begin{tabular}{lllll}
\hline Comunidades & $\begin{array}{l}n^{\circ} \text { de homens } \\
\text { capacitados }\end{array}$ & $\begin{array}{l}n^{\circ} \text { de mulheres } \\
\text { capacitadas }\end{array}$ & $\begin{array}{l}n^{\circ} \text { de homens que } \\
\text { trabalham com } \\
\text { artesanato de banana } \\
\text { atualmente }\end{array}$ & $\begin{array}{l}n^{\circ} \text { de mulheres que } \\
\text { trabalham com } \\
\text { artesanato de banana } \\
\text { atualmente }\end{array}$ \\
\hline Ivaporunduva & 19 & 13 & 2 & 15 \\
André Lopes & 17 & 15 & 0 & 1 \\
Sapatu & 7 & 11 & 0 & 6 \\
\hline
\end{tabular}


Os dados da Tabela acima permitem concluir que, dentro das referidas comunidades, Ivaporunduva hoje é a que tem o maior número de pessoas envolvidas com a atividade do artesanato de fibra de bananeira.

Concebido para atender a uma demanda do CODIVAR, o "Projeto de Aproveitamento do Resíduo da Bananicultura no Vale do Ribeira", através dos cursos de capacitação, parece ter contribuído significativamente para a valorização de uma atividade que muitas pessoas das comunidades quilombolas já tinham por vocação, que é a expressão artesanal. Conforme pode ser observado nesse processo histórico, o processo de viabilização dos cursos de artesanato com fibra de bananeira foi uma articulação entre as comunidades e as instituições que na época estavam em contato direto com a problemática vivida por essas comunidades, com relação à melhoria da qualidade de vida dessas pessoas.

As comunidades quilombolas não atribuíam às peças artesanais que produzidas com matéria prima retirada da mata a denominação de "artesanato". Não tinham como prática costumeira confeccionar estas peças para uso de decoração. De fato, o que é confeccionado e visto nas casas dos entrevistados, são utensílios de uso doméstico como: tipiti, peneira, pá de madeira. Com a intervenção dos cursos de capacitação com fibra de bananeira, o termo "artesanato" passa a ser visto pelas comunidades como um apelo ao comércio, sendo então incorporado por algumas pessoas que já faziam as peças com materiais obtidos da mata.

\subsubsection{A assimilação da técnica}

Nas comunidades quilombolas de eldorado, por ocasião dos primeiros contatos com os pesquisadores da ESALQ, observou-se que já existiam artesãos que utilizavam matérias - primas da flora nativa, como cipós, madeiras e taquara, como uma alternativa de geração de renda, além de produzirem alguns utensílios domésticos de uso cotidiano, como esteiras, abanadores e pilões. A introdução do artesanato com o uso da fibra de bananeira se deu através da técnica repassada durante os cursos de capacitação, dando início ao processo de aprendizagem com esse tipo de matéria prima.

Segundo Alziro Corazza, quando ele foi dar o curso em Ivaporunduva, algumas pessoas relataram já conhecerem o tear de prego. Instrumento utilizado na tecelagem, com o qual é 
possível fazer uma trama utilizando tanto linhas sintéticas como fibras vegetais e bastante simples de ser confeccionado, sendo necessário apenas um esquadro de madeira e pregos.

De acordo com os relatos, as técnicas que os artesãos aprenderam nos cursos de capacitação, nos anos de 97, 98 e 2000 foram a extração de palha e da fibra do tronco da bananeira, a fiação e tecelagem desse material, utilizando teares (Figura 9) de pente lico de mesa e roca, informações detalhadas encontram-se no "Manual de produção" publicado pela ESALQ19. Essas técnicas foram assimiladas com muita facilidade pelos participantes. A descrição abaixo permite melhor compreender o processo de repasse da técnica:

"Eu ensinei a extração da palha e fibra de bananeira e a tecer no tear. O pessoal gostou porque esta matéria prima é disponível e a ferramenta necessária, que é o tear, não era difícil de se aprender a trabalhar ..." (Alziro).

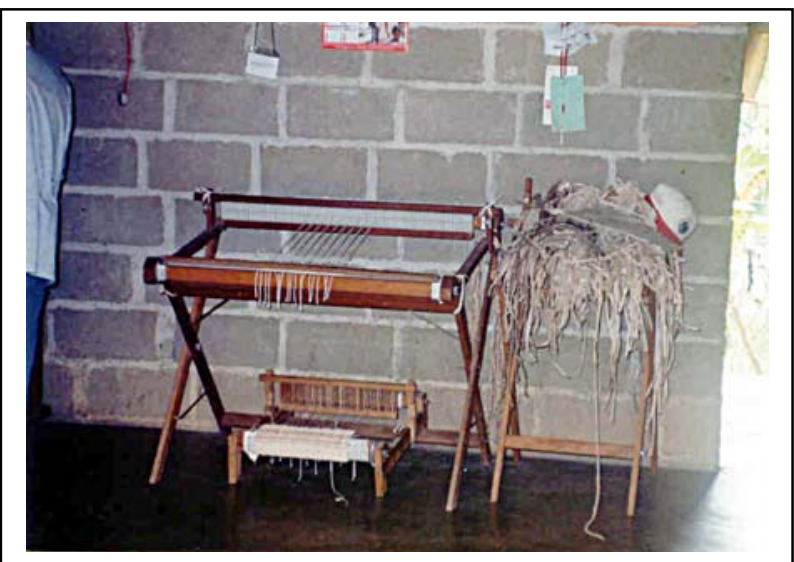

Figura 9 - Tear de pente liço de cavalete e tear de mesa (no chão). Ao lado direito da foto fibras de bananeiras prontas para serem tecidas

A técnica de extração da fibra de bananeira, consiste em corte manual do tronco (Figura 10), retirada das bainhas dos troncos (Figura 11), cortes dessas em tiras (Figura12) e a secagem das mesmas ao sol (Figura 13). Na seqüência foi ensinada a técnica de tecer com tear, a qual foi transmitida inicialmente utilizando como "matéria prima" o fio barbante, para que os alunos

${ }^{19}$ GARAVELLO,M.E.P.E. coord. A palha e o fio da bananeira. Manual de produção. ESALQ/USP, 1999. 
tivessem o primeiro contato com a técnica de tecelagem em tear, em seguida foi ensinado tecer , utilizando a fibra de bananeira (Figura 14 e 15).

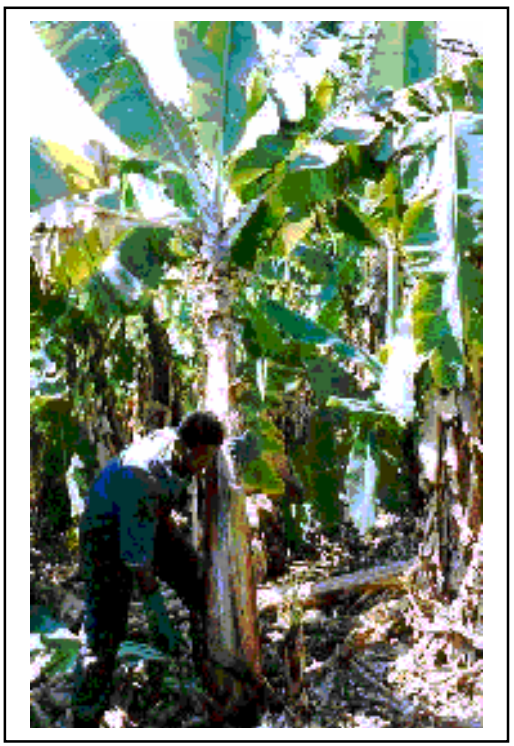

Figura 10 - Corte do tronco de bananeira 


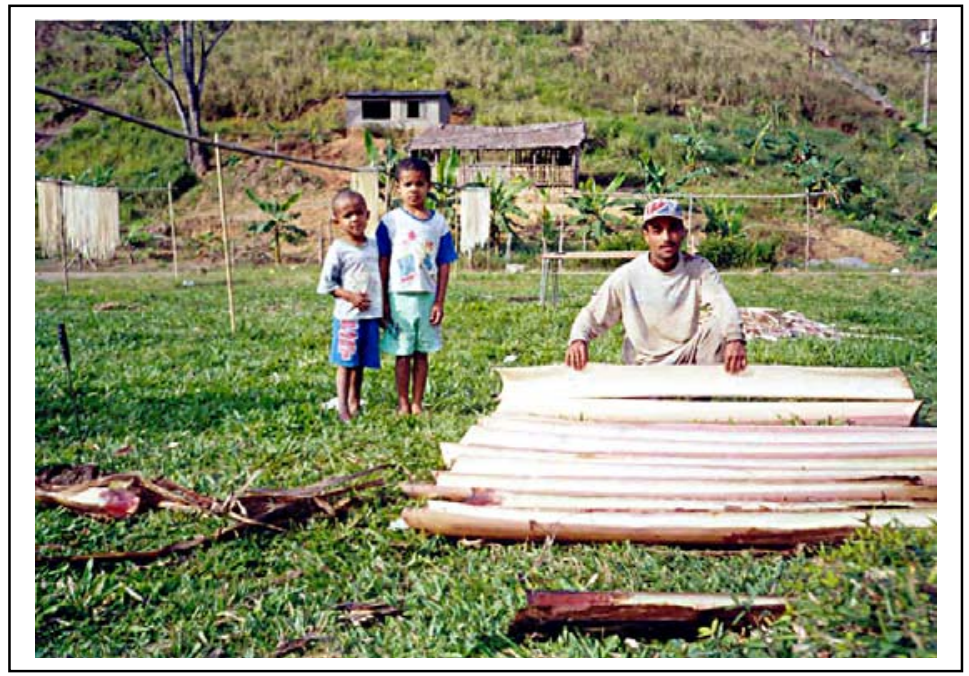

Figura 11 - Troncos de bananeira já cortados e suas bainhas sendo separadas por um artesão de André Lopes

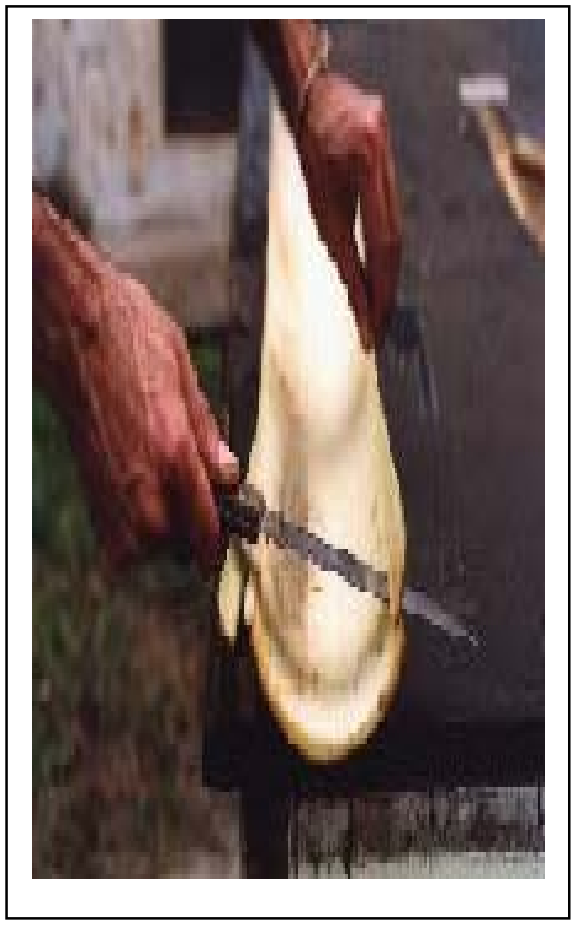

Figura 12 - Corte da bainha em tiras

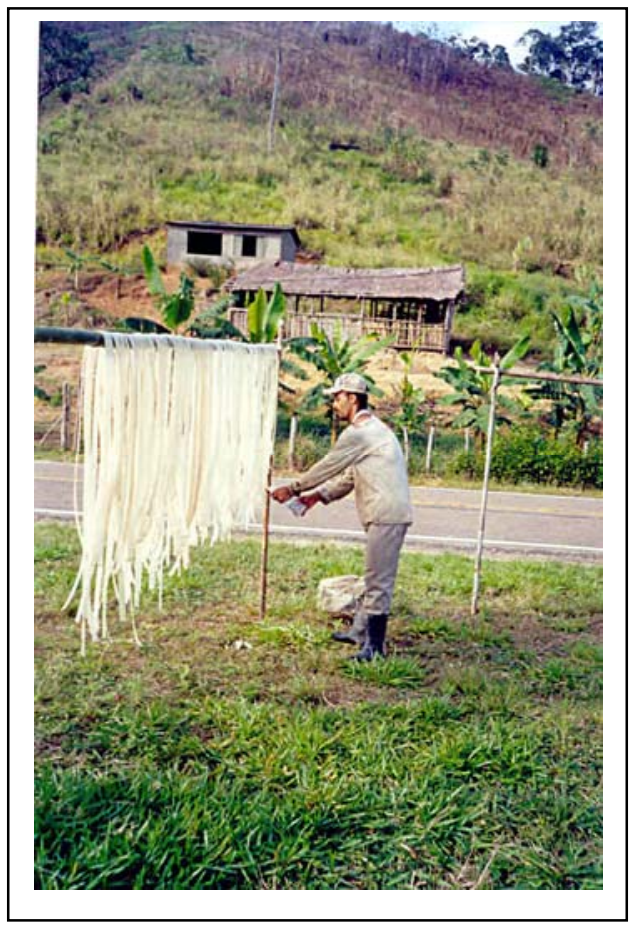

Figura 13 - Artesão pendurando as tiras retiradas bainhas dos troncos de bananeira para secar ao col 


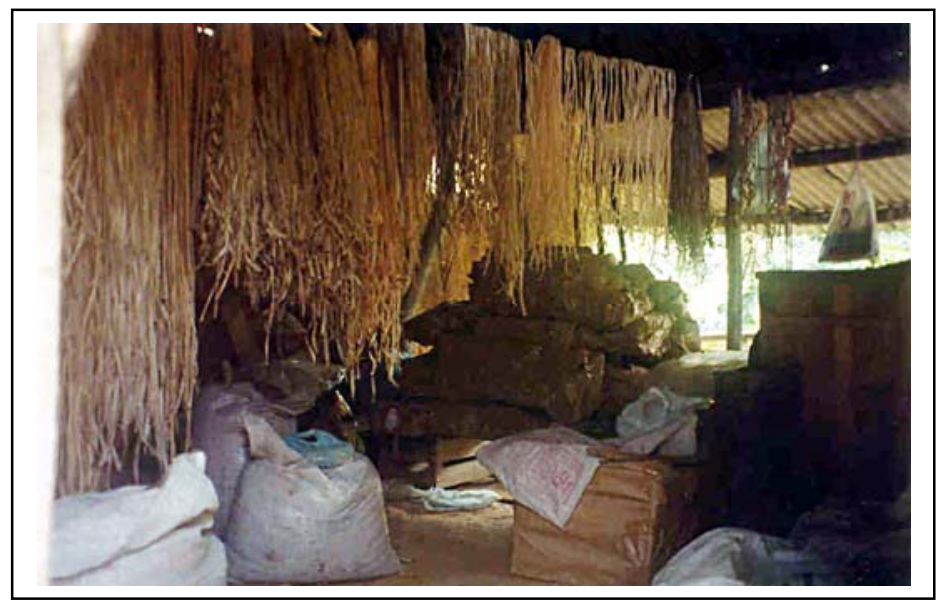

Figura 14 - Armazenagem das tiras de fibras de bananeira em um paiol da casa de uma artesã de Sapatu

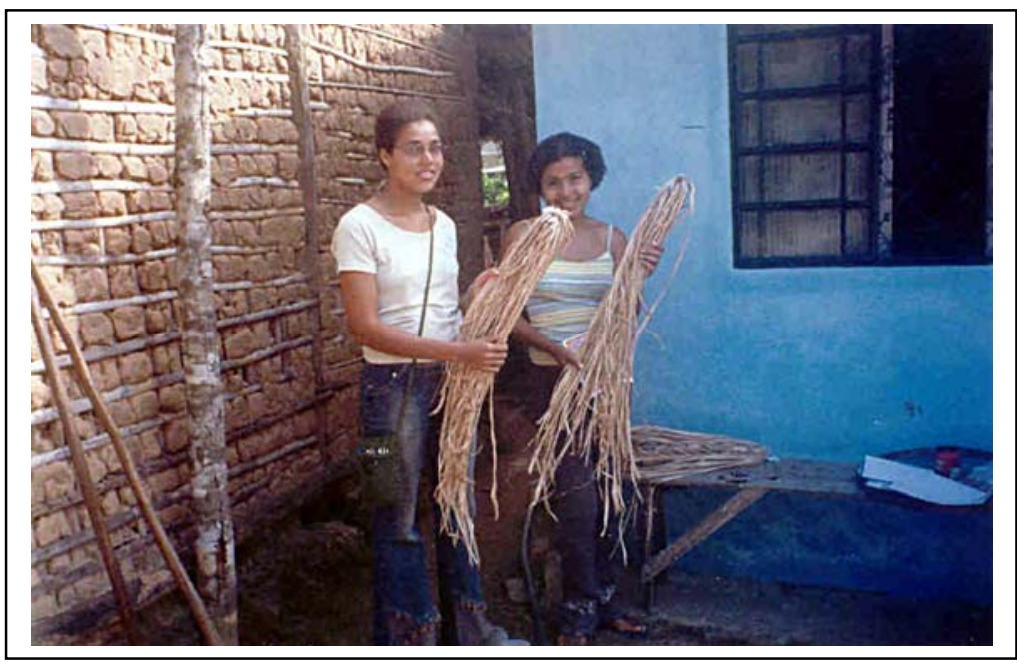

Figura 15 - Artesãs de Sapatu com as tiras da palha de bananeira já secas e prontas para serem tecidas 


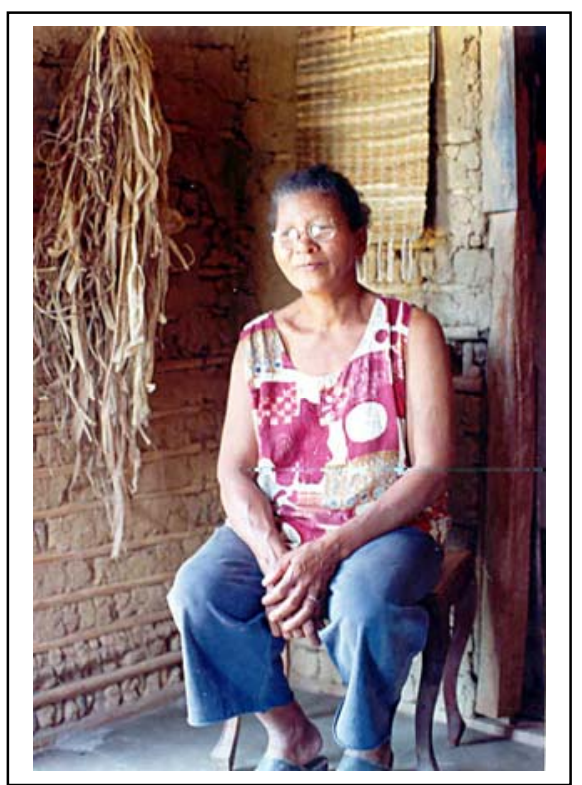

Figura 16- Artesã de Ivaporunduva. A esquerda da foto visualizase um maço de palhas de bananeira armazenada e a fundo uma peça pronta

Com o uso dos teares os alunos do curso aprenderam a confeccionar tecidos, ou seja, tapetes, jogo americano com o uso da fibra (Figura 16,17 e 19). Já no caso da técnica do trançado, alguns dos alunos já trabalhavam com tal técnica. Foi repassado que com o trançado (Figura 17) seria possível confeccionar alças para as bolsas. A técnica do ponto de macramê com a fibra de bananeira também foi ensinada para que pudessem confeccionar pulseirinhas e cintos. 


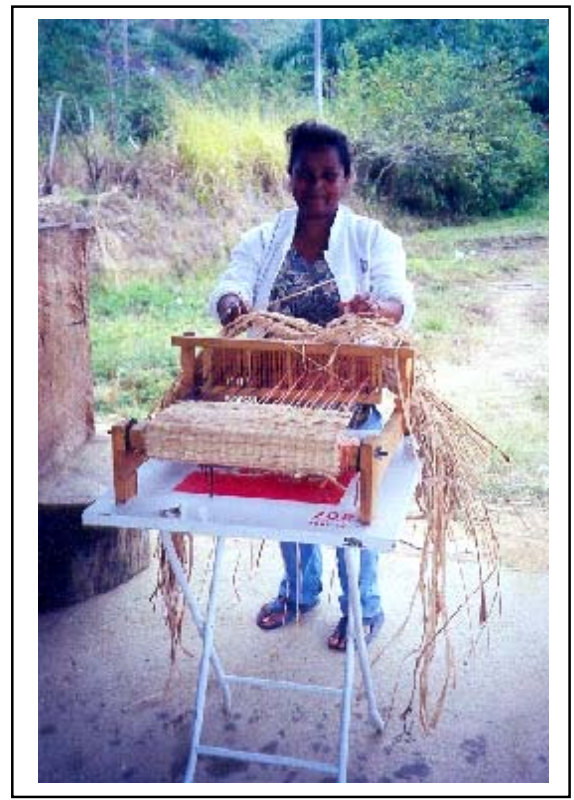

Figura 17 - Artesã de André Lopes tecendo

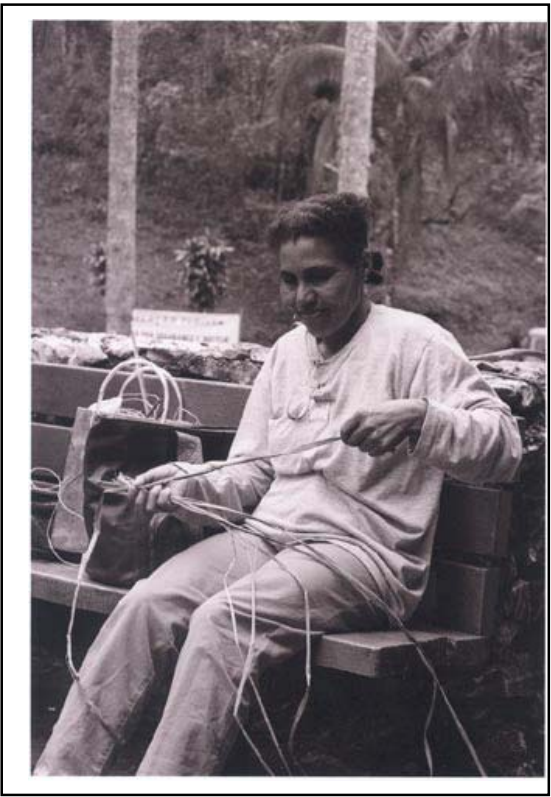

Figura 18 - Artesã de Sapatu fazendo trança com tiras de palha de bananeira

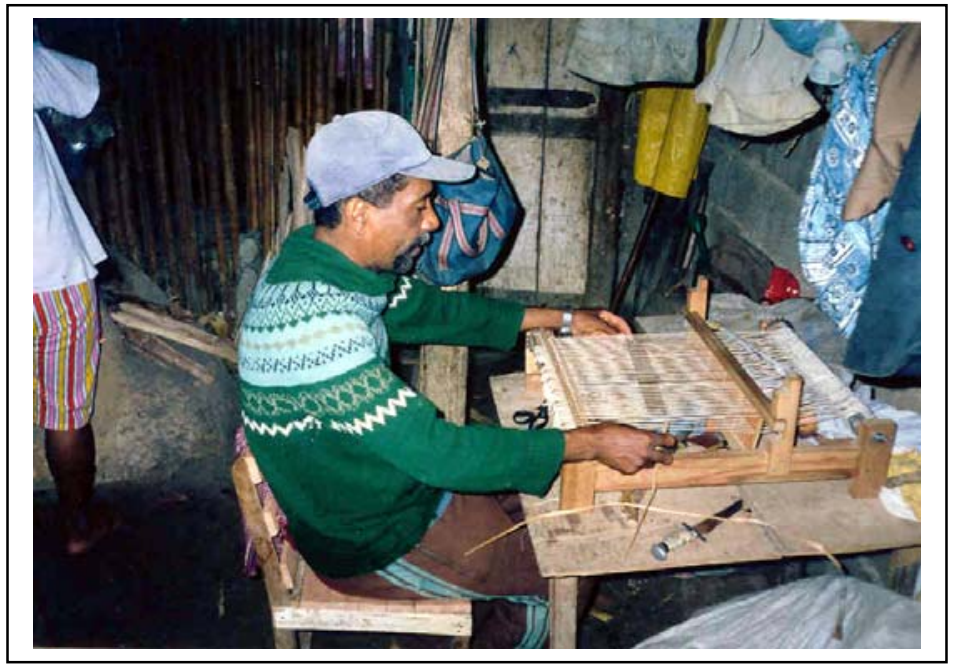

Figura 19 - Artesão de Ivaporunduva tecendo 
Após o primeiro curso, ministrado para as comunidades de Ivaporunduva e André Lopes, a SUTACO viabilizou no ano de 1998 alguns teares para ambas as comunidades, para dar continuidade à atividade artesanal com fibra de bananeira.

Em 2003, a Sociedade Civil Irmãs da Santa Cruz e da Mitra Diocesana de Registro providenciaram alguns teares e materiais necessários para se trabalhar na produção artesanal com fibra de bananeira, tais como: linhas e barbantes de algodão. Segundo o Sr. Alziro, o mesmo levou 11 teares para as ambas as comunidades.

No caso da comunidade de Sapatu, a artesã D. Esperança relata que no final de 98, todas as pessoas que tinham feito o curso receberam um tear. Os primeiros teares que as comunidades receberam foram confeccionados pelo próprio artesão do "Projeto de Aproveitamento do Resíduo da Bananicultura no Vale do Ribeira", e os doados para os artesãos, após o ano de 1998, foram teares com cavalete.

Sônia, artesã, explica que no ano de 2003, a Associação de Sapatu conseguiu 30 teares com cavalete. Ela explica que essa aquisição foi via um pequeno projeto elaborado com auxílio da irmã Sueli. Como havia pessoas de outras comunidades que também queriam teares, eles foram dividimos entre as comunidades de André Lopes, São Pedro, Núcleo Nhunguara e Pedro Cubas.

A artesã de Sapatu, durante uma conversa descreve a técnica por ela aprendida durante 0 curso:

"No curso aprendi a fazer só tapete. Demorou para eu aprender a tecer no tear, enquanto outras pessoas fizeram outras peças durante o curso, eu fiz somente duas. Mas até hoje eu faço artesanato e as pessoas que fizeram bastante peças no curso pararam de fazer" (Sônia).

Sônia relata ainda que baseada na técnica aprendida fez adaptações até confeccionar uma peça na forma de bolsa: "(...) primeiro, comecei a dobrar o tecido tipo tapete e não colocava as laterais, só dobrava e costurava, mas não dava para colocar quase nada dentro da bolsa, não cabia grande coisa, depois fui melhorando até sair uma bolsa de tamanho bom. A alça da bolsa fazia tipo trança, com a palha de bananeira".

Cabe salientar que além de Sônia, várias artesãs relataram que confeccionaram outras peças além das ensinadas no curso, como por exemplo, o tingimento da fibra de bananeira, 
utilizando corantes feitos com matérias-primas naturais (Tabela 4). Ainda com relação ao tingimento da fibra, algumas artesãs relataram que já tinham utilizado tintas químicas, tinta de tecido e tinta xadrez, mas que não estavam usando no momento.

Tabela 4. Tipos de peças artesanais produzidas com a fibra de bananeira, seus acessórios e corantes naturais.

\begin{tabular}{|c|c|c|c|}
\hline $\begin{array}{l}\text { Tipos de peças produzidas } \\
\text { com a fibra de bananeira }\end{array}$ & $\begin{array}{c}\text { Matérias -primas vegetais } \\
\text { usadas como adornos das } \\
\text { peças produzidas com a fibra } \\
\text { de bananeira }\end{array}$ & $\begin{array}{c}\text { matérias -primas vegetais } \\
\text { usadas como corantes } \\
\text { naturais da fibra de } \\
\text { bananeira }\end{array}$ & $\begin{array}{c}\text { materiais não vegetais } \\
\text { utilizados na confecção das } \\
\text { peças com a fibra de } \\
\text { bananeira }\end{array}$ \\
\hline Bolsas* & Capiá (semente) & Urucum & Barbante de algodão \\
\hline Jogo americano* & Guapiruvú (semente) & Alçafrão & Linha de nilon \\
\hline Pulseiras & Olho-de-cabra (semente) & Folha de maracujá & Lã \\
\hline Caminho de mesa & Taquara & 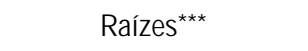 & botões \\
\hline \multicolumn{4}{|l|}{ Chapéu ${ }^{\star \star}$} \\
\hline \multicolumn{4}{|l|}{ Cortina** } \\
\hline \multicolumn{4}{|l|}{ Porta retrato** } \\
\hline \multicolumn{4}{|l|}{ Chinelo ${ }^{\star \star}$} \\
\hline \multicolumn{4}{|l|}{ Caxepô com tampa } \\
\hline \multicolumn{4}{|l|}{ Cestos ${ }^{\star \star}$} \\
\hline \multicolumn{4}{|l|}{ Porta moeda** } \\
\hline \multicolumn{4}{|l|}{ Cinto $^{\star \star}$} \\
\hline \multicolumn{4}{|l|}{ Porta bijouteria** } \\
\hline Tapetes ${ }^{\star \star}$ & & & \\
\hline
\end{tabular}

Nas comunidades de Sapatu e Ivaporunduva existem artesãs que tecem com a própria palha de bananeira de tonalidades de cores diferentes, criando formas de desenhos diferentes ao tecer (Figura 20 e 21). Do mesmo modo que há artesãs que adaptaram a técnica de tecer tapetes e confeccionaram bolsas do tipo redondas, outras utilizaram a técnica de trançado ensinada, adaptaram-na e confeccionaram peças como descanso de panelas e caixinhas trançadas (Figura 22 e 23).

Essas adaptações demonstraram como o artesanato começou a ganhar identidade própria, ou seja, quando os artesãos começaram a reunir o que foi ensinado e o que já era praticado. 


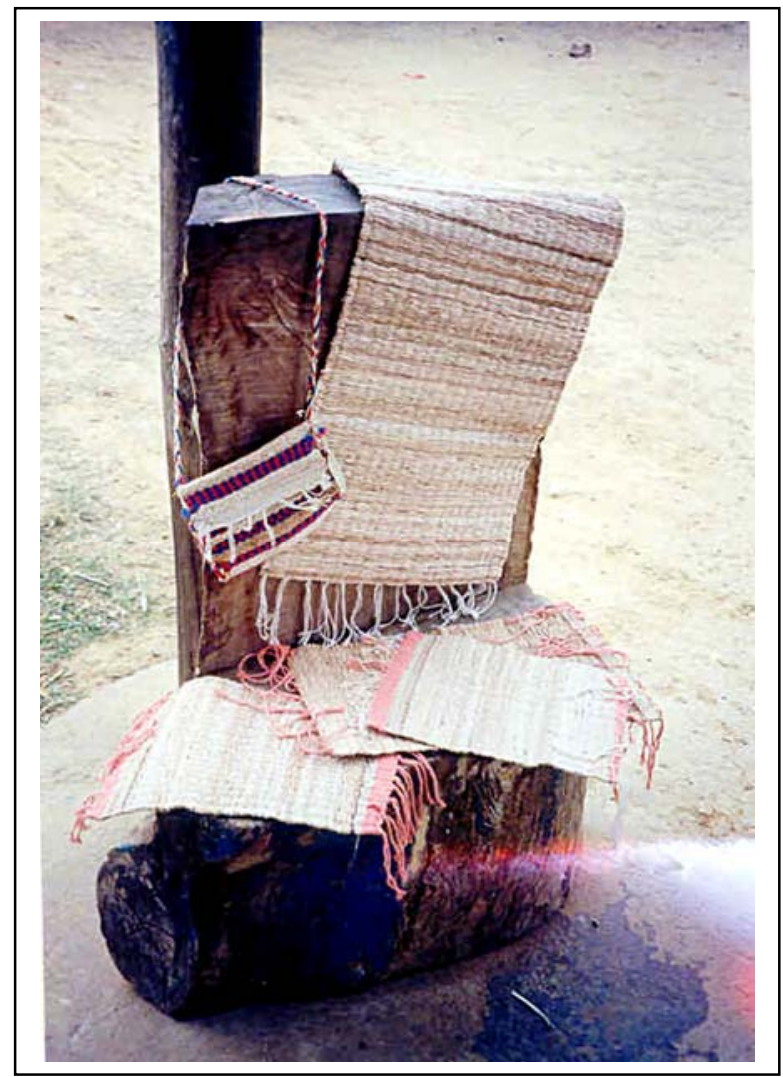

Figura 20. Peças confeccionadas pelas artesãs

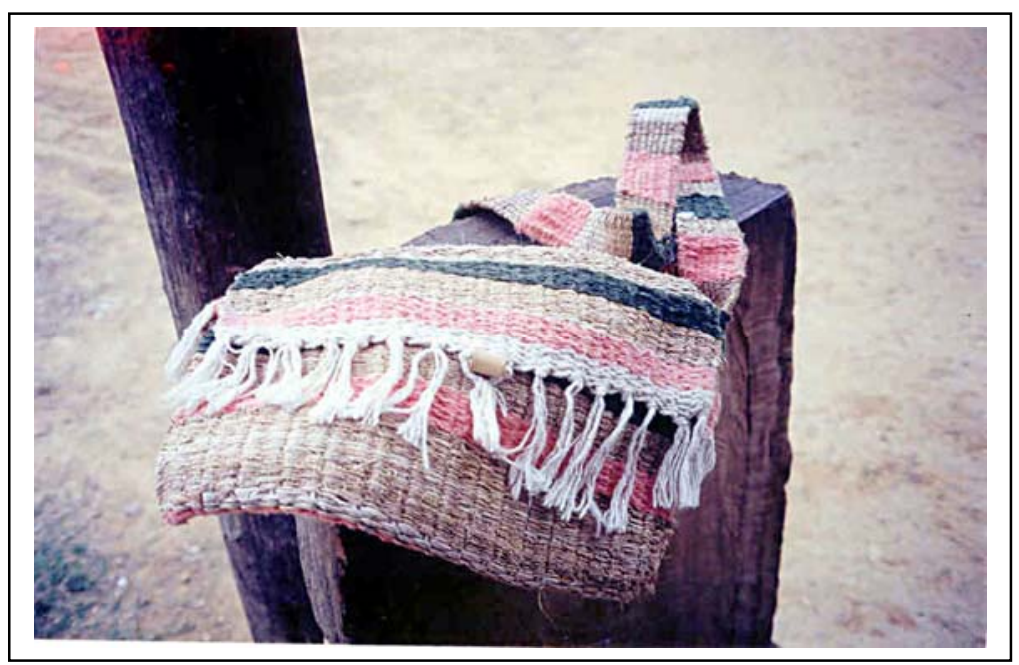

Figura 21. Bolsa de fibra de bananeira confeccionada por uma artesã. Detalhes coloridos, tingimento com corante artificial 


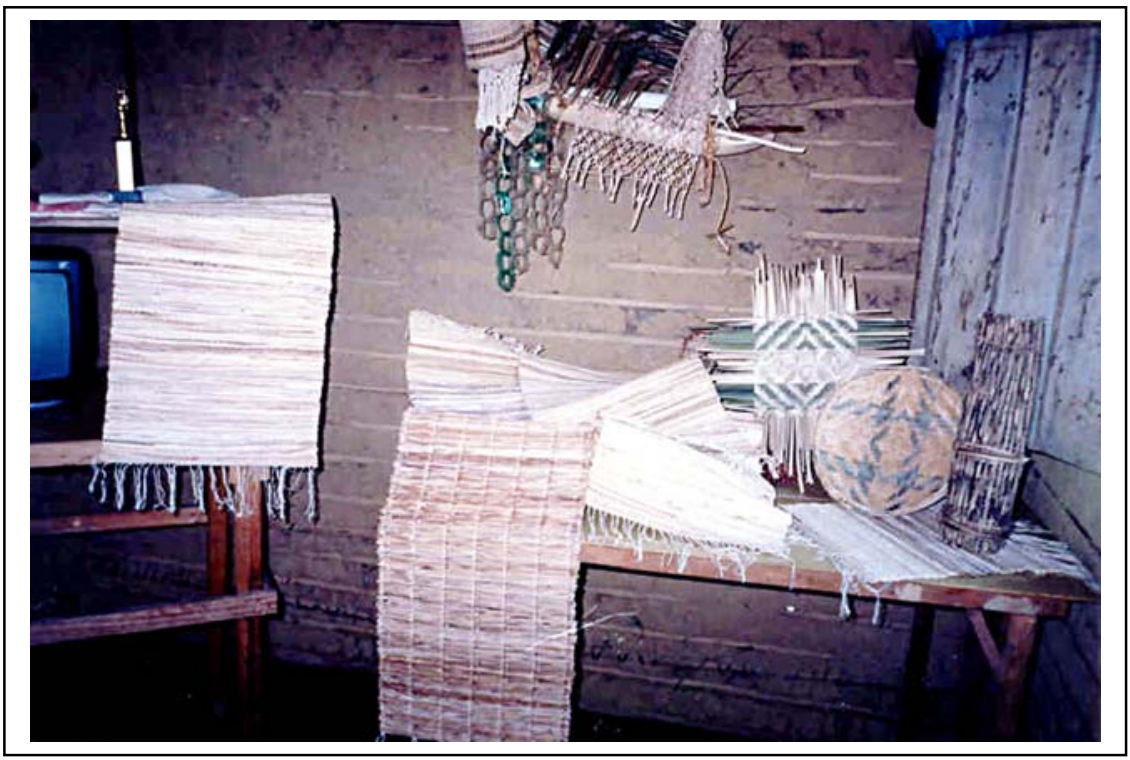

Figura 22. Na sala da casa de uma artesã, peças feitas de fibra de bananeira. Do lado esquerdo da foto um caminho de mesa sobre a televisão, e do lado direito jogos americanos e tapetes

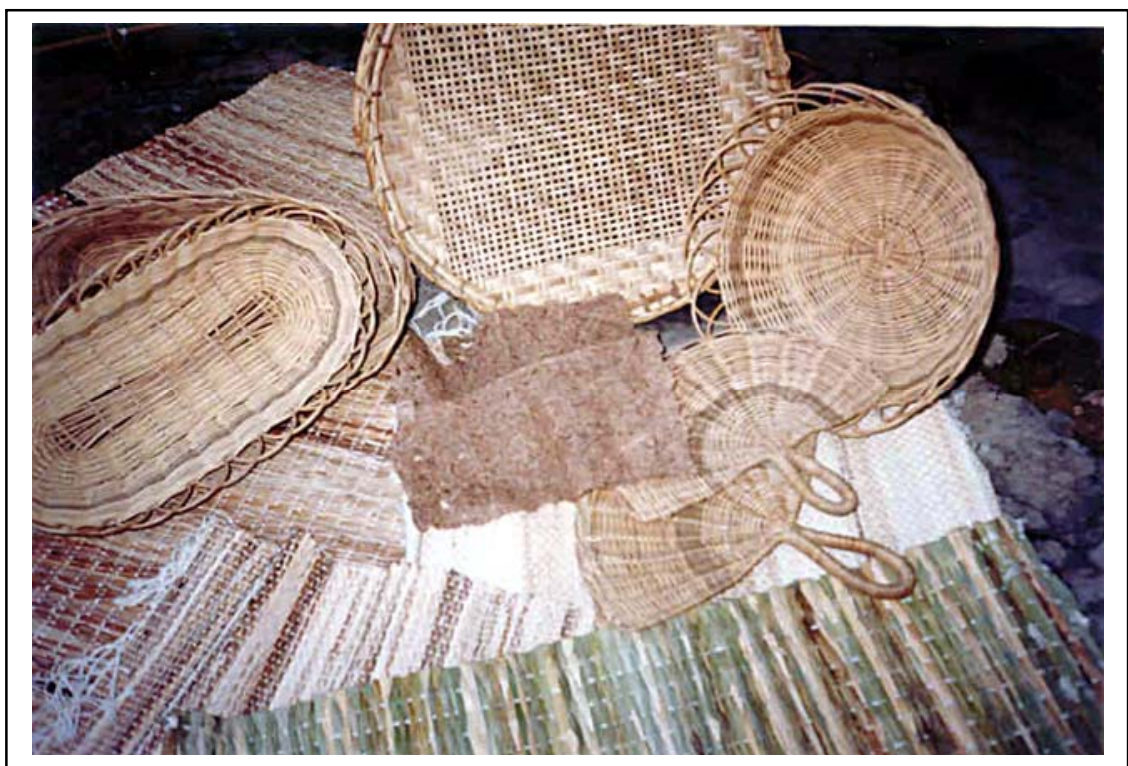

Figura 23. Peças feitas de fibra de bananeira, e algumas peneiras feitas de taquara 
Nas comunidades estudadas, muitas pessoas ainda utilizam o calendário lunar para coleta de madeira, corte de taquara, cipós e outros recursos vegetais, pois consideram que coletando esses materiais na lua minguante, eles têm maior durabilidade, resistindo melhor ao ataque de insetos. Relata Sônia, artesã de Sapatu que tira a palha na lua minguante porque não dá a broquinha. Todas as artesãs entrevistadas afirmaram que preferencialmente retiram a fibra de bananeira na lua minguante para evitar 0 ataque de inseto.

Pode-se afirmar que, o "artesanato" nas comunidades estudadas sempre fez parte da cultura local. Assim, exemplifica Paulo, de Ivaporunduva, ao relatar o que sua mãe fazia:

"(...) na maioria das vezes minha mãe tecia a esteira de taboa e tinha gente na comunidade que vendia uma peça ou outra. Às vezes uma pessoa que sabia fazer pilão fazia para outra família, e podia estar beneficiando um arroz e pilando café". Neste relato é possível perceber que, há muito, já havia uma troca de produtos artesanais dentro da comunidade, e, também, fora dela, quando ainda, as peças não tinham finalidade decorativa, e sim, utilitária, como no caso da esteira de taboa (Paulo- Ivaporunduva)".

Deste modo vale ressaltar, que 0 aspecto cultural do artesanato utilitário foi perdendo espaço para os utensílios domésticos, adquiridos na cidade - é chegada a era dos plásticos. A cultura tradicional de confecção de utensílios de madeira e de fibra, vai perdendo sua importância no grupo. De certa forma, 0 artesanato de fibra de bananeira veio contribuir para resgatar e valorizar a expressão artesanal desse povo.

\subsection{A questão ambiental e 0 artesanato}

\subsubsection{0 modo de vida das comunidades e as restrições ambientais}

As comunidades quilombolas da região do Vale do Ribeira, dentre elas as de Ivaporunduva, André Lopes e Sapatu, sofreram mudanças diretas no que diz respeito a sua economia de subsistência devido ao processo de criação das Unidades de Conservação (UC) no Vale do Ribeira. Os integrantes dessas comunidades viviam basicamente do extrativismo e da agricultura de coivara (agricultura que implica na derrubada e queima da mata, cultivo da área por até três anos e pousio) e tinham essa possibilidade de mobilidade agrícola. Segundo a irmã Sueli, 
como conseqüência das imposições da legislação ambiental houve o aumento da exploração do palmito na região:

"(...) A exploração clandestina do palmito era realizada em situações muito precárias. Causou empobrecimento cultural nas comunidades, pois a venda do palmito que no começo, pareceu um complemento da renda, acabou se tornando a atividade principal e clandestina. Eles cortavam e também processavam o palmito no meio do mato, sem muitas condições de higiene, gerou uma série de problemas" (irmã Sueli).

No Estado de São Paulo a leis ambientais começaram a ser aplicadas como mais rigorosidade a partir dos anos 80 , e com isso várias das comunidades do Vale passaram a ter dificuldades ou impedimentos para exercerem algumas das suas atividades agrícolas tradicionais. Em conseqüência, o extrativismo discriminado de algumas espécies nativas passou a ser uma atividade rotineira.

Na década de 80, em quase todos os municípios do Vale, ocorreram conflitos por causa de questões fundiárias tanto ligadas a posseiros e à especulação imobiliária como à implantação das UC. A imposição de leis ambientais não consideraram em muitos casos, a existência das comunidades tradicionais ali presentes. Relata Sueli, da Paróquia de Eldorado:

"Teve uma série de conflitos fundiários generalizados no Vale. Ocorreu em Itariri, Eldorado, Miracatu, Iporanga, parecia que era pontual, mas era meio geral. A questão do meio ambiente, as leis restritivas que não consideram aquelas comunidades que estão ali há 400 anos e que preservaram a floresta e então a partir disso as comunidades quilombolas do Vale começaram a sofrer restrições pelas atividades que praticavam na terra. Hoje, o pessoal das instituições ambientais do Governo começam a perceber mais que os verdadeiros guardas são os membros das comunidades tradicionais" (irmã Sueli).

Depois da criação do Parque Estadual de Jacupiranga, que faz limite com as comunidades de Sapatu e André Lopes, e o Parque Estadual de Intervales, vizinho de Ivaporunduva, a prática de coivara se tornou cada vez mais difícil para ser realizada, ocorrendo a diminuição da produção agrícola de subsistência nas comunidades. Configura-se assim a 
necessidade de tais comunidades terem alternativa de renda, pois como já não podiam cultivar da forma tradicional, necessitavam mais diretamente de dinheiro para que pudessem obter 0 mínimo para sobreviverem. $\mathrm{O}$ artesanato de fibra de bananeira é hoje visto como uma atividade alternativa de complemento de renda para as pessoas que têm afinidade com este tipo de trabalho e a oportunidade para comercializar sua produção. Além disso, há outro fator importante, o fato de que para obtenção da matéria prima (o pseudocaule da bananeira) para produção do artesanato com fibra de bananeira não há necessidade do aval de nenhum órgão ambiental, pois não se trata de uma espécie nativa da Mata Atlântica, e sim de uma espécie exótica agrícola.

Hoje são observadas áreas pequenas de roça de subsistência, ao contrário de antigamente, quando as roças segundo relato de membros das comunidades pesquisadas, eram de até doze alqueires e faziam-se mutirões para plantio e colheita das roças.

"(...) as roças acabaram, o mato começou a crescer e o palmito acabando, acabando...Aí o pessoal começou a fazer alternativas, uns faziam doces para vender...com a enchente também acabou o serviço, os fazendeiros que davam serviços (limpar 0 bananal, roçar pasto) pararam de dar". (Sr. Ditão)

Em conseqüência de todo esse processo de mudança, para as comunidades quilombolas restaram poucas alternativas econômicas rentáveis. Hoje em dia, as comunidades quilombolas têm que pedir autorização ao Departamento Estadual de Recursos Naturais (DEPRN) ${ }^{20}$ para realizarem qualquer tipo de prática agrícola que necessite realizar a supressão de vegetação.

Embora não seja proibido o manejo agrícola nos territórios dessas comunidades, faz-se necessário que o ITESP cumpra determinados procedimentos para que as famílias que queiram fazer os seus plantios de subsistência obtenham a licença ambiental junto ao DEPRN.

Torna-se relevante dizer que mesmo com a criação das UC no Vale, em específico na região de Eldorado, e com algumas mudanças que elas provocaram em relação à forma de agricultura praticada nos quilombos, esta ainda hoje é baseada no "saber-fazer", que exige um profundo conhecimento sobre os recursos naturais locais, seus limites e potencialidades.

\footnotetext{
20 No Estado de São Paulo, as atividades de licenciamento ambiental que envolvem uso e supressão da vegetação nativa é de responsabilidade do Departamento Estadual de Recursos Naturais (DEPRN)- Secretaria do Meio Ambiente do Estado de São Paulo.
} 
Sabe-se também que a problemática ambiental não é ideologicamente neutra nem é alheia a interesses econômicos e sociais. Esta se originou do processo histórico do domínio do sistema de produção capitalista, onde a tecnologia está a serviço da maximização dos lucros e os excedentes econômicos em curto prazo (Leff, 2002).

Observa-se ainda nos dias atuais que o envolvimento das comunidades locais no Vale do Ribeira é incipiente com relação às decisões da política regional. As comunidades locais historicamente foram entrando no processo de subutilização de suas potencialidades, tanto no que se relaciona aos recursos naturais locais como em relação ao conhecimento que tais grupos humanos possuem e as estratégias que utilizam para o uso dos mesmos, de acordo com a realidade ecológica local em que vivem.

Pela ausência de envolvimento das comunidades locais nos projetos de desenvolvimento propostos por instituições governamentais para o Vale, muitos deles fracassaram em virtude da sua insustentabilidade (Carril,1995). Exemplos relacionados diretamente às comunidades quilombolas estudadas, são alguns projetos de geração de renda introduzidos pelo ITESP, como o de criação de capivara em Sapatu, o de criação de galinha nos terreiros dessas comunidades e a produção de mudas de palmito implantada pela FF em Ivaporunduva, com o objetivo de repovoamento de espécie na área quilombola e a venda de mudas.

Talvez isso ainda ocorra nos projetos implantados no Vale, devido à ausência de percepção dos planejadores quanto a um fator de extrema relevância que é a forma de organização agrícola autóctone dessa região, o modelo de"cultura rústica", no qual os núcleos familiares são as unidades de produção e de consumo, em que as relações de ajuda são baseadas nos laços de parentesco.

A questão ambiental é vista neste trabalho como situação sine qua non para 0 alcance da construção de formas alternativas de desenvolvimento, ou ecodesenvolvimento.

\subsubsection{A bananicultura}

Nas comunidades de Ivaporunduva, André Lopes e Sapatu, o cultivo de banana sempre esteve presente nos quintais e nas áreas de roça cujo produto de interesse é a banana in natura, para venda. Esta fruta, além de fazer parte da dieta alimentar dos indivíduos, é também 
comercializada no mercado regional. Atualmente a produção de banana é a atividade econômica principal dessas comunidades e algumas famílias também produzem doce de banana para venda no mercado de Eldorado. As áreas de cultivo nas comunidades estudadas são locais de encosta de morro e na beirada do rio Ribeira, que são mantidos ainda no esquema familiar.

De acordo com o relato do Sr. Wagner, técnico da Fundação Florestal do escritório de Registro, que há muitos anos trabalha no Vale, na década de 90, a agricultura familiar exercida nos quilombos não estava baseada na bananicultura, mas na agricultura de subsistência, sendo esta a atividade econômica principal.

Fazendo uma análise ambiental da atividade, observa-se que as comunidades envolvidas nesta pesquisa não consideram a bananicultura como impactante em termos ambientais. Sr. Ditão, uma das lideranças de Ivaporunduva, relata que nos bananais das comunidades sempre estão presentes algumas pragas, como o moleque da bananeira, mas que isso nunca chegou a ser muito expressivo de forma a tornar o uso de produtos químicos nos bananais uma ação constante."Hoje, em Ivaporunduva, tem muitos produtores de banana certificados e cada vez menos estamos usando produtos químicos", afirma Sr. Ditão. O mesmo pode ser percebido com relação à questão dos resíduos oriundos dessa atividade, ou seja, este subproduto também nunca foi encarado pelos agricultores quilombolas como causador de impacto ambiental.

"Para nós a banana não tinha valor naquele tempo que não tinha empecilho para se fazer a agricultura tradicional, não tinha a estrada dentro de Ivaporunduva, a gente ia para outro lado do rio...só vendia para doce na época da temporada...aí mais tarde chegou o artesanato de fibra de banana, o curso como alternativa. Hoje as coisas aqui na comunidade estão melhores...tanto que tem gente que tinha saído daqui para trabalhar na cidade há muito tempo e está voltando aqui pelo menos dá pra trabalhar umas coisas (roça, banana...) e ir tocando. A coisa lá fora está muito difícil, muita violência também" (Sr. Ditão).

Os próprios agricultores sempre fizeram um manejo deste resíduo. Depois que retiram 0 cacho de banana, cortam o tronco da bananeira a uma distância aproximada de um metro e meio do chão, deixam escorrer a água do tronco, que segundo eles, serve de alimento para as plantas de bananeiras filhotes e depois de alguns dias picam o restante deste material e 0 incorporam ao solo para na adubação das novas bananeiras. 
Observa-se na Tabela 5, a porcentagem de área usada para a agricultura de subsistência. No mapa II: Ivaporunduva, André Lopes e Sapatu, Distribuição do Uso da Terra (em anexo), na área de terra ocupada pelas comunidades estudadas, pode-se verificar que mais de 90\% da vegetação florestal existente encontra-se conservada. Dados representados no referido mapa conferem que as áreas ocupadas por bananais nas referidas comunidades são de pequena extensão, comparadas ao tamanho das áreas ocupadas pela Floresta Ombrófila existente nesses territórios.

Tabela 5. Dados relativos ao uso da terra nas comunidades no ano de 2002

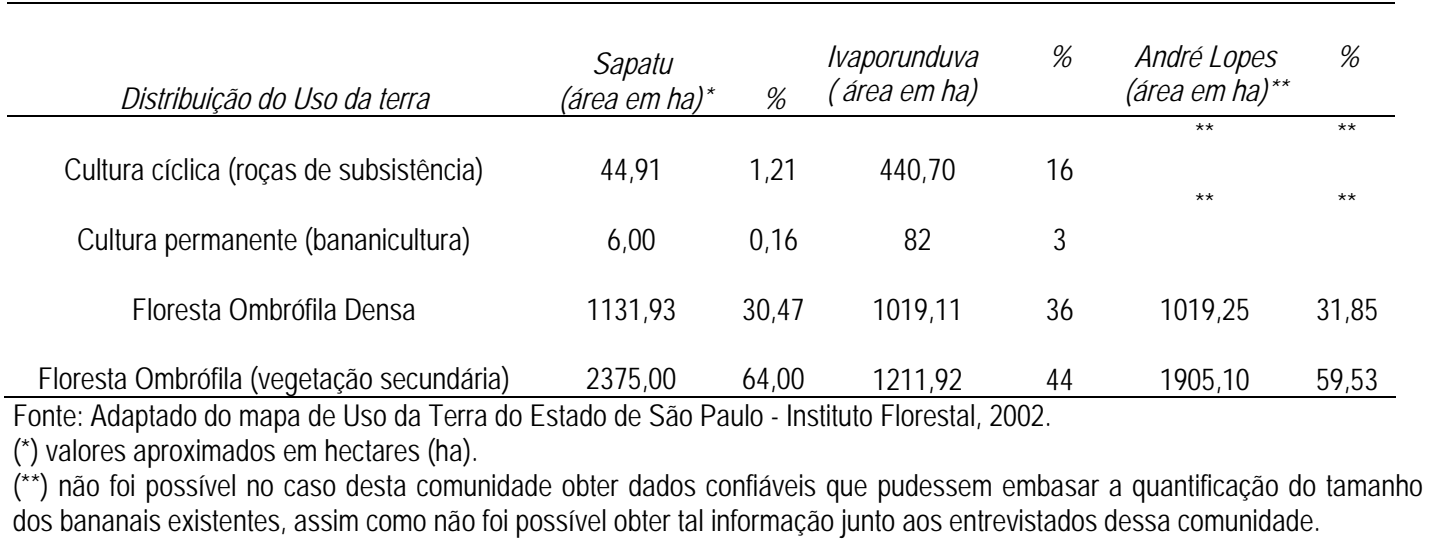

Em entrevista com o Sr. Ditão, foi obtido em meados de 2004, aproximadamente 18\% da área total da comunidade de Ivaporunduva estava sendo utilizada para agricultura e que deste total 7 a $8 \%$ eram ocupadas por bananais.

Tanto este relato como os dados da Tabela 5, dão embasamento para que se afirme que os quilombolas de Ivaporunduva, mesmo praticando a bananicultura, têm conservado a Mata Atlântica existente em seu território. Essa observação vale também para a comunidade de Sapatu, ou seja, a bananicultura não pode, no atual momento, ser considerada como impactante ambientalmente.

Nas comunidades estudadas, os bananais são cultivados na beira do rio e no sertão (Figura 24), ou seja, em locais no interior da mata, e espalhados, o que impossibilita quantificar com precisão a extensão dos bananais das comunidades. Um agricultor de Sapatu, o Sr. João de 
Lima, relatou que um agricultor pode ter várias áreas de bananeiras, como é o caso dele, que possuiu, no total, por volta de 2000 pés plantados. Ele cita exemplos de outros produtores:

"Pedro, Joel, Juvenal, Reinaldo, o compadre Joaquim e o Tiago têm aproximadamente 2 mil pés de banana cada um" (Sr. João de Lima, agricultor de Sapatu).

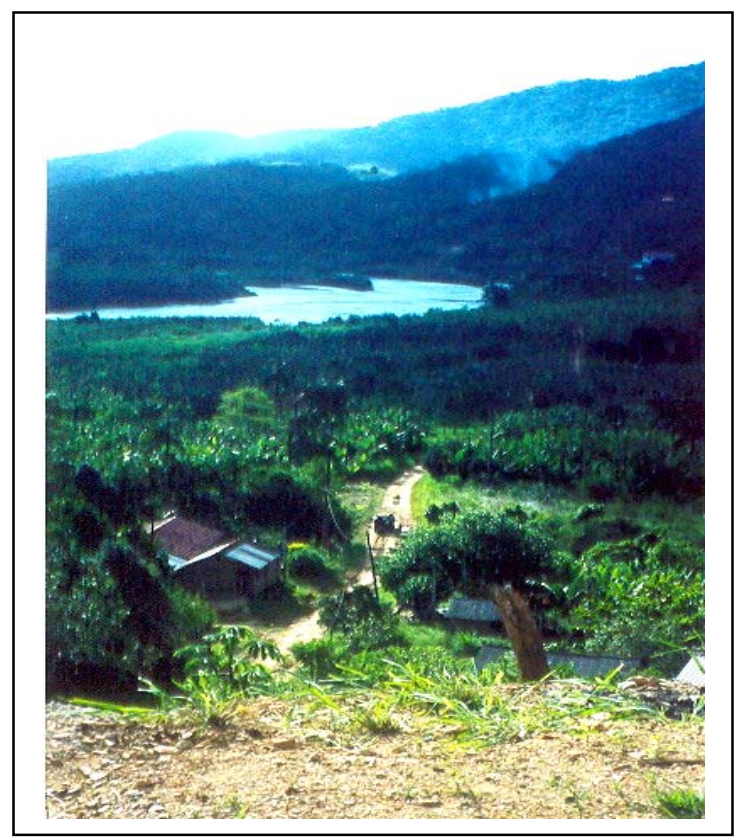

Figura 24. Vista de uma área de bananal na comunidade de Ivaporunduva a beira do rio Ribeira

Com base neste depoimento, calcula-se que na comunidade de Sapatu existem em média 12 mil pés de bananeira. Já na comunidade de André Lopes não se obteve dados suficientes que possibilitassem dimensionar o tamanho da área de bananal na comunidade. 0 mapa II: Ivaporunduva, André Lopes e Sapatu, Distribuição do Uso da Terra, não permite possível a visualização dessas áreas.Tal fato pode ser explicado se for considerado que o quadro geográfico desta comunidade difere do das outras duas, porque ela teve boa parte de seu território incorporado ao Parque Estadual de Jacupiranga, quando este foi criado. Por esse motivo, muitos dos moradores desta comunidade vivem de outras atividades econômicas, que não a produção de banana. Algumas pessoas trabalham como prestadores de serviços para a Prefeitura de Eldorado e outras ainda como monitores ambientais no Parque no Núcleo Caverna 
do Diabo. Assim, no mapa II, pode-se observar que em André Lopes há mais de 90\% de vegetação de Mata Atlântica presente. Tanto esta como as demais comunidades estudadas praticam as mesmas estratégias para o uso e conservação dos recursos existentes em seus territórios.

Segundo relatos de entrevistados, no ano de 2004, alguns agricultores aumentaram suas áreas de bananal devido à melhoria de preço da fruta neste ano, chegando a ser vendida a caixa de banana no mercado a $\mathrm{R} \$ 4,50$.

Fazendo uma análise ambiental com base nos preceitos do ecodesenvolvimento, podese afirmar que o sistema de produção da bananicultura que é praticado pelos quilombolas não chega a causar impacto ambiental negativo. Além de que não houve aumento das áreas de bananais em nenhuma das comunidades pesquisadas por motivo da atividade artesanal com fibra de bananeira. Isso porque esta é uma atividade completar à principal, que é a agricultura de subsistência e a bananicultura. Pode-se afirmar portanto, que a atividade do artesanato com a fibra de bananeira não causa impacto ambiental, já que são utilizados os resíduos desta cultura, ainda que em pequena escala.

\subsubsection{Os resíduos da bananicultura na atividade artesanal}

A partir dos cursos de capacitação para produção do artesanato de bananeira, foi aberto um campo para reorganização dos ciclos de uso dos resíduos da bananicultura nessas comunidades. O resíduo material deixou de ser um resíduo ou perda para se tornar recurso potencial a ser explorado pelas comunidades quilombolas de Ivaporunduva, André Lopes e Sapatu. Segundo relatos, calcula-se que de modo geral, os bananais das famílias das artesãs entrevistadas tenham entre 3 a 5 mil pés, o que equivale a uma média de 160 toneladas de pseudocaule (matéria-verde) em 2,5 ha de bananeira.

Estima-se que se um pseudocaule é constituído de aproximadamente $92 \%$ de água e $3 \%$ de fibra ${ }^{21}$, um pseudocaule com peso médio de $40 \mathrm{~kg}$ de matéria verde fornecerá em média 1,2 $\mathrm{kg}$ de matéria seca (fibra). Portanto, após a colheita da fruta, em um hectare de bananeira, com

\footnotetext{
${ }^{21}$ Hiroce, R. O aproveitamento do pseudo-caule. O Estado de São Paulo, SP -19/03/1972. Suplemeto Agrícola nº877:p.11.
} 
2.000 plantas (espaçamento $2 \times 2 \mathrm{~m}$ ), serão gerados cerca de 80ton/ha de matéria verde e 2,400 $\mathrm{kg} /$ ha ou 0,0024 ton/ ha de matéria seca (fibra).

Em Ivaporunduva, atualmente, há em média 77.122 pés de banana, isto significa dizer que existem aproximadamente $93.000 \mathrm{~kg}$ ou 0,093 ton/ ha de resíduos provenientes desta cultura. Já no caso de Sapatu, estima-se que existam aproximadamente 12.000 pés de bananeiras, isso significa uma média $14.400 \mathrm{~kg}$ ou 0,014 ton/ ha de matéria seca oriunda de todos pseudocaules existentes na comunidade.

As artesãs da comunidade de Sapatu e de Ivaporunduva afirmam que ultimamente têm utilizado em média 3 troncos (pseudocaule)/ mês para confecção de peças artesanais, ou seja, 3,6 kg matéria - seca/mês/artesã. Segundo relatou Paulo e Caca, entrevistados de Ivaporunduva; os artesãos de Ivaporunduva não utilizam grande quantidade de troncos de bananeira porque não fazem muito artesanato, pois o comércio para 0 artesanato ainda é pequeno, tem pouca demanda.

A colheita da produção de banana em Ivaporunduva é realizada duas vezes por semana, o que significa que há uma grande disponibilidade de matéria prima para o artesanato. De acordo com informações a respeito da bananicultura, nesta comunidade atualmente, estima-se que haja uma produção de fruta que eqüivale a 9.382 pseudocaule cortados/mês, isto significa uma média 0,011 ton/ mês de matéria seca, ou seja, 11,000 kg/ mês de resíduo disponível para ser utilizado na produção artesanal com fibra de bananeira. Diante desta observação, vale dizer que mesmo se a demanda pelo artesanato de fibra de bananeira aumentasse expressivamente 0 uso do resíduo dos bananais, ainda assim, restaria muito material disponível nos bananais em forma de resíduos.

Nesse momento é importante analisar o uso dos resíduos da bananicultura no artesanato numa perspectiva do ecodesenvolvimneto, ou seja, avaliar se e até que ponto a atividade artesanal com uso desse resíduo encontra-se em concordância com os preceitos por ele defendido. Vale destacar, dentre estes, a inclusão do aproveitamento de resíduos tanto produzidos nas cidades, como os produzidos nas zonas rurais, de modo que estes sejam 
potencializados como recursos e viabilizados de maneira que contribuam para trazer melhorias na "qualidade de vida22" das pessoas.

A fim de melhor explicar o manejo realizado pelos artesãos das comunidades estudadas para obtenção dos troncos de bananeira, vale descrever tal processo: este inicia-se com o corte e retirada dos pseudocaules do bananal, sendo este comumente do próprio artesão, ou seja, é um material cuja obtenção não envolve custos diretos. Procede-se em seguida à separação das bainhas foliares (estrutura vegetal que compõe o pseudocaule). Quando há uma quantidade grande de encomendas de peças artesanais, o grupo realiza a operação de corte dos troncos em esquema de mutirão. Quando o tronco não é muito grande ou se tem uma pessoa para ajudar no momento de retirar o tronco, este é trazido inteiro até a casa, quando não se tem ajuda, a separação das bainhas é feita no próprio bananal. As bainhas selecionadas são trazidas para 0 local de trabalho e o restante do resíduo é abanado no próprio bananal. Depois da seleção das bainhas, elas são cortadas longitudinalmente em tiras de aproximadamente $3 \mathrm{~cm}$ e dispostas em varais das casas dos artesãos para secarem ao sol. Quando estão suficientemente secas e prontas para serem trabalhadas nos teares, ou seja, para serem tecidas, são retiradas e armazenadas em sacos plásticos, caixas de papelão ou mesmo dependuradas em algum local da casa onde possam ficar protegidas da chuva e do sol.

O potencial ambiental de uma região não está determinado tão somente por sua estrutura ecossistêmica, mas pelos processos produtivos que nela se desenvolvem, permitindo diferentes formações sócio-econômicas (Leff, 2002). Desse modo, pode ser dito que as estratégias sócio-ambientais e econômicas pregadas pelo ecodesenvolvimento são formas de estimular a reflexão e a valorização do potencial dos recursos ambientais aplicadas à região do Vale do Ribeira, sendo esta, uma região que apresenta grandes peculiaridades tanto do aspecto ambiental como humano, torna-se necessário desenvolver novas práticas de produção condizentes com as relações de sociedade e meio ambiente que existente na região.

A atividade do artesanato com fibra de bananeira tem gerado mudanças positivas com relação à consciência ambiental e à utilização dos recursos disponíveis, na medida em que o

\footnotetext{
22 Segundo Cebotarev (1982, p.149), essencialmente, o conceito de qualidade de vida em sua preocupação com o bem estar do homem é profundamente humano e tem o potencial de apontar novos rumos para os programas de desenvolvimento rural em particular. Embora não se tenha um conceito único de qualidade de vida, em razão de sua complexidade e abrangência, é evidente a sua importância como subsídio para formulação de políticas públicas e planejamento (Khan, 2001, p.149).
} 
aproveitamento dos resíduos da bananicultura ajudaram a fortalecer o elo das comunidades com o meio ambiente local.

\subsection{A organização dos artesãos}

$\mathrm{Na}$ organização da atividade artesanal, nas comunidades estudadas o ITESP teve um papel chave. Tal fato se deveu à contratação, no ano de 2000 de um engenheiro agrônomo, 0 senhor Márcio Halla, para trabalhar exclusivamente com esta atividade nos quilombos em Eldorado e Iporanga, conforme anteriormente detalhado. Com o auxílio técnico deste profissional, os artesãos criaram em meados de 2000 o grupo "Raízes da Cultura Quilombola", que envolvia representantes das comunidades de Sapatu, André Lopes, Ivaporunduva, Nhunguara, Pedro Cubas, São Pedro, Galvão, Maria Rosa e Pilões.

Esse técnico auxiliou a mobilização dos artesãos para a organização do grupo, a partir de reuniões quinzenais em André Lopez, devido à localização dessa comunidade facilitar a logística do pessoal que vinha de Sapatu e de São Pedro. Mais tarde, ele percebeu que a grande quantidade de pessoas dentro do grupo estava prejudicando o processo de organização da atividade artesanal. Houve, então, a motivação para que cada comunidade participante do grupo escolhesse dois representantes para participarem das reuniões do grupo. Dessas reuniões, saiu a decisão de se criar uma marca para o grupo, ou seja, uma etiqueta para compor as peças artesanais produzidas pelos artesãos.

No ano de 2001, houve uma desarticulação no grupo Raízes, com a saída dos artesãos da comunidade de Ivaporunduva. Isso ocorreu porque os artesãos de André Lopes começaram a expôr suas peças na beira da estrada que dá acesso à Caverna do Diabo, passagem obrigatória dos turistas que vão para a Caverna. De outro lado, o pessoal de Ivaporunduva, que já recebia visitas escolares na comunidade, passou a vender 0 artesanato na própria comunidade. Algumas pessoas do grupo Raízes reclamaram que Ivaporunduva estava passando por cima dos outros. Ivaporunduva então, passou a trabalhar a atividade do artesanato com fibra de bananeira de forma centralizada na comunidade. O técnico do ITESP, o Sr. Márcio Halla, retratada em seu depoimento as mudanças provocadas pela saída dos artesãos de Ivaporunduva do grupo Raízes. 
No ano seguinte, integrantes da comunidade de Morro Seco, situada no município de Iguape, ingressaram no grupo. Mais tarde, em Morro Seco formou-se um grupo de artesanato próprio.

"Ivaporunduva se fortaleceu e o grupo Raízes enfraqueceu, porque para Ivaporunduva sempre tudo é mais fácil, eles têm acesso a muito mais informação, aos canais, o turismo também é um fator importante. As lideranças mais expressivas são de Ivaporunduva, é uma comunidade que está num patamar acima das outras... têm mais oportunidades...eles têm projetos acontecendo, o ISA, a Unicamp" (Márcio Halla)

Vale dizer que o artesanato com fibra de bananeira, nessa ocasião, já estava sendo visto como uma alternativa de geração de renda e que aliado ao turismo da região, seria uma atividade interessante e promissora para essas comunidades.

A partir de meados de 2001, o referido técnico do ITESP que lidava com 0 tema artesanato foi substituído por uma nova técnica, na regional de Eldorado. Ela passa então a auxiliar as comunidades quilombolas de Eldorado no que está relacionado à atividade artesanal (logística, informação a respeito de feiras e outros eventos ligados à atividade artesanal). Ela também tem propiciado a articulação com o SEBRAE de Registro para cursos e possibilidades de comercialização dos produtos de fibra de bananeira, aquisição de teares e cursos de capacitação.

Outras comunidades quilombolas do Vale também demonstraram interesse pelo curso de artesanato com fibra de bananeira. Em função dessa demanda, em maio de 2002, o ITESP duas artesãs da comunidade de André Lopes e duas de Sapatu, com a finalidade de atuarem como agentes multiplicadores, ensinar a pessoas de outras comunidades as técnicas do artesanato com fibra de bananeira. Foram contempladas as comunidades de Nhunguara, Pedro Cubas, São Pedro, Galvão, no município de Eldorado e a comunidade de Morro Seco, no município de Iguape.

Todo este cenário relatado despertou em algumas comunidades a necessidade de se buscar "estratégias" para melhorar a organização da atividade do artesanato com fibra de bananeira. O grupo de artesanato de Ivaporunduva, após se desvincular do grupo Raízes, buscou estratégias de organização, através de reuniões mensais, da escolha de um coordenador do grupo e da criação de um fundo de reserva financeira para as artesãs. No final de 2002, foi aberto um livro ata para registro das decisões e organização do grupo. Como há na Associação 
da comunidade tal procedimento formal de organização administrativa, o grupo do artesanato resolveu adotar o mesmo procedimento. Em conversas com os entrevistados de Ivaporunduva, ficou evidenciado que o grupo de artesanato tem preocupação com a organização visando obter melhorias na produção e na comercialização do artesanato com fibra de bananeira.

Observa-se que na comunidade de Ivaporunduva há um espírito de organização interna e auto-valorização bastante expressivo em seus membros. Percebe-se que estes se sentem fortes enquanto comunidade organizada internamente e politicamente bem articulada no que diz respeito à escolha de"parceiros" tanto governamentais como não governamentais, ou seja, no que se refere à rede social e política das relações da comunidade com outros colaboradores, como é nítido neste depoimento:

"(...) acho que de uma certa forma nos afastamos das políticas de outras comunidades, e de certa forma nos destacamos... Despertou o interesse de outras entidades em serem nossos parceiros. Hoje tem muitas instituições que querem trabalhar com a comunidade, mas não estão nem aí para os resultados, nós queremos resultados concretos para a comunidade" (Paulo, coordenador do grupo de artesanato de Ivaporunduva).

Tal consciência poderia ser atribuída ao fato de Ivaporunduva ser a primeira comunidade negra a ser reconhecida no Estado de São Paulo como quilombola, tendo sido sua organização e articulação política desenvolvida há mais tempo, se comparada com as demais existentes no Vale. Também por influência do trabalho desenvolvido pela Pastoral da Terra nesta região, alguns membros de Ivaporunduva já participavam do movimento negro nacional e estavam envolvidos com a temática social do reconhecimento e valorização das comunidades negras. Esse processo, com a Constituição de 88, avançou e ganhou relevância no quadro político social do país.

De modo geral, os resultados têm sido positivos: os trabalhos estão sendo comercializados em feiras e exposições regionais e em outros locais do Estado de São Paulo. Não só Ivaporunduva tem estruturado a atividade artesanal de bananeira, pode-se verificar que no interior de cada uma das comunidades há uma dinâmica própria, com forma própria de organização, de articulação entre artesãos, de distribuições de funções. Foi observado que todas 
essas etapas são percorridas segundo a vontade dos artesãos, espontaneamente, conforme as afinidades individuais. Isso fica explícito nas falas de Paulo, de Ivaporunduva, e de Sônia, artesã de Sapatu:

"(...) quem quiser do grupo pode trabalhar à vontade, tem gente que gosta mais de trabalhar vendendo..." (Paulo - Ivaporunudva)

"(...) não consigo fazer um planejamento. É como se 0 trabalho de artesanato fosse uma atividade para a hora de folga". (D. Sônia - Sapatu)

No ano de 2000, no mês de setembro, as comunidades quilombolas expuseram pela primeira vez seus produtos no evento cultural"Revelando São Paulo". Trata-se de uma feira de exposição cultural realizada pelo Governo do Estado de São Paulo e pela Secretaria da Cultura, com o objetivo de valorizar e mostrar a diversidade das artes do Estado de São Paulo, dando destaque ao artesanato existente nos diversos municípios, dentre eles o de Eldorado. Através das prefeituras municipais de várias cidades do Estado, representantes de diferentes comunidades urbanas e rurais vêm participando deste evento, o qual ocorre anualmente no mês de setembro, desde 1997 no Parque da Água Branca, na cidade de São Paulo.

$\mathrm{Na}$ ocasião do Revelando São Paulo de 2003, a prefeitura de Eldorado cedeu 0 transporte para os artesãos quilombolas, nos anos anteriores, esse apoio era dado pelo ITESP.

Em 2002 foram ministrados cursos pelo SEBRAE de Registro voltados à capacitação de artesãos das comunidades de Sapatu, André Lopes e Morro Seco abordando os aspectos mercadológicos da produção, como por exemplo, atribuição de preços às peças artesanais que produzem.

"Comecei em 2002 um trabalho com o Grupo Raízes da Cultura Quilombola que agrupava as cinco ou sete comunidades mais expressivas no artesanato em fibra de bananeira, depois, por questões operacionais (dificuldade para reuni-los, falta de meios de comunicação, entre outros), interrompemos as atividades, retomando em 2003 atendendo as comunidades de Morro Seco e Sapatu". (Técnica do SEBRAE de Registro). 
As artesãs de Sapatu, ao serem questionadas a respeito dos cursos proporcionados pelo SEBRAE, responderam que o critério utilizado pelo SEBRAE não é viável para a realidade de comércio com 0 artesanato de fibra de bananeira na região de Eldorado.

"...Eu procuro fazer do jeito que foi dado, mas se a gente for colocar como foi ensinado no curso, a gente não vende, então acabamos nem colocando o preço como ensinaram no curso porque não dá pra acompanhar, o tempo gasto tem que estar marcado, muitas pessoas não conseguem marcar, assim falou madrinha Esperança. Ela fez o curso também, mas não dá pra marcar tempo curto.. muitas vezes porque chega uma pessoa em casa e você tem que parar de contar, e às vezes se perde..." (D. Esperança)

No ano de 2003, o técnico do ISA, que atua diretamente na comunidade, procurou a equipe responsável pela artesanato de fibra de bananeira da ESALQ, com a finalidade de solucionar um problema de qualidade da fibra levantado pelos artesãos. O problema é relacionado a microorganismos (fungos) e insetos que produzem danos à fibra e, por conseqüência, comprometem a qualidade do artesanato de bananeira que vem sendo produzido na comunidade. Em função desta demanda, foi elaborado um Projeto de parceria entre o ISA, a ESALQ e a comunidade de Ivaporunduva, aprovado pela FAPESP em outubro de 2004, para desenvolver atividades voltadas ao fortalecimento da atividade artesanal com fibra de bananeira (melhoria da comercialização, certificação orgânica, artesanato da fibra da bananeira etc.), através de atividades de formação e capacitação de novos e dos antigos artesãos.

Em março de 2004, o SEBRAE financiou um novo curso de capacitação para trabalhar com a fibra de bananeira, direcionado às pessoas da comunidade de Sapatu, que foi ministrado por duas artesãs da própria comunidade de Sapatu: Sônia e Esperança. Estas artesãs são as que mais freqüentemente confeccionam peças com fibra de bananeira para a venda.

$\mathrm{O}$ que se percebe com relação à rede social da atividade artesanal com fibra de bananeira, é que ela se construiu a partir de uma junção de esforços dos indivíduos de instituições governamentais e não governamentais, ou seja, os colaboradores externos, que vislumbraram esta atividade como uma alternativa viável de ser mantida pelas comunidades quilombolas, já que neles haviam pessoas interessadas e que estavam produzindo e vendendo peças feitas com a fibra, ainda que pontualmente. Como exemplo, os artesãos das comunidades 
de Ivaporunduva, André Lopes e Sapatu. Para essas pessoas, 0 artesanato de fibra de bananeira é considerado como a principal atividade econômica que permite à mulher, obter algum tipo de renda dentro de casa.

Tabela 6. Os colaboradores externos envolvidos com a atividade artesanal de fibra de bananeira e os seus papéis

\begin{tabular}{|c|c|c|}
\hline $\begin{array}{l}\text { Colaboradores } \\
\text { externos envolvidos }\end{array}$ & $\begin{array}{l}\text { Período de } \\
\text { atuação }\end{array}$ & Formas de atuação dos colaboradores externos \\
\hline ISA & desde 2000 & $\begin{array}{l}\text { viabilização de curso/ fomento a organização interna do grupo/ construção de } \\
\text { uma casa na comunidade para trabalhar e vender o artesanato }\end{array}$ \\
\hline ITESP & desde 2000 & $\begin{array}{l}\text { organização dos artesãos/ logística dos artesãos para as feiras e } \\
\text { exposições/busca de parcerias que possam contribuir para melhoria da atividade } \\
\text { nas comunidades }\end{array}$ \\
\hline $\begin{array}{l}\text { Prefeitura Municipal } \\
\text { de Eldorado }\end{array}$ & 2003 e 2004 & Auxílio com transporte de artesãos para o Revelando São Paulo \\
\hline SEBRAE & 2002 a 2004 & $\begin{array}{l}\text { Cursos de capacitação voltados ao mercado e a organização da produção para } \\
\text { venda do artesanato }\end{array}$ \\
\hline FF & 1997e 1998 & Viabilização de um local para venda do artesanato na Caverna do Diabo \\
\hline SUTACO & 1997 e 1998 & $\begin{array}{l}\text { Viabilização financeira de curso e doação de teares em André Lopes e } \\
\text { Ivaporunduva }\end{array}$ \\
\hline SUTACO & em 2000 & Viabilização de curso a outras comunidades quilombolas do Vale \\
\hline Mitra Diocesana & 1998 e 2002 & Aquisição de teares \\
\hline F. Palmares & 1998 e 2004 & $\begin{array}{l}\text { Contribuição na viabilização dos primeiros cursos e viabilização financeira de } \\
\text { intercâmbio com outras comunidades para repasse das técnicas }\end{array}$ \\
\hline
\end{tabular}

Essa rede foi constituída espontaneamente, isto é, os colaboradores primários, à medida que foram acreditando na possibilidade de se trabalhar com a fibra de bananeira, organizaram-se e despertaram a atenção de colaboradores externos para o artesanato de fibra de bananeira. Os artesãos, gradativamente, obtiveram auxílio para suprir as demandas que foram surgindo, à medida que a atividade foi sendo sedimentada, como foi o caso das construções de infraestrutura nas três comunidades destinadas à atividade e à obtenção de recursos financeiros para aquisição de mais teares e outros ganhos com o objetivo de fortalecer a atividade. 


\subsubsection{A relação de gênero e os espaços da confecção artesanal}

Com o fomento ao "artesanato", foi agregado valor aos trabalhos artesanais, já praticados por algumas pessoas das comunidades quilombolas estudadas nesta pesquisa. Podese dizer que de algum modo, a atividade artesanal com fibra de bananeira contribuiu no sentido da valorização pessoal e melhoria da auto-estima dos indivíduos que a adotaram.

$\mathrm{O}$ artesanato com fibra de bananeira conferiu uma identidade, às mulheres e jovens, que passaram a ser vistos como profissionais.

Para os jovens, a atividade é uma possibilidade de se obter recurso financeiro dentro da própria comunidade, não precisando buscar trabalho fora, não estimulando o êxodo rural. Nota-se que tal fato não é claro para os envolvidos, mas ao se observar jovens, homens e mulheres envolvidos com a atividade, tanto na produção como na venda, nos eventos, torna-se claro que esta é, de fato, uma possibilidade de valorizar os jovens perante o seu grupo e à sociedade de fora da comunidade. Como exemplifica Paulo em seu depoimento a seguir:

\footnotetext{
"(...) Os jovens de Ivaporunduva que às vezes querem fazer alguma coisa, pois já brincaram, já estudaram, daí fazem pulseiras, uma peça ou outra ... Bem legal isso! porque eles vendem e não estão precisando pedir dinheiro para o pai". (Paulo- Ivaporunduva)
}

Algumas artesãs manifestaram a vontade de trabalharem na produção artesanal em grupo, para o nivelamento da qualidade dos produtos, e também como uma estratégia para não serem absorvidas pelas atividades domésticas sobrando pouco tempo para fazer 0 artesanato. Esta foi uma estratégia defendida por alguns técnicos das instituições que atuam junto aos artesãos, o que fomentou a construção de um espaço físico nas comunidades destinado a prática artesanal.

Hoje, a construção feita em André Lopes está sendo utilizada como escola da comunidade, já que a idéia original não vingou. E a de Sapatu está desativada.

"(...) a organização em termos coletivos é complicada... talvez porque essa história de fazer artesanato para venda seja uma atividade nova no contexto das comunidades". (Sandra - Técnica da FF/ São Paulo) 
Fica expressivo no relato de uma artesã, quando indagada a respeito da produção de artesanato, em grupo, que há momentos em que o trabalho em grupo impossibilita exercerem suas funções rotineiras, mas por outro lado tem vantagens no aspecto da melhoria da qualidade das peças produzidas.

"(...) Acho bom trabalhar junto porque as peças ficam padronizadas. Aqueles que têm mais experiência podem até estar passando para as outras, assim essa parte para trabalhar em grupo é boa. Já em casa, qualquer hora de folga a gente tá trabalhando" (D. Esperança, Sapatu).

Algumas artesãs relataram que trabalhar em grupo requer mais tempo disponível, mais para estarem reunidas, depende da disponibilidade de todas. Às vezes, para quem mora mais distante é complicado sair de casa, deixar filhos, netos e marido por um dia todo. Foi observado que o tempo destinado ao artesanato é relativamente pouco em relação a outras atividades. As artesãs trabalham na atividade artesanal nos momentos entre o tempo dos afazeres domésticos diários e conforme a necessidade de plantio e colheita nas roças de subsistência. Também há artesãs que fazem parte da organização da Pastoral da Criança e têm outras atividades voluntárias com as quais também estão envolvidas. Entretanto, foi observado que na comunidade de Ivaporunduva, a produção é feita individualmente, ou seja, cada artesão produz sua peça e somente na hora de vender, todos se reúnem na Casa do Artesanato. Dona Araci, artesã desta comunidade, diz que por este motivo, cada peça fica de um jeito e o preço de venda também se torna diferente.

Com relação à confecção das peças artesanais ficou nítida há diferença entre as peças feitas mesmo sendo na mesma comunidade. Não havendo padronização no tamanho das peças, no acabamento ou no preço que são vendidas.

As artesãs reconhecem que 0 trabalho artesanal fosse realizado em grupo haveriam ganhos, como a padronização das peças, mas mesmo assim, produzem de forma individualizada por causa das tarefas que têm a cumprir diariamente como dona de casa, mãe e esposa.

Foi observado nas três comunidades que a atividade artesanal com fibra de bananeira é realizada de forma individual e por mulheres. Apenas em Ivaporunduva há dois homens que 
trabalham na atividade, mas esporadicamente. Em André Lopes o único homem que ainda está envolvido com esta atividade, não confecciona artesanato e sim faz a extração da palha para vender. E na comunidade de Sapatu não há homens com ela envolvidos diretamente. Nos depoimentos das artesãs aparece, em momentos esporádicos, que seus esposos ajudam na hora de buscar o tronco da bananeira no bananal.

A atividade do artesanato com fibra de bananeira se encaixou à prática cotidiana do trabalho doméstico, sem causar alterações negativas na rotina das donas de casa. Vale dizer que a forma como tal atividade é praticada não segue o modelo capitalista de produção.

As mulheres que aderiram ao trabalho com 0 artesanato de bananeira, adequaram a sua realização desta atividade ao tempo que dispunham entre seus afazeres domésticos. Observou-se nas casas das artesãs entrevistadas que o local destinado ao tear é a sala. Pode-se dizer que localizar o tear no "centro" da casa é uma estratégia das mulheres para orquestrar a atividade do artesanato aos demais movimentos da casa (filhos, marido, vizinhos, etc).

Nas três comunidades, foi observado que o papel dos homens perante 0 grupo está voltado às atividades sociais que requerem "exposição", como ações de"articulação política" interna e também externa à comunidade, como por exemplo, no caso da MOAB. Assim como nas atividades de mobilização desse movimento, pela participação em reuniões com representantes do governo e de outras instituições.

Nota-se que na comunidade de Ivaporunduva, os homens assumiram a organização do grupo de artesanato e também é um homem, o artesão considerado pelo grupo como multiplicador. Nos eventos em que o grupo do artesanato participa, como no caso do Revelando São Paulo, é um homem que vai como representante. Para as mulheres, é sempre mais complicado se ausentarem da casa por vários dias, mas quando a feira é na região, às vezes, vão mulheres representantes. Assim, vale ressaltar a manutenção de valores da cultura brasileira, como os referenciados por Da Matta (1985), em sua obra A Casa e a Rua, relativos à questão de gênero. As mulheres têm papel fundamental no processo organizacional do artesanato com fibra de bananeira em suas comunidades, assim como na continuidade desta até os dias de hoje.

Pode-se inferir que atividade do artesanato de bananeira tem finalidade tanto social, que é o da valorização da mulher através da realização de um trabalho extra doméstico, como de 
geração de renda. As peças confeccionadas com fibra de bananeira são consideradas como um produto artístico de valor econômico produzido pelas as mãos dos artesãos. Pode-se dizer também, que tal atividade também proporcionou a abertura de um caminho de reconhecimento e de legitimação do papel da mulher nas comunidades, como indivíduo hábil, para contribuir com a geração de renda familiar, sem comprometer seus hábitos culturais com relação a execução de suas obrigações domésticas e familiares.

A irmã Sueli faz uma análise voltada à discussão a respeito da relação de gênero, que mostra a tendência de mudança. Para ela, o comércio sempre foi a preocupação dos homens e as mulheres demonstravam maior preocupação com a panela, ou seja, com a manutenção da família. Segundo ela, hoje é diferente, a mulher tem participado mais de trabalho relacionado a questões sociais que ocorrem fora das comunidades, ou seja, a mulher está atuante no cenário que antes pertencia apenas aos homens. A irmã Sueli deixa evidente em seu relato o papel das mulheres dentro das comunidades como atores determinantes para conquistar melhores condições de vida nos quilombos.

"(...) a água em Ivaporunduva foi assumida pelas mulheres. Pergunta lá quem foi que fez a vala para colocar os canos e trazer a água até lá, foram as mulheres. A luta pelo ônibus da escola, a luta para ter um funcionário da prefeitura ali na travessia do rio com canoa..." $\mathrm{E}$ finaliza a conversa com a seguinte afirmativa:"quem vai para fora da comunidade são os homens, mas dentro das comunidade as decisões passam pelas mulheres" (irmã Sueli).

Vale ressaltar que na comunidade de Ivaporunduva, a presença masculina inicial, nos cursos ministrados, foi de quase cem por cento. Participaram apenas duas mulheres, D. Araci e D. Zilda. Estas, desde o período em que os cursos foram ministrados até os dias atuais, permaneceram fazendo o artesanato com fibra de bananeira. Apenas um dos homens que participaram dos cursos deu continuidade ao trabalho artesanal com a fibra de bananeira e é hoje considerado pelo grupo como artesão multiplicador, dando curso de repasse da técnica do artesanato com fibra de bananeira em sua própria comunidade, como para pessoas externas. No depoimento de Ditão fica claro o motivo pelo qual os homens não permaneceram envolvidos com tal atividade. 
"(...) os homens, quando viram 0 artesanato da banana acharam que poderia ser uma oportunidade de lucro imediato, rápido...mas depois que viram que não, desanimaram e foram para outras atividades (....) Então, as mulheres assumiram, porque dá para fazer em casa e dá um dinheirinho que antes elas não tinham outra atividade que revertesse em dinheiro. Porque só os homens faziam atividades que pegavam no dinheiro. Hoje a minha mulher tem o dinheiro dela mesma". (Sr. Ditão - Ivaporunduva)

Fazendo um paralelo entre o que foi referenciado pela irmã Sueli e este depoimento de Ditão, fica claro o motivo pelo qual a atividade artesanal não foi assumida pelos homens. Tal atividade não apresentava condição de ser geradora de ganhos econômicos expressivos e os homens desanimaram, pois viram que esta atividade deveria ser encarada como uma atividade complementar, e portanto, de ganhos econômicos pontuais. Por outro lado as mulheres viram que esta seria uma atividade possível de ser praticada, aliada aos afazeres domésticos e agrícolas já realizados por elas. Tal observação vem de encontro com o que Charkiewicz-Pluta et al.,(1991) observou em seu trabalho com projetos de experiência em reflorestamento e tecnologias alternativas e concluiu que as mulheres que atuam nesses tipos de projetos estão mais voltadas a despenharem as atividades planejadas do que na obtenção de lucros.

Deste modo, pretendeu-se realizar uma análise a respeito da finalidade social dessa atividade com base no preceito de ecodesenvolvimento. Já que este defende como indispensável se considerar, no momento do planejamento e da execução de projetos que visam o alcance de melhorias sociais, as condições sócio-culturais particulares presentes em cada comunidade (Sachs, 1986).

\subsection{0 artesanato como atividade econômica}

Os produtos artesanais de fibra de bananeira produzidos pelos artesãos quilombolas hoje são comercializados em feiras e exposições no mercado interno.

Desde 0 ano de 2000, representantes dos artesãos do Grupo Raízes da Cultura Quilombola e do grupo de artesanato de Ivaporunduva vêm participando desta feira todos os anos, através da exposição dos produtos artesanais produzidos pelas comunidades quilombolas do Vale. Esses produtos são cestarias, feitas com material retirado da mata e objetos 
confeccionados com a fibra de bananeira, sendo estes últimos, aparecido com maior destaque dentre os produtos artesanais quilombolas, em especial das comunidades de Ivaporunduva, André Lopes, Sapatu e Morro Seco.

Há casos também de venda no mercado externo, como a comunidade de Ivaporunduva, que teve bolsas de fibra de bananeira produzidas por artesãos da comunidade compradas para 0 evento da Conferência Mundial Contra o Racismo promovida pela ONU na África do Sul (Garavello, 2001).

\footnotetext{
"O forte do grupo se mobilizar era quando se sabia que tinha um evento que podia vender e aí eles se mobilizavam para fazer o artesanato ..." (Marcio Halla)
}

O trabalho artesanal não tem um ritmo de produção constante, e as artesãs atribuem 0 preço conforme a sua avaliação da peça, isto é, se acha que ficou bem feita, se vai ser vendida em eventos. Há uma relação estreita entre o artesão e sua peça.

Segundo dados obtidos a respeito dos critérios utilizados pelos artesãos para mensurar 0 preço de seus produtos, conclui-se que: ser muito rigoroso na hora de colocar o preço, assim como aprenderam no curso do SEBRAE, dificulta a venda da peça, como exemplifica D. Esperança, artesã de Sapatu,em seu depoimento:

"Nos foi ensinado colocar o valor da peça por hora de trabalho, mas o preço fica caro e ai não sai a peça. Se for para gente ficar olhando nossas peças e ficar passando necessidade não adianta... Eu não aperto no preço, eu faço um preçinho que vejo que eu não fico no prejuízo pelo trabalho" (D. Esperança).

As relações econômicas das comunidades quilombolas de Eldorado são bastante restritas, sendo a venda da banana e a exploração clandestina do palmito juçara as fontes mais expressivas para obtenção de recursos financeiros.

Hoje, o resíduo da bananicultura proporciona para algumas comunidades quilombolas do Vale do Ribeira uma fonte monetária e conforme referido, vêm contribuindo como uma fonte complementar de renda para 0 artesão. Também valoriza o indivíduo através do trabalho, tanto dentro de seu grupo social, como também externo a ele, já que com a venda do artesanato, obtém recurso financeiro - dando-lhe poder de compra. É uma atividade possível de ser realizada 
a baixo custo, tanto no aspecto do acesso a essa matéria prima, quanto da mão-de-obra e instalações.

Conforme pode ser observado na Tabela 7, no caso da comunidade de Ivaporunduva nem um terço dos participantes do curso de 1998 tinham renda própria. Algumas das pessoas capacitadas no curso de 1998 declararam que em média tinham uma renda de R\$93,00/mês, 0 que com relação ao valor do salário mínimo da época que era de $R \$ 130,00$, significa que obtinham menos de um salário/mês.

As ações realizadas pelos diversos colaboradores contribuíram de foram direta e indireta para a atividade artesanal ser o que é hoje na vida de alguns membros das comunidades, uma fonte de renda. Esta teve uma transformação lenta, ou seja, alguns membros dessas comunidades já faziam esteiras, cestos, mas somente para fins utilitários, não havia intenção de coloca-los estes produtos no mercado.

Tabela 7. Quantidade de pessoas que declaram possuir renda e a média mensal destes antes e depois do curso de capacitacão do artesanato com fibra de bananeira de 1998

\begin{tabular}{ccccc}
\hline Comunidades & $\begin{array}{c}\text { Número de pessoas } \\
\text { que participaram do } \\
\text { curso de 1998 }\end{array}$ & $\begin{array}{c}\text { Número de pessoas } \\
\text { que declaram possuir } \\
\text { renda antes do curso }\end{array}$ & $\begin{array}{c}\text { Renda (R\$)média/mês } \\
\text { própria }\end{array}$ & Fonte de renda \\
\hline Ivaporunduva & 23 & 7 & 70,00 & Trabalhos na lavoura \\
André Lopes & 12 & 10 & 120,00 & Venda de banana \\
Sapatu & 18 & 3 & 90,00 & Venda de banana \\
\hline
\end{tabular}

Não há como medir a sustentabilidade econômica da atividade, em virtude da impossibilidade de quantificar a renda individual de cada artesão, antes dessas pessoas terem iniciado com a atividade do artesanato de bananeira. Isso porque as atividades exercidas comumente nas comunidades não são baseadas na produção de capital e sim na segurança alimentar, ou seja, na produção de subsistência, a roça. Somente nos anos 80 a bananicultura se tornou fonte de renda, passando a ser produzida para venda. A artesã de Sapatu, D. Esperança, lembra que: "antigamente os próprios moradores da comunidade davam serviço para outros moradores, e agora não dão mais e só quem tem serviço é pedreiro". Ela ainda faz questão de 
dizer que a única coisa que está sendo procurada além da banana é o artesanato. Isso demonstra que 0 artesanato de fato é uma alternativa para as comunidades estudadas, ou ao menos é vista por alguns como uma possibilidade de obter algum dinheiro, ainda que de modo pontual.

Alguns artesãos relataram que na época em que os cursos de capacitação foram ministrados para as comunidades, a renda individual das pessoas que conseguiam ir para Eldorado fazer algum trabalho remunerado, até mesmo para os fazendeiros da região, era por volta de 30 reais/ mês. Poucas são as outras alternativas disponíveis, a atividade que gera renda para algumas mulheres de Ivaporunduva, além do artesanato de fibra de bananeira, é a produção de doce de banana. Este é vendido na própria comunidade para os visitantes.

"(...) Minha mulher comprou um fogão novo com o dinheiro do artesanato e do doce de banana que vende em casa para os turistas que vêm visitar a comunidade". (Sr. Ditão)

O artesanato com fibra de bananeira ainda é pouco expressivo se for considerado como fonte de renda mensal para os artesãos, mas vale ressaltar que antes da sua introdução, principalmente para as mulheres, não havia atividade que fornecesse a obtenção de algum dinheiro, excluindo as atividades exercidas pelos homens fora da comunidade.

Quando há venda em feira ou a visitação na comunidade de Ivaporunduva, as artesãs tiram de $\mathrm{R} \$ 40,00$ a $\mathrm{R} \$ 100,00$ de lucro.

Para as pessoas que gostam de fazer e trabalham com 0 artesanato de fibra de bananeira, o dinheiro obtido com a venda faz diferença no orçamento familiar, ou seja, antes a produção de banana e os trabalhos fora da comunidade eram as únicas fontes de ganho nessas comunidades e não eram remunerações femininas.

O artesanato de bananeira ocupa a segunda posição, depois da atividade principal, que é a bananicultura. Já a roça de subsistência não gera dinheiro, mas é a garantia de alimento na mesa das famílias. 
De um modo geral, as artesãs não sabem precisar o montante da renda, pois não têm 0 hábito de contabilizá-la. No depoimento de uma artesã de Sapatu pode-se concluir que no ano de 2002, 0 artesanato gerou para ela um lucro de $\mathrm{R} \$ 470,00$ :

"(...) De dois anos para cá eu comecei a anotar o que entrou de dinheiro: no ano de 2002 em janeiro $R \$ 22,00$; fevereiro, $R \$ 21,00$; março e abril, não vendi nada; em maio, $\mathrm{R} \$ 240,00$ (foi o curso que eu fui dar em Nhunguara custeado pelo ITESP e recebi este valor); em junho a renda foi $R \$ 186,00$, em julho nada, agosto nada, setembro $R \$ 148,00$, outubro nada, novembro R\$93,00, dezembro nada..." (D. Sônia - Sapatu)

No ano de 2003, até o mês de agosto o lucro com o artesanato para a mesma artesã, segundo seu depoimento foi de $R \$ 414,00$.

"(...) Em Janeiro vendi - $\mathrm{R} \$ 125,00$; Fevereiro - $\mathrm{R} \$ 20,00$; Março - foi feito artesanato, mas não vendeu; abril - 60,00; maio - nada; junho- 59,00; julho- 125,00; agosto20,00"."(...) trabalho com o artesanato nas horas de folga". (D. Sônia -Sapatu)

Assim, conclui-se que mesmo sendo uma atividade de horas vagas, o lucro que gerou para a artesã é muito expressivo, pois não existe outra atividade que seja realizada em casa e na comunidade, que gere tal lucro.

O dinheiro da venda do artesanato, segundo as artesãs de Sapatu e de André Lopes que são solteiras, é para uso próprio. As artesãs mais velhas e casadas compram "coisas" para a casa com o dinheiro do artesanato. Os depoimentos a seguir fazem referência ao destino dado ao dinheiro obtido com a venda do artesanato. Na Tabela 8 pode-se observar o preço das peças mais produzidas, por serem as mais vendidas atualmente pelos artesãos.

"Fica pra mim o dinheiro da venda do artesananto, mas às vezes a gente compra alguma coisinha que acaba servindo para todos. É mas acaba servindo pra mim mesmo, mas compro as coisinhas minhas". (Sônia - Sapatu)

"O dinheiro do artesanato vai também na despesa da casa. E 0 da minha filha Jorlene dou para ela, para comprar o que quiser, pois agora recebo aposentadoria. A roça é o que segura a despesa da casa". (D. Esperança - Sapatu) 
Tabela 8. Preço das peças mais vendidas pelos artesãos nas comunidades

\begin{tabular}{cccc}
\hline $\begin{array}{c}\text { Tipos de peças } \\
\text { Bolsas }\end{array}$ & $\begin{array}{c}\text { Preço }(R \$) \text { de venda em } \\
\text { Ivaporunduva }\end{array}$ & $\begin{array}{c}\text { Preço }(R \$) \text { de venda em André } \\
\text { Lopes }\end{array}$ & $\begin{array}{c}\text { Preço }(R \$) \text { de venda em } \\
\text { Sapatu }\end{array}$ \\
\hline Jogo americano & 10,00 a 27,00 & 8,00 a 25,00 & 8,00 a 25,00 \\
Pulseiras & 1,00 a 2,00 & 20,00 a 25,00 & 20,00 a 25,00 \\
Caminho de mesa & 20,00 a 25,00 & 1,00 a 2,00 & 1,00 a 2,00 \\
Tapetes & 3,00 a 40,00 & Mínimo 20,00 & Mínimo 20,00 \\
\hline
\end{tabular}

Segundo informação do coordenador do grupo do artesanato de Ivaporunduva, no mês de agosto de 2003, este grupo contava com 19 artesãos, o que significou que a venda média/artesão no referido mês foi de $R \$ 31,00$, com o lucro máximo de $R \$ 27,00 /$ artesão e o mínimo de $R \$ 1,00$. No mês de setembro deste mesmo ano, o lucro máximo com 0 artesanato de bananeira por artesão representou $R \$ 140,00$ e o mínimo $R \$ 8,00$.

A respeito do caixa financeiro do grupo de artesanato de Ivaporunduva, conforme pode-se observar na Tabela 9, após o mês de agosto não foi possível obter dados concretos. Este grupo, quando executa venda na casa do Artesão da comunidade, destina 5\% do preço de cada produto para o fundo do artesanato, que tem por finalidade contribuir para a compra de etiquetas e sacolas plásticas para embalar as peças vendidas pelos artesãos.

Se a venda do artesanato ocorre nas feiras ou eventos, e uma pessoa responsabiliza-se pelas vendas dos produtos, esta pessoa recebe $10 \%$ do valor de cada peça que é vendida.

No caso do Grupo Raízes da Cultura Quilombola, também há um fundo semelhante ao do grupo de Ivaporunduva, que está sendo gerenciado, até o momento, pela artesã Sonia de Sapatu. Segundo ela, no mês de setembro de 2003, havia nele um saldo de $\mathrm{R} \$ 101,00$. 
Tabela 9. Caixa financeiro do fundo do artesanato do grupo de Ivaporunduva no ano 2003

\begin{tabular}{ccccc}
\hline Mês & $\begin{array}{l}n^{\circ} \text { de artesãos } \\
\text { venderam }\end{array}$ & total de venda $(R \$)$ & $\begin{array}{c}\text { média de } \\
\text { renda/artesão }\end{array}$ & valor no fundo (R\$) \\
\hline até agosto & 19 & 573,00 & 28,65 & 80,28 \\
Setembro & 9 & 140,00 & 14,78 & 101,00 \\
Total & 28 & 713,00 & 43,43 & 181,28 \\
\hline
\end{tabular}

O artesanato com fibra de bananeira, sem dúvida, é uma atividade importante como complemento da renda, mas muitos esforços ainda precisam ser feitos. As pessoas mais habilidosas que tinham um artesanato de qualidade, sem dúvida tiveram um aporte de renda maior, mas em 2000 e 2001 poucas foram as pessoas das comunidades que obtiveram ganhos significativos. Atualmente passaram a dar mais importância para 0 artesanato como fonte de renda, não só como uma atividade a ser realizadas nas horas vagas, mas como uma alternativa concreta de complemento financeiro.

Vale ressaltar que o resíduo da bananicultura utilizado como fonte de matéria-prima para a produção de artesanato, impulsionou nas comunidades estudadas as outras formas de artesanatos já existentes, como, esteiras de taboa, cestarias de taquara e de cipós, cujos artesãos vendem, em Eldorado, e no quiosque da Caverna do Diabo para os turistas.

O problema que as artesãs de Sapatu e de André Lopes apontaram com relação ao aspecto econômico, foi o fato da dificuldade de comercialização do artesanato que produzem periodicamente, devido a falta de uma demanda de mercado constante na região.

"Quando vendo não é serviço só de um mês. Sempre tem peças em casa, fico sempre com alguma coisa em casa". (D. Esperança -Sapatu)

"(...) Tem um artesão daqui que não está trabalhando muito com 0 artesanato porque também ficou viúvo e ele tem 3 filhos. E o artesanato não dá dinheiro todo mês fazendo com que ele vá procurar o que dá... Então não dá tempo de trabalhar com a fibra de bananeira, e tem também dia de chuva que não pode trabalhar" (D. Araci Ivaporundava) 
Neste depoimento da artesã D. Araci fica evidente a dificuldade de se padronizar uma produção. Não dá para ter um padrão de peças porque os artesãos têm que lidar com as intempéries e o limites ambientais - fatos que o mercado não leva em consideração já que estão trabalhando com uma matéria prima natural, que é a fibra de bananeira.

Observa-se também que 0 artesanato feito com o cipó e taquara são as peças comumente encontradas no Parque de Jacupiranga, na Caverna do Diabo para venda. Já o artesanato de fibra de bananeira é encontrado esporadicamente, em função da desistência dos artesãos de André Lopes que não confeccionam mais este tipo de artesanato. Segundo os entrevistados dessa comunidade este fato se dá em função da inconstância de venda deste tipo de artesanato, e por ser um material vegetal susceptível a umidade excessiva do ar, tornando as peças confeccionadas com este tipo de fibra natural exposta ao ataque de patógenos como mofo e insetos.

Fora do período das feiras regionais e de exposições em São Paulo, a venda do artesanato depende exclusivamente dos turistas que vão visitar a Caverna do Diabo e a de Santana, em Iporanga. Constata-se um vinculo do comércio do artesanato de bananeira, na região de Eldorado com o turismo para os Parques de Jacupiranga e de Intervales.

"Para mim o artesanato de taquara dá mais financeiramente porque se eu fizer e sair para Eldorado eu vendo tudo, vendo por aqui mesmo na comunidade. Faço peneira e aparado, mas tem gente que faz cestão. Por aqui (Ivaporunduva) não tem mais quem faz cesta. Agora o artesanato da palha da banana é difícil vender em Eldorado, só mesmo prá gente de fora" (D. Aracy - Ivaporunduva)

Salienta-se a necessidade de um local de comercialização destinado à venda dos produtos produzidos nas comunidades quilombolas. Em Eldorado poderia ter um local não apenas para 0 artesanato, mas também para outros produtos. 0 turista que passa pela cidade a caminho dos Parques da região poderia ter como opção comprar produtos e conhecer também outros aspectos culturais dessas comunidades.

Por ser 0 artesanato, um item cultural considerado de utilidade secundária, o que poderia resultar em um aumento significativo de pessoas interessadas por esse tipo de produto seria 0 investimento na propaganda e na qualidade, tanto visual como artística, da peça confeccionada. 
Fica expressivo que o artesanato com fibra de bananeira, mesmo não sendo uma fonte mensal constante, é muito significativo para a "dona de casa", como relata D. Esperança:

"consegui ser aposentada por idade em 2003, mas antes, a fonte de renda própria que eu tinha era somente o artesanato de banana". (D.Esperança, artesã de Sapatu)

"O artesanato é uma fonte de renda para algumas comunidades quilombolas, e hoje o que vemos e Sapatu, com a D. Esperança e a Sônia, André Lopes um pouco e Ivaporunduva. A atividade do artesanato trouxe mudanças para a vida de algumas pessoas sim, como no caso da D. Esperança e da Sônia, que eu posso falar porque não acompanho diretamente esta atividade, mas vejo no caso delas, que hoje são multiplicadores. Elas já foram contratadas pelo ITESP para dar curso de artesanato de fibra de bananeira para outras comunidades e também mais recentemente o SEBRAE também contratou para que elas ensinassem a outras pessoas interessadas da sua própria comunidade" (Técnico do ITESP de Eldorado)

No stand dos quilombos no Revelando São Paulo de 2003, estavam expostas peças do grupo Raízes e de Ivaporunduva. As peças artesanais feitas de fibra de bananeira enviadas pelos artesãos das comunidades quilombolas do Vale foram: tapetes, bolsas, jogo americano, pulserinhas, fundo de panela. Conforme mencionado, esses produtos são os mais vendidos, e portanto, são os que os artesãos mais fazem para levar nas feiras e exposições.

Faltou no stand, diferencial, informando se tratar de artesanato quilombola, pois, haviam outros artesãos, com artesanatos de banana, oriundos dos Municípios de Iguape, Itariri, Pedro de Toledo, Miracatu e Registro, havia, portanto, muita concorrência.

Os preços variavam entre peças iguais, com as mesmas características; por exemplo, bolsas idênticas, tinham preços diferentes. Isto ficou evidente na fala de uma artesã, quando a ela foi perguntado o preço das peças que estava enviando, para a exposição do Revelando.

Segundo relatos de membros da comunidade, após a introdução da atividade turística em Ivaporunduva, a venda dos produtos artesanais de fibra de bananeira se tornou mais constante. Foi observado que em outras comunidades quilombolas vizinhas de Ivaporunduva, nas quais a 
atividade do turismo não está presente, existe mais dificuldade para a comercialização do artesanato confeccionado.

Uma possibilidade de comercialização do artesanato de fibra de bananeira para as comunidades quilombolas são as feiras e exposições turísticas anuais regionais, que ocorrem em algumas cidades do Vale, às quais as comunidades quilombolas são convidadas a exporem seus produtos artesanais. Há uma perspectiva altamente promissora de comercialização local da produção do artesanato com fibra de bananeira que é através do ecoturismo na região. Essa atividade está sendo muito almejada nas comunidades quilombolas, como forma de geração de renda e valorização da cultura local.

Foi observado até o presente momento, que estas formas de comercialização não são suficientes para motivar os artesãos a trabalharem na confecção de produtos artesanais, utilizando com regularidade o resíduo da agricultura bananeira.

\subsubsection{0 artesanato e o turismo na comunidade de Ivaporunduva}

$\mathrm{O}$ artesanato com fibra de bananeira além de ter proporcionado uma alternativa de renda, também se tornou um atrativo turístico para algumas localidades do Vale.

No trecho da estrada que liga Eldorado aos Parques (Jacupiranga, PETAR e Intervales) onde estão localizadas as comunidades de André Lopes e Sapatu, os artesãos expõem seus produtos artesanais em barraquinhas na beira da estrada, onde há maior circulação de visitantes, e alguns desses param para comprá-los. Desde 2000, os artesãos das duas comunidades referidas acima, já comercializavam seus artesanatos neste esquema (Figura 25). 


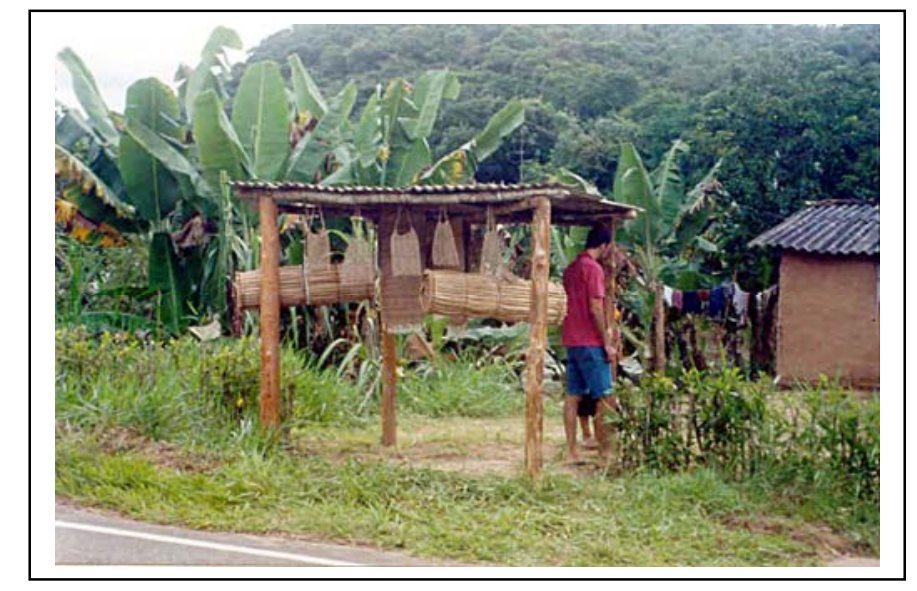

Figura 25. Barraca na beira da estrada de acesso à Caverna do Diabo, em frente da casa de uma artesã. Exposição e venda do artesanato de bananeira e esteiras feitas de taboa

Com o aumento do turismo para os Parques da região, consequentemente aumentou 0 número de pessoas interessadas no artesanato local. Tal motivo resultou no aumento do número de pessoas das comunidades, principalmente os mais jovens que começaram a coletar indiscriminadamente da mata, segundo relatou o Sr. Marcio Halla, o cipó imbé e o timbopeva.

"(...) os mais jovens mesmo sabendo e sendo alertados de como manejar os recursos utilizados para a confecção do artesanato tradicional, deixaram de respeitar porque tinham demanda, vendiam para 0 turismo. Pois eles disseram também que tem a lua certa para tirar. Não pode puxar porque vêm a mãe e cortado no cordão, até quebrar não pode tirar o verde só o "madeiro". É necessário estudar o manejo do cipó imbé e timbopeva, é importante sim, precisa de pesquisas nessa área (...). Nunca aconteceu de artesãos que já trabalhavam com cipó deixarem para trabalhar com a fibra de banana, não aconteceu isso não. As pessoas que já faziam cestarias bem forte e tinham escoamento e que vendiam pelo turismo continuaram fazendo e vendendo, na estrada, na Caverna do Diabo" (Sr. Marcio Halla).

Em 2001, a comunidade de Ivaporunduva iniciou 0 agendamento de visitação de alunos de escolas públicas da região, e de escolas particulares que vêm de São Paulo, através da Associação a fim de tornar planejada essa demanda. Segundo o coordenador do grupo do artesanato de Ivaporunduva, a visitação ao quilombo se tornou uma boa oportunidade para se comercializar 0 artesanato. E de certa forma também tem motivado os artesãos a 
confeccionarem peças com a fibra de bananeira, já que nessas ocasiões há maior possibilidade de venda de seus produtos.

"(...) 0 turismo ainda não atende todo mundo. A gente está fazendo um planejamento para quando terminar a pousada, aumentar a visitação e distribuir de uma forma mais proporcional entre as famílias que se interessam por este trabalho" (Paulo Ivaporunduva)

Fica claro na fala a seguir, que o turismo na comunidade, é aliado do artesanato e motivador da produção.

"(...) o pessoal está fazendo e vendendo, em função das visitas de turismo na comunidade e algumas feiras. A gente esta conseguindo fazer e vender (...). Outras comunidades que não têm a atividade do turismo, tem mais dificuldade para comercialização, tem algumas feiras, como a Revelando São Paulo, têm algumas cidades que fazem umas festas e nos convidam para estar apresentando nosso artesanato, mas isso não é suficiente para estar motivando legal as pessoas para fazerem artesanato". (Paulo - Ivaporunduva)

Essa atividade turística proporciona renda aos agentes locais, ao mesmo tempo em que é uma oportunidade para os artesãos da comunidade venderem seus produtos artesanais.

Devido à introdução da atividade turística em Ivaporunduva, a venda dos produtos artesanais de fibra de bananeira se tornou mais constante.

"(...) as comunidades sempre viram os espaços turísticos como uma possibilidade para o comércio, sempre pensavam nisso. O turismo comprando 0 artesanato e 0 artesanato chamando o turismo". (Sr. Márcio Halla)

Quando as artesãs foram questionadas a respeito do melhor modo para a comercialização, e qual a melhor estratégia para venda do artesanato de bananeira, todas apontaram os eventos regionais e a época de férias, em função do turismo nos Parques da região. 
As artesãs de Sapatu e André Lopes, relataram que a época do ano que vendem mais o artesanato, é no final do ano, para a llha Verão, festa que ocorre na llha Comprida, município de Iguape, e nas férias de julho, quando ocorre elevação do turismo na região de Eldorado.

O turismo na região do Vale do Ribeira tem se apresentado como uma alternativa, mas que necessita de investimentos, e capacitação da mão de obra local.

Fomentar a produção sazonal do artesanato com a fibra de bananeira, como uma alternativa produtiva complementar às várias atividades que são realizadas nas comunidades estudadas, ou seja, a pluriatividade: a produção de banana, o roçado, a confecção de doce de banana e outros trabalhos manuais, talvez, seja o caminho da sustentabilidade para essa atividade.

Além de gerar uma renda financeira aos envolvidos na atividade artesanal com fibra de bananeira, esta também despertou a reflexão dos artesãos para a questão do aproveitamento de um resíduo agrícola considerado sem valor. Hoje o resíduo da bananicultura é considerado matéria-prima passiva de ser transformada em um produto artesanal gerador de renda. 


\section{CONSIDERAÇÕES FINAIS}

Todos os esforços, pelo e para o desenvolvimento rural, tem como objetivo final, melhorar o nível de vida da população beneficiária. Isto implica em buscar a socialização de conhecimentos e saberes entre comunidades, pesquisadores, políticos e técnicos em geral, de modo a construir saberes sócio-ambientais, necessários para consolidar um novo paradigma de desenvolvimento rural, que considere as dimensões: ecológica, social, econômica, cultural, política e ética da sustentabilidade planetária.

Sendo o Ecodesenvolvimento um conceito teórico estratégico de desenvolvimento, que busca estabelecer uma relação de harmonia entre o homem e a natureza, a premissa fundamental é promover a autonomia das populações, estimular a reflexão e a experimentação participativa de formas de crescimento econômico que priorizem o potencial dos recursos naturais e sociais de cada locus (Boff, 1996; Sachs, 1980; Vieira, 2001). Tal conceito foi adotado como referencial teórico deste trabalho.

Agrupando-se os dados obtidos na pesquisa de campo em três categorias: a ambiental; a sócio-cultural e a econômica, efetuou-se uma análise com base nos critérios do Ecodesenvolvimento: a). Prioridade ao alcance de finalidades sociais; b). Prudência ecológica; c). Valorização da participação e autonomia e d). Viabilidade econômica.

No contexto das comunidades quilombolas estudadas, pôde-se verificar nesta dissertação, que: (I) o Projeto de Aproveitamento do Resíduo da Bananicultura no Vale do Ribeira, através dos cursos de capacitação voltados ao uso do resíduo da bananicultura como matéria prima para a produção artesanal, parece ter contribuído significativamente para a valorização de uma atividade que muitas pessoas das comunidades quilombolas já tinham por 
vocação, que é a expressão artesanal; (II) a atividade artesanal com fibra de bananeira é uma das principais fontes de renda para os artesãos das comunidades quilombolas de Ivaprunduva, Sapatu e André Lopes; (III) é uma atividade onde se destaca o envolvimento do gênero feminino portando, um fator potencial dessa atividade é ter proporcionado o reconhecimento social interno e externo da mulher quilombola, sem descaracterizar o papel tradicional desta junto ao núcleo familiar; (IV) é uma atividade que se apresenta compatível socialmente com a realidade local e vêm promovendo a melhoria na qualidade de vida das artesãs envolvidas e a valorização da criatividade pessoal.

Conclui-se que não há modelos acabados de ecodesenvolvimento, as estratégias viáveis diferem de região para região, de comunidade para comunidade, como pode ser visto com relação às três comunidades estudadas.

Do prisma sócio-cultural defendido pelo ecodesenvolvimento, pode-se concluir que especialmente na comunidade de Ivaporunduva, devido à organização interna do grupo de artesãos, esta atividade teve um crescimento expressivo desde sua introdução na comunidade até os dias atuais. Comparando a atividade entre as três comunidades, a de Ivaporunduva é a que apresenta hoje maior êxito com relação ao aspecto econômico dessa atividade, em função do turismo local, com a visitação das escolas na comunidade. Este proporciona um mercado para venda do artesanato com maior constância, o que estimula que mais artesãos produzam e vendam seus produtos. Já as comunidades de Sapatu e André Lopes têm um mercado incerto para venda, desestimulando os artesãos a manterem a atividade de produção de artesanato com fibra de bananeira. As artesãs que fazem o artesanato nessas duas comunidades são as que têm produzido peças de melhor qualidade, isto é, melhor acabamento e matéria prima, sem problema fitossanitário. Portanto têm conseguido comercializar nas feiras e exposições.

O fator limitante com relação a esta atividade é a forma de comercialização praticada, a qual não é suficiente para motivar outras pessoas a trabalharem na confecção de produtos artesanais utilizando o resíduo da agricultura bananeira.

Do ponto de vista ambiental esta atividade não causa dano a conservação do ecossistema e dos recursos florestais locais. Assim como não polui a meio ambiente, não apresentando riscos à saúde e não interferindo no ciclo ecológico e estimulando a reciclagem dos resíduos agrícolas, isto é uma tecnologia limpa é utilizada na produção deste tipo de artesanato. 
Portanto conclui-se que tal atividade não provocou mudanças ambientais que podem ser consideradas negativas, e que esta se encontra de acordo com 0 proposto pelo ecodesenvolvimento, o aproveitamento dos recursos locais de forma equilibrada. Ou seja, é uma alternativa não só positiva ambientalmente, como também social. E que têm gradativamente se mostrado também expressiva como opção de complemento da renda familiar para os artesãos. Tais observações a respeito da atividade artesanal com fibra de bananeira vêm de encontro com o pensamento defendido por Graziano da Silva (1996), ou seja, que a atividade artesanal pode ser realizada em conjunto e em complementaridade à agricultura de subsistência, em busca de outras fontes de renda que sejam viáveis e que elevem a "qualidade de vida" local.

Pode-se fazer referência à atividade artesanal com fibra de bananeira como uma alternativa de desenvolvimento, a qual visa de modo interdisciplinar contemplar as dimensões: sócio-cultural, econômica e ambiental, conforme novas tendências globais com vistas ao alcance do ecodesenvolvimento com base na produção e consumo consciente. Portanto, pode se afirmar que a atividade do artesanato com fibra de bananeira está em consonância com os preceitos estratégicos do ecodesenvolvimento.

Deste modo é possível afirmar que um trabalho local de intervenção como esse, ajuda a demonstrar que é possível adotar as estratégias de planejamento defendidas pelo ecodesenvolvimento num contexto micro, como um exercício de mudança da sociedade. Quando se pensa em proposta de projeto de desenvolvimento para zonas rurais, deve-se, sempre, considerar as peculiaridades da população, e o potencial natural dos recursos existentes, como foi tratado o uso do resíduo da bananicultura, já que é esta, a atividade agrícola principal da região do Vale do Ribeira. E a ação da ESALQ, como geradora de conhecimento, no caso do desenvolvimento da técnica para uso dos resíduos da bananicultura também é vista como positiva.

Quanto à atuação dos colaboradores externos, ainda demonstra-se necessária, refletindo uma certa falta de autonomia por parte dos artesãos. Ainda hoje, é necessária a intervenção dos colaboradores externos, na questão da venda e também na organização e na qualidade das peças artesanais produzidas pelos artesãos, sendo estes, os aspectos ainda limitantes da atividade, observados ao longo deste trabalho. 
ANEXOS 
ANEXO A

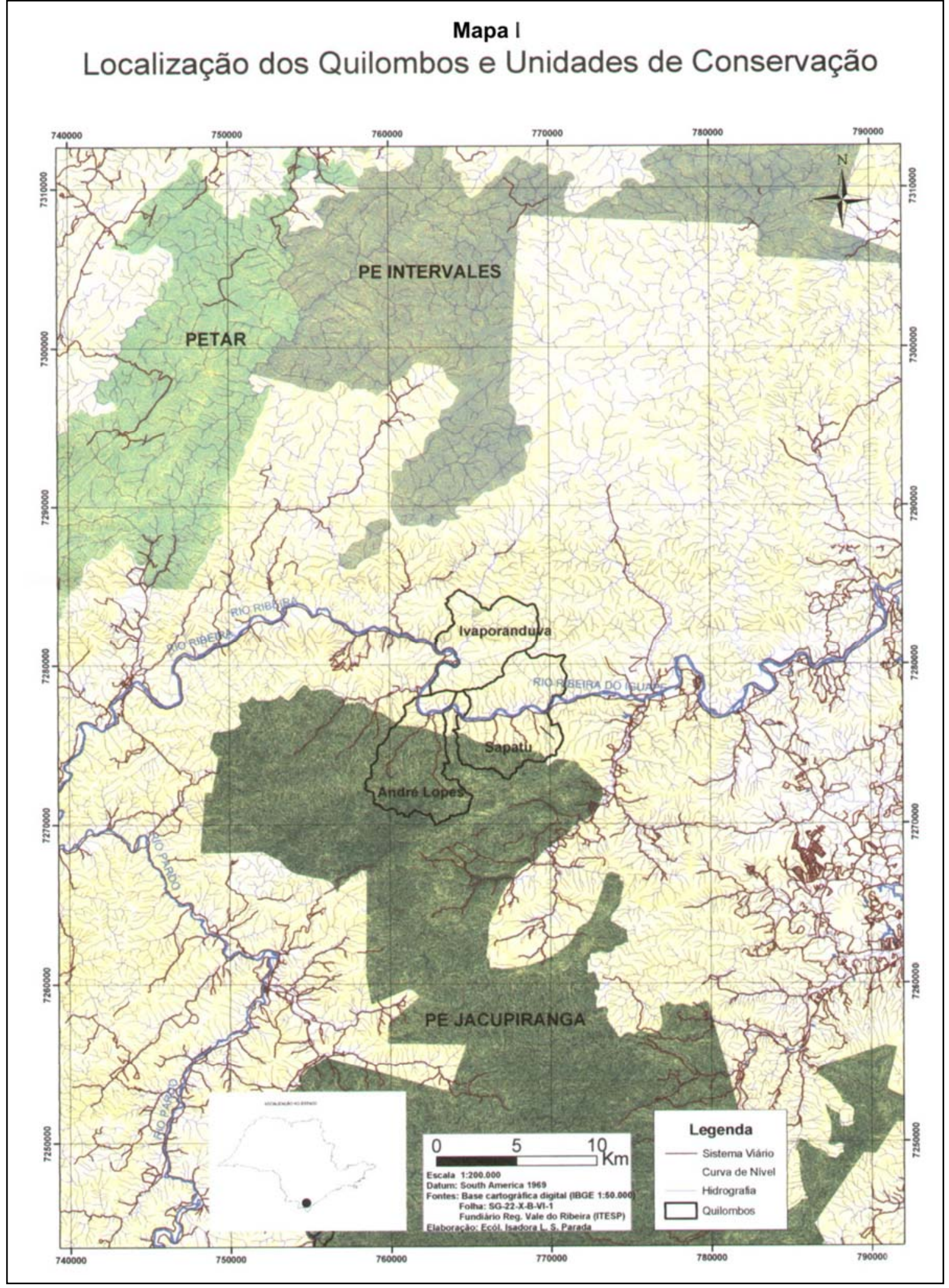


ANEXO B

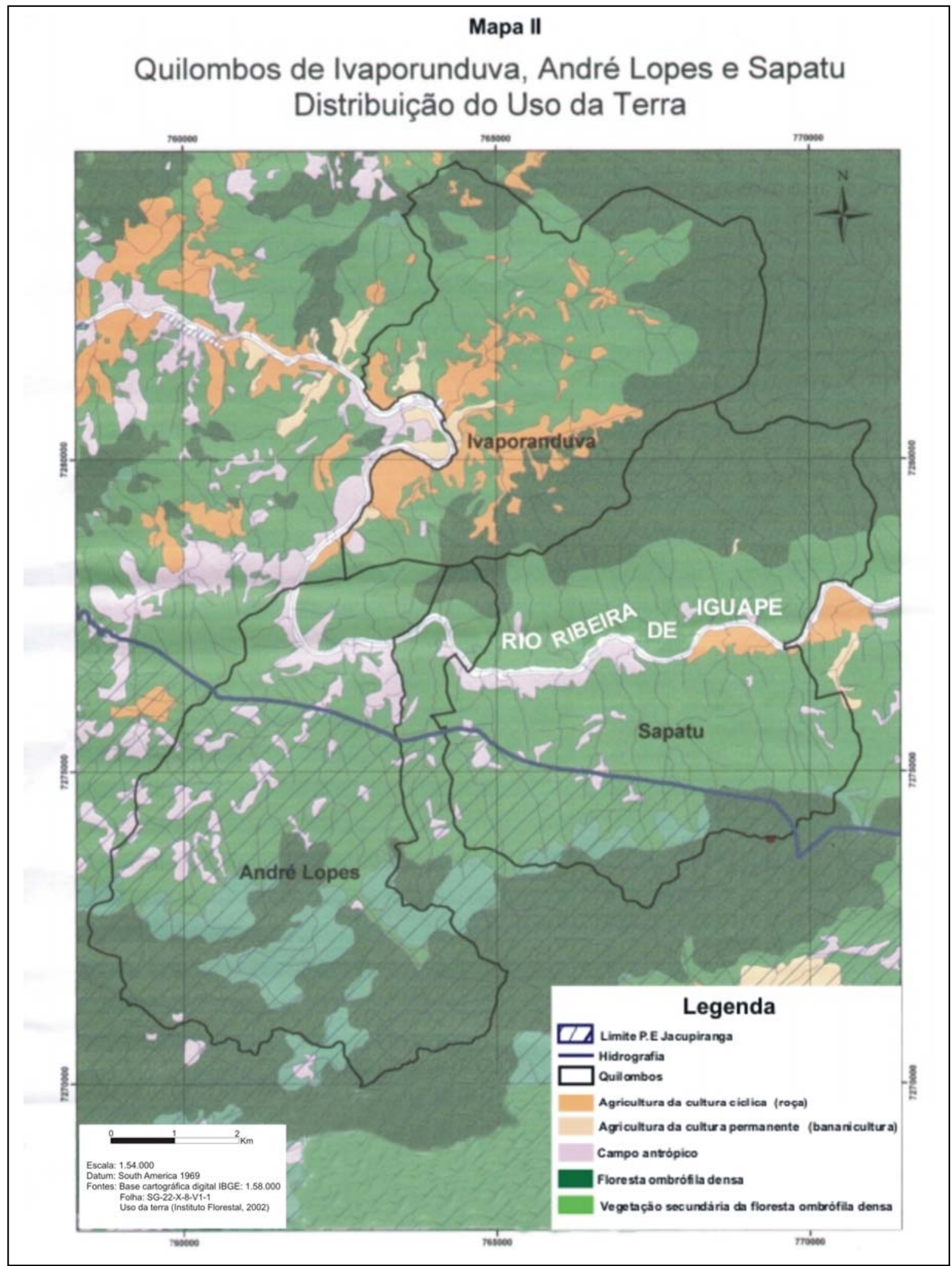




\section{REFERÊNCIAS BIBLIOGRÁFICAS}

ADAMS, C. Caiçaras na Mata Atlântica: pesquisa científica versus planejamento e gestão ambiental. São Paulo: Annablume/FAPESP, 2000. 366p.

ALBUQUERQUE, J. de L., ARAÚJO, J. de F. Administração dos recursos naturais: considerações críticas sobre a manutenção da sustentabilidade. In: ENCONTRO ANUAL DA ASSOCIAÇÃO NACIONAL DOS CURSOS DE PÓS-GRADUAÇÃO EM ADMINISTRAÇÃO. 19, João Pessoa, 1995. Anais. São Paulo: ANPAD, 1995, p. 5-14.

ALMEIDA, J.R.; MORAES, F.E.; SOUZA, J.M.;MALHEIROS, T.M. Planejamento Ambiental: caminho para a participação popular e gestão ambiental para nosso futuro comum, uma necessidade, um desafio. Rio de Janeiro: Biblioteca Estácio de Sá, 1999. 154p.

ANDRADE, T. (org). Quilombos em São Paulo: tradições, direitos e lutas. São Paulo: IMESP, 1997. 102p

BECKER, B.K. A Amazônia Pós ECO-92: por um desenvolvimento regional responsável. In: BURSZTYN, M. (org.). Para pensar o desenvolvimento sustentável. São Paulo: Brasiliense, 1994. 129-143p. 
BOFF, L. Ecologia, mundialização espiritualidade. 2.ed. São Paulo: Ática, 1996.180p.

BOFF, L. Saber Cuidar: ética do humano - compaixão pela terra. 8.ed. Petrópolis,RJ: Vozes,2002. 199p.

BORN,R. H.; TALOCCHI, S. Conservação, desenvolvimento e serviços ambientais em área da Mata Atlântica: o caso do Vale do Ribeira (São Paulo). In: BORN, H. R.; TALOCCHI, S. Proteção do capital social e ecológico: por meio de compensação por serviços ambientais (CSA). São Paulo: Peirópolis; São Lourenço da Serra, SP: Vitae Civilis, 2002. p.107-128.

BRÜSEKE, F. J. Desestruturação e desenvolvimento. In: L. da C. FERREIRA, L. da C., VIOLA, E. (org.). Incertezas de sustentabilidade na globalização. Campinas: Ed. da Unicamp, 1996. $152 p$

CAPORAL, F. R.; COSTABEBER, J. A. Agroecologia e extensão Rural: contribuições para a promoção do desenvolvimento rural sustentável. Brasília: MDA/SAF/DATER - IICA, 2004. $165 p$.

CARRIL, L.F.B. Terras de negros no vale do Ribeira: Territorialidade e resistência. São Paulo,1995. 252p Dissertação (Mestrado) - Faculdade de Filosofia, Ciências e Letras, Universidade de São Paulo.

CAVALCANTI, C. O pensamento de Ignacy Sachs e a economia ecológica. In: VIEIRA, P.F.(org.) Desenvolvimento e meio ambiente no Brasil: A contribuição de Ignacy Sachs. Porto Alegre: Pallotti, Florianópolis: APED, 1998. p.173 - 193.

CHARKIEWICZ-PLUTA, E.; HAUSLER, S.; BRAIDOTTI R. ; WIERINGA, S. Project on Women, The Environment an Sustainable Development. Holanda: Den Haag, 1991.123p. 
CHAVES, L. I. Parâmetros ambientais no planejamento de móveis seriados de madeira de acordo com relatos de designers. Curitiba: CEFET-PR, 2003.136p.

COMISSÃO MUNDIAL SOBRE MEIO AMBIENTE E DESENVOLVIMENTO: Nosso Futuro Comum. Rio de Janeiro: FGV,1992.430p.

DA MATTA, R. A casa e a rua: Espaço, cidadania, mulher e morte no Brasil. São Paulo: Ed. Brasiliense, 1985. 140p.

DIEGUES, A. C.(org). Etnoconservação - novos rumos para a conservação da natureza. São Paulo: Hucitec - NuPaub/USP, 2000. 276p.

ESCOBAR, A. El desarrollo sostenible: diálogo de discursos. Ecología Política. n. 9, p.7-25, jun. 1995.

ESTEVA, G. Development. In: SACHS, W. (Ed.). The development dictionary: a guide to knowledge as power. London: Zed Books, 1996. 85p

ELLIOT, J. A. An introduction to sustanable development. Great Britain: Biddles, 1999. 215p.

FIÚZA, A. L. C. A mulher e 0 ambientalismo. Estudos Sociedade e Agricultura, n. 9, p.178-189, Out. 1997.

FUNDAÇÃO FLORESTAL. Repovoamento do palmiteiro Juçara (Euterpe edulis mart.) no entorno do Parque Estadual Intervales. http://www.fflorestal.sp.br (26 jan. 2005).

FUNDAÇÃO SEADE. SISTEMA ESTADUAL DE ANÁLISE DE DADOS. Anuário Estatístico do Estado de São Paulo, 2005. http://www.seade.gov.br/produtos/anuario/index.htm (20 jan. 2005). 
GARAVELLO,M.E.P.E.Projeto Banana-Artesanato: parcerias e inovação na geração de renda, p.21-28 . In: CALDERON, A.; SAMPAIO, H. (Org). Universidade Solidária e Extensão Universitária: projetos de ação comunitária em universidades brasileiras. São Paulo: Olho D'água, 2002. 292p

GARAVELLO,M.E.P.E.; MOLINA, S.M.G.; STURION, G.L. Aproveitamento de Resíduos da Agroindústria da Banana do Vale do Ribeira, SP, Brasil. In: (compact disc) JORNADAS IBERO-AMERICANAS SOBRE APROVECHAMIENTO DE DESECHOS DE LA AGROINDÚSTRIA BANANEIRA, $1^{\circ}$, Guatemala, 2001. Anais Guatemala: Programa CYTED - Ciência y Tecnologia para el Desarrolho, 2001. 15p.

GODOY, A.S. Pesquisa Qualitativa: tipos fundamentais. Revista de Administração de Empresas, v. 35, p. 20-29, Mai/Jun. 1995.

GRAZIANO DA SILVA, J. O Novo rural brasileiro. Anais da SOBER, vol.1, p.71-90, 1996

HAWKEN, P; LOVINS, A; LOVINS,L. H. Capitalismo natural:criando a próxima revolução industrial. São Paulo: Cultrix, 1999. 130p.

INSTITUTO DE TERRAS DO ESTADO DE SÃO PAULO (ITESP). Terra e cidadãos São Paulo. Negros do Ribeira: Reconhecimento étnico e conquista do território. Cadernos ITESP, n. 3. 160p. nov, 1998a.

INSTITUTO DE TERRAS DO ESTADO DE SÃO PAULO (ITESP). Terra e cidadãos: Aspectos da ação de regularização fundiária no Estado de São Paulo. Cadernos ITESP, n. 4.p.75-76, $1998 b$.

INSTITUTO DE TERRAS DO ESTADO DE SÃO PAULO (ITESP). Remanescentes da comunidade de quilombo de Ivaporunduva, no Vale do Ribeira -SP.1998c. 102p.(Relatório Técnico - Científico) 
INSTITUTO DE TERRAS DO ESTADO DE SÃO PAULO (ITESP). Fatos da Terra. v.1, n.3, p.1115, set./out. 2000.

INSTITUTO DE TERRAS DO ESTADO DE SÃO PAULO (ITESP). A comunidade de quilombo do Sapatu, no município de Eldorado, no Vale do Ribeira -SP, 2004. 45p. (Relatório Técnico)

INSTITUTO DE TERRAS DO ESTADO DE SÃO PAULO (ITESP) http://www.ITESP.sp.gov.br/acproges/quilombos/numeros.htm. (03 mar. 2005).

INSTITUTO DA CIDADANIA. Uma proposta de desenvolvimento sustentável para o Vale do Ribeira. São Paulo, 1996. 45p.

INSTITUTO SOCIOAMBIENTAL (ISA). Sistema de informação geográfica do vale do Ribeira. São Paulo: Instituto Socioambiental, 1997. 23p.

INSTITUTO SOCIOAMBIENTAL (ISA). Diagnóstico socioambiental do Vale do Ribeira. São Paulo: Instituto Socioambiental, 1998.63p.

INSTITUTO SOCIOAMBIENTAL (ISA). Tijuco Alto: Saiba porque ela não interessa ao Vale Ribeira. São Paulo : Instituto Socioambiental, nov.,2002. 23p.

INSTITUTO SOCIOAMBIENTAL (ISA). http://www.socioambiental.org. (12 mai. 2004).

LAYRARGUES, P. P. Do ecodesenvolvimento ao desenvolvimento sustentável: evolução de um conceito? Proposta. n. 71, p.25-32, 1997.

LEFF, E. Saber ambiental: sustentabilidade, racionalidade, complexidade, poder. Petrópolis, RJ: Vozes, 2001. 263p 
LEFF, E. Epistemologia ambiental. 2.ed.,São Paulo: Cortez, 2002. 239p.

MARTINEZ, M.C. A ação governamental e a resistência camponesa no Vale do Ribeira. São Paulo, 1995. 248p. Dissertação (Mestrado) - Faculdade e Filosofia, Ciências e Letras, Universidade de São Paulo.

MINAYO, M.C.S.(org). Pesquisa social: teoria, método e criatividade. 18.ed. Petrópolis: Vozes, 2001. $80 p$

MIRALES, R.A Identidade quilombola das comunidades Pedro Cubas e Ivaporunduva. São Paulo, 1998.180p. Dissertação (Mestrado) - Pontifícia Universidade Católica.

MORAES, E.C.A construção do conhecimento integrado diante do desafio ambiental: uma estratégia educacional. In: NOAL, F.de.O. (org.). Tendências da educação ambiental brasileira. Santa Cruz do Sul: EDUNISC, 1998. p. 35-54.

MOREIRA, R.J. Críticas ambientais à revolução Verde. Revista Estudos Sociedade e Agricultura. n.15,. p. 39-52. out. 2000.

MORETTO, C.F. As Múltiplas faces da informalidade. In TEDESCO, J.C.; CAMPOS, G.L.R. (org.). Economia solidária e reestruturação produtiva: (sobre) vivências no mundo do trabalho. Passo Fundo:UPF, 2001. p.99 -124.

MORIN, E. Os sete saberes necessários à educação do futuro. São Paulo: UNESCO, 2000. $118 p$.

PETRONE, P. A Baixada do Ribeira: Estudos de Geografia Humana. n. 283,p.5-7 1966. 
QUEIROZ, R. S. Essa Terra é santa, essa terra é nossa: A comunidade Quilombola de Ivaporunduva e o direito de propriedade. In: ANDRADE, T. (Org). Quilombos em São Paulo: tradições, direitos e lutas. São Paulo: IMESP/ITESP, 1997. p.25-30.

RESENDE, R.U. As regras do jogo: legislação florestal e desenvolvimento sustentável no Vale do Ribeira. São Paulo: Annablume/FAPESP, 2002. 198p.

RIBEIRO, W.C. Desenvolvimento sustentável e segurança ambiental global. Revista Bibliográfica de Geografía Y Ciencias Sociales. n. 312, p.32-40. sept., 2001.

SACHS, I Stratégies de l'écodéveloppement. Paris: Editions Economie et Humanisme/LES. 1980.140p

SACHS, I Ecodesarrollo. Desarrollo sin destrucción. México: EL Colegio de México. 1982.152p

SACHS, I Ecodesenvolvimento: crescer sem destruir. São Paulo: Vértice, 1986. 196p

SACHS, I. Recursos, emprego e financiamento do desenvolvimento: produzir sem destruir: 0 caso do Brasil. In: Relatório de introdução ao Seminário Internacional organizado pelo CENDEC. Brasília: CENDEC, out. 1988. 45p.

SACHS, I. Entrevista. Cadernos do Terceiro Mundo. v. 16, n.160, p.16-21, 1993.

SACHS, I. Estratégias de transição para o século XXI. In: BURSZTYN, M. (org.). Para 0 desenvolvimento sustentável. 2.ed. São Paulo: Brasiliense, 1994.p.29-56.

SACHS, I. Caminhos para o desenvolvimento sustentável. Rio de Janeiro: Garamond, 2000, $96 p$. 
SANTOS, B. S. (Org.) Reinventar a emancipação social: novos manifestos. Produzir para viver: os caminhos da produção não capitalista. Rio de Janeiro: Civilização Brasileira, 2002. v.2, $514 p$.

SANCHES, R.A. Caiçaras e a estação ecológica de Jureia-Itatins (Litoral Sul-São Paulo): uma abordagem etnográfica e ecológica para o estudo da relação homem - meio ambiente. São Paulo. 1997. 209p. Dissertação (Mestrado) - Instituto de Biociências, Universidade de São Paulo.

SEVILLAGUZMÁN, E.; GUZMÁN CASADO, G.; ALONSO MIELGO,A. Agroecologia y desarrolo rual sostenible. Córdoba: ISEC-ETSIAM, Universidad de Córdoba, Espana, 1999. 386p

SIMÃO, C.G. Áreas cultivadas na comunidade cachoeira do Guilherme, na Estação Ecológica Juréia-Itatins, SP. Piracicaba, 2003.133p. Dissertação (Mestrado) - Escola Superior de Agricultura "Luiz de Queiroz", Universidade de São Paulo.

SOARES,F. Quando o eco-design é mais que verde. Estudos em Design, v.7, n.3, p. 12-18, dez,1999.

SODRZEIESKI, A. E. Relatório CATI. Iporanga: CATI, 1998. 69p.

STUCCHI, D. (coord.). Laudo Antropológico: Comunidades negras de Ivaporunduva, São Pedro, Pedro Cubas, Sapatu, Nhunguara, André Lopes, Maria Rosa e Pilões. São Paulo: Ministério Público Federal, 1998. 62p.

TAYLOR, S.J; BOGDON,R. Introducion a los metodos cualitativos de investigacion:la búsqueda de significados. Barcelona: Paidos,1987. 22p.

TEDESCO, J. C. Economia solidária e reestruturação produtiva: (sobre) vivências no mundo do trabalho. Passo Fundo:UPF, 2001.196p. 
TODESCHINI, R. (coord). A Comercialização na Economia Solidária. São Paulo. CUT/SEBRAE/ ADS - Agência de Desenvolvimento Solidário, 2002. 163 p.

VIEIRA, P.F. Meio ambiente, desenvolvimento e planejamento. In: VIOLA, E.J. (org.). Meio Ambiente desenvolvimento e cidadania: desafios para as ciências sociais. Florianópolis: Editora da UFSC, 2001. p.45-97.

VIOLA, E.J.; LEIS, H. R. O ambientalismo multissetorial no Brasil para além da Rio - 92: O desafio de uma estratégia globalista viável. Meio ambiente, desenvolvimento e planejamento. In: VIOLA, E.J. (org.). Meio Ambiente, desenvolvimento e cidadania: desafios para as ciências sociais. Florianópolis: Editora da UFSC, 2001. p.134 -160. 